UNITED STATES

DEPARTMENT OF THE INTERIOR

GEOLOGICAL SURVEY

OCCURRENCE AND USE OF GROUND WATER IN THE VENICE-ENGLEWOOD

AREA, SARASOTA AND CHARLOTTE COUNTIES, FLORIDA

By H. Sutcliffe, Jr. and T. H. Thompson

Open-File Report $82-700$

Prepared in cooperation with the

ENGLEWOOD WATER DISTRICT and the

FLORIDA DEPARTMENT OF NATURAL RESOURCES

Tallahassee, Florida 
UNITED STATES DEPARTMENT OF THE INTERIOR

JAMES G. WATT, Secretary

GEOLOGICAL SURVEY

Dallas L. Peck, Director

For additional information write to:

District Chief U.S. Geological Survey Suite 3015, Hobbs Federal B1dg. 227 North Bronough Street Tallahassee, Florida 32301
Copies of this report can be purchased from:

Open-File Services Section U.S. Geological Survey Box 25425, Federal Center Denver, Colorado 80225 (Telephone: (303) 234-5888) 


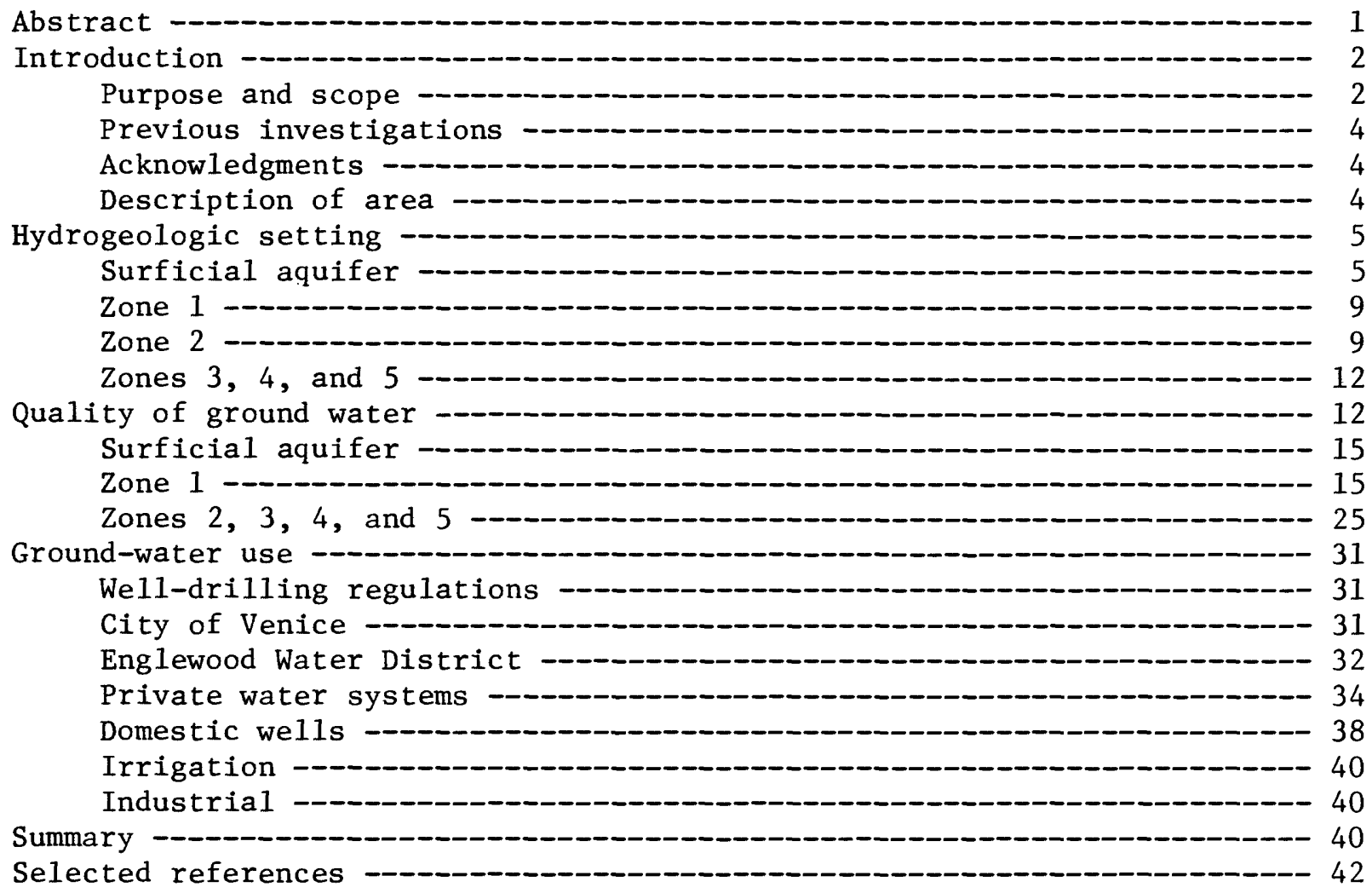

\section{ILLUSTRATIONS}

Figure 1. Map showing the locations of the Venice-Englewood area and public water-supply systems -- 3

2. Diagram of generalized lithologic columns of the surficial aquifer and zones 1 and 2

3. Graph showing rainfall at Englewood, daily pumpage from the Englewood well field, and hydrograph of water level in well 6 in the Englewood well field, 1975

4. Map showing depth to top of the Hawthorn Formation --------- 11

5. Map showing potentiometric surface of the Floridan aquifer, September 1976 --_-_-_-_-_- 13

6. Map showing potentiometric surface of the Floridan aquifer, May 1977 -_-_-_-_-_- 14

7. Map showing areas where chloride concentration in water in the surficial aquifer exceeds 250 milligrams per liter ----- 16

8. Map showing areas where chloride concentration in water from zone 1 exceeds 250 milligrams per liter 


\section{ILLUSTRATIONS - Continued}

Page

Figure 9. Map showing areas where specific conductance of water from zone 1 exceeds 1,000 micromhos per centimeter at $25^{\circ}$ Celsius

10. Map of an area east of Venice showing specific conductance of water from selected wells less than 200 feet deep -_-_-_-_ 20

11. Map showing areas where chloride concentration in water from zone 2 exceeds 250 milligrams per liter

12. Map showing areas where sulfate concentration in water from zone 2 exceeds 250 milligrams per liter -_- 27

13. Map of an area east of Venice showing specific conductance and chloride concentration of water from selected sampling points in zone 2 and deeper zones, 1977

14. Map showing locations of production, observation, and test wells of the city of Venice

15. Graph showing average daily pumpage, by months, by the city of Venice, 1963-75 33

16. Hydrograph of water level in observation well 35 near the city of Venice well field, 1963-75

17. Graph showing average daily pumpage, by months, by the Englewood Water District, 1964-75

18. Map showing locations of production wells and selected observation wells of the Englewood Water District -

19. Map showing locations of test wells near Englewood -

20. Hydrographs of water levels in observation we1ls TW6, TW8, and TW14 of the Englewood Water District, 1971-75

21. Map showing locations of Venice Gardens Utilities well fields 1 and 2 and Venice East well field

\section{TABLES}

Table 1. Water-yielding zones in the Venice-Englewood area - - 6

2. Hydrologic and water-quality data from Venice test wel1 1 and Englewood Water District test well RO-1

3. Chemical analyses of water from Englewood Water District well 20

4. Chemical analyses of water from test wells of the Englewood Water District

5. Hydrologic data and chemical analyses of water from the city of Venice test wells 


\section{TABLES - Continued}

Page

Table 6. Hydrologic data and chemical analyses of water from wells of the city of Venice that supply the reverse-osmosis (RO) desalination plant

7. Analyses of raw and treated water from selected water treatment plants in the Venice-Englewood area - 43

8. Records of wells that supply water-treatment plants, VeniceEnglewood area

\section{ABBREVIATIONS AND CONVERSION FACTORS}

Factors for converting inch-pound units to International System of units (SI) and abbreviation of units

\section{Multiply}

inch (in)

foot ( $\mathrm{ft}$ )

mile (mi)

square mile $\left(\mathrm{mi}^{2}\right)$

foot per mile ( $\mathrm{ft} / \mathrm{mi}$ )

gallon (gal)

gallon per minute (gal/min)

million gallons per day

(Mgal/d)

foot per day ( $f t / d)$

square foot per day $\left(\mathrm{ft}^{2} / \mathrm{d}\right.$ )

micromho per centimeter at

$25^{\circ}$ Celsius (umho/cm at $25^{\circ} \mathrm{C}$ )
By

25.4

0.305

1.609

2.59

0.1896

3.785

0.0631

0.04381

0.305

0.0929

1.000
To obtain

millimeter $(\mathrm{mm})$

meter (m)

kilometer $(\mathrm{km})$

square kilometer $\left(\mathrm{km}^{2}\right)$

meter per kilometer $(\mathrm{m} / \mathrm{km})$

liter (L)

liter per second (L/s) cubiç meter per second

$$
(\mathrm{m} / \mathrm{s})
$$

meter per day $(\mathrm{m} / \mathrm{d})$

square meter per day $\left(\mathrm{m}^{2} / \mathrm{d}\right)$

microsiemen per centimeter

at $25^{\circ}$ Celsius

(uS/cm at $25^{\circ} \mathrm{C}$ )

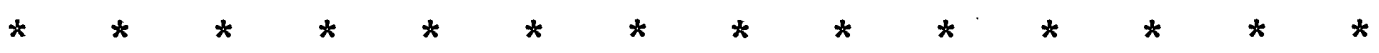

Some aquifer-test data cited in this report are in units no longer used by the U.S. Geological Survey. Conversion factors for these, to accepted units, are cited below:

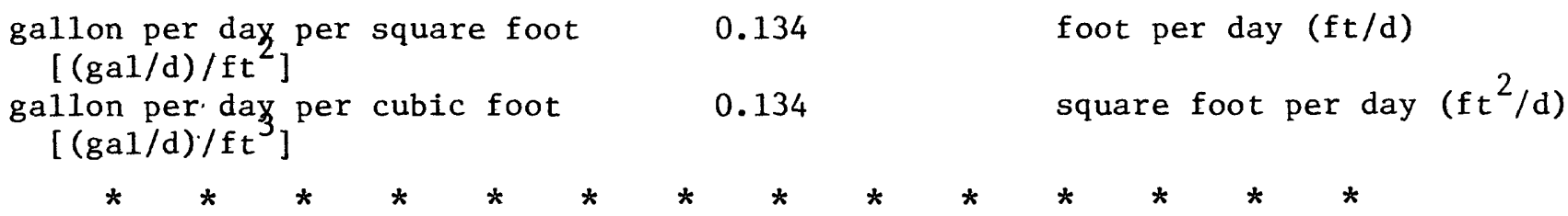

National Geodetic Vertical Datum of 1929 (NGVD of 1929): A geodetic datum derived from a general adjustment of the first-order level nets of both the United States and Canada, formerly called mean sea level. NGVD of 1929 is referred to as sea level in the text of this report. 


\title{
OCCURRENCE AND USE OF GROUND WATER IN THE VENICE-ENGLEWOOD AREA, SARASOTA AND CHARLOTTE COUNTIES, FLORIDA
}

By H. Sutcliffe, Jr. and T. H. Thompson

\begin{abstract}
In an area of about 75 square miles in the coastal parts of southern Sarasota and northern Charlotte Counties, the demand for water by consumers is increasing rapidly because of population growth. Ground water, the chief source of supply, is distributed to users largely by the public water systems of the city of Venice and the Englewood Water District.
\end{abstract}

The principal water-bearing formations in the area include the surficial aquifer; zone 1 in the Tamiami Formation, zone 2 in the upper part of the Hawthorn Formation, and zone 3 in the lower part of the Hawthorn Formation and upper part of the Tampa Limestone that comprise the intermediate aquifers; and zones 4 and 5 in the deeper formations that comprise the Floridan aquifer.

The surficial aquifer, except near tidewater, provides limited supplies of freshwater to wells. Zone 1 is the major aquifer for public water supply in the area. Available information indicates that most of the area between Venice and Englewood, east of State Highway 775 and U.S. Highway 41, contains potable water from zone 1. However, at many places it is contaminated by saline water, either as a result of downward leakage in areas where the surficial aquifer has been inundated by storm-driven tides or by upward leakage of mineralized water from underlying aquifers through uncased or improperly constructed wells.

Although the city of Venice obtains some of its water supply from zone 2, the water is slightly saline in much of the area. In some parts of the area, water from zone 2 is suitable for irrigation. The water level in zone 2 is above land surface and is considerably higher than the water level in zone 1. Consequently, upward leakage of saline water occurs in wells open to both zones, which causes degradation of water quality in zone 1 .

Zone 3 represents the lowermost part of the intermediate aquifers and confining beds in southwest Florida. Zones 4 and 5 constitute the Floridan aquifer in the Venice-Englewood area. In September 1976, the composite water level in these zones was several feet above land surface. Except locally where the water is used for watering livestock and maintaining ponds, the water from zones 3, 4, and 5 is little used because of its poor quality.

The 10 water-supply systems in the Venice-Englewood area have a capacity of about 11 million gallons per day. In 1975, maximum average daily pumpage was about 3 and 1.4 million gallons per day for the city of Venice and the Englewood Water District, respectively; the only major public systems in the area. 


\section{INTRODUCTION}

The Venice-Englewood area includes $20 \mathrm{mi}^{2}$ in Charlotte County and $55 \mathrm{mi}^{2}$ in Sarasota County. The cities of Venice and Englewood are in southwest peninsular Florida. The study area is bounded by the Gulf of Mexico on the west, Coral Creek on the south, the Myakka River on the east, and the city of Venice on the north (fig. 1).

The area is undergoing rapid population growth, taxing the ability of the local utilities to meet the increased demand for water. The population of the city of Venice almost doubled between April 1970 and July 1976 from 6,648 to 12,133 (Thompson, 1977).

All water used in 1976 in the Venice-Englewood area came from wells. There are 10 public-supply systems, locations of which are shown in figure 1 . Outside the public-service areas, water for domestic and other uses is obtained from individual wells.

In 1966, the Englewood Water District put a new system into use that was capable of distributing $1.5 \mathrm{Mgal} / \mathrm{d}$. By 1970, the capacity of the plant and wells was doubled. The Englewood Water District and the city of Venice, the two major public utilities in the area, need additional water supplies that can meet the increased consumer demand and also satisfy the quality standards of the Florida Department of Environmental Regulation (DER). To meet these increased demands, local municipal authorities need detailed information on the location and quality of additional water-supply sources.

Two major problems related to ground-water resources in the Venice-Englewood area are:

1. Lack of information on areal changes in water quality and quantity of available ground water.

2. Contamination of the ground-water resources, including infiltration from leach fields, upward leakage of saline water from deeper zones, and downward percolation of seawater from storm-driven tides.

\section{Purpose and Scope}

The purpose of this report is: (1) to describe the aquifers in the VeniceEnglewood area; (2) to evaluate the quality of ground water in these aquifers; and (3) to document the quantities of ground water used for public supply in the Venice-Englewood area. The investigation included an inventory of wells in the area. The aquifers were delineated and maps were prepared showing selected waterquality parameters for each aquifer. Forty-two test wells were drilled in areas where information was not available. Water samples were collected from each well inventoried and were analyzed for specific conductance, chloride, and sulfate. Selected test wells were pumped, and drawdown and recovery data were obtained. The study was conducted primarily between July 1970 and October 1977. 


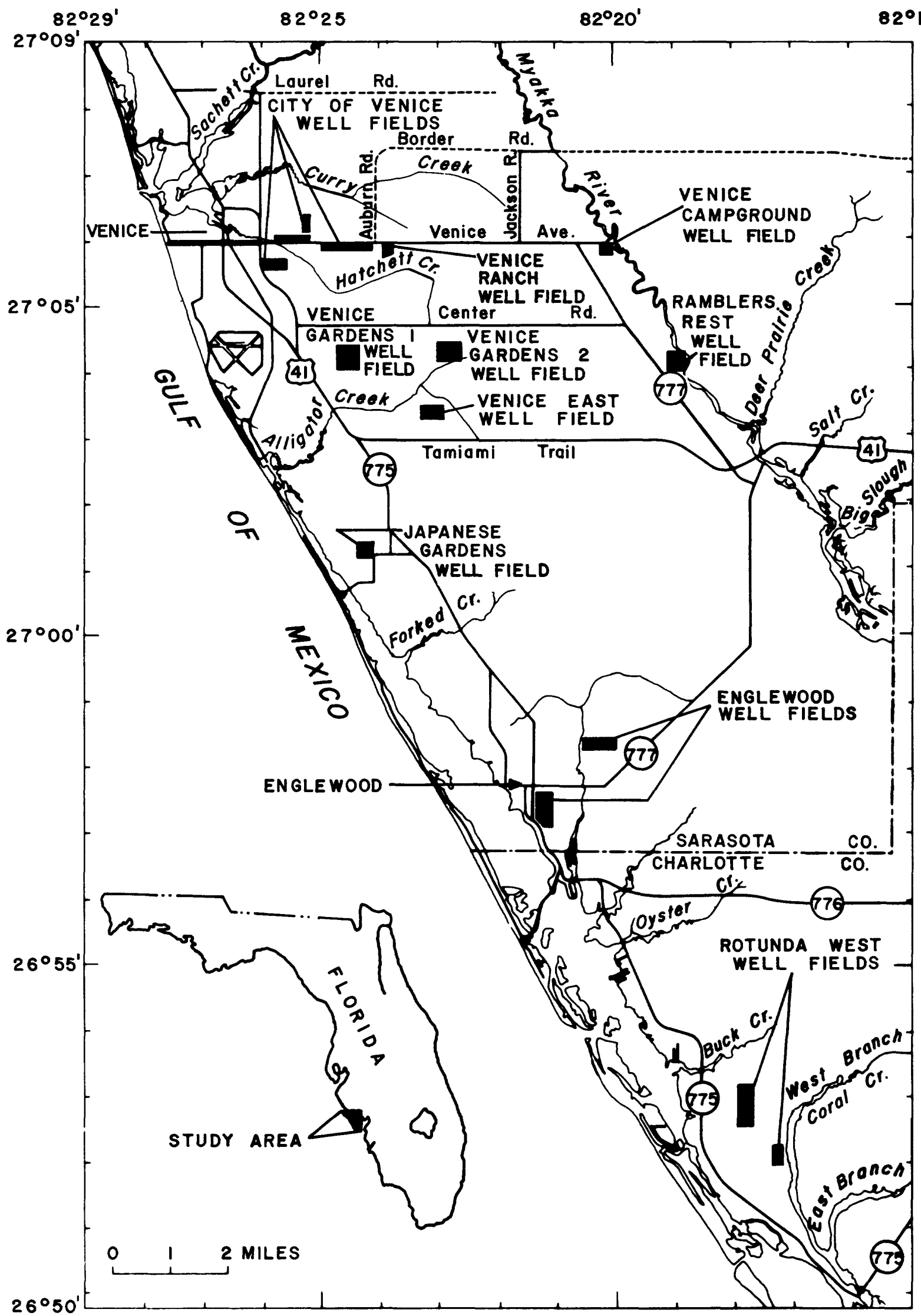

Figure 1.--Locations of the Venice-Englewood area and public water-supply systems. 


\section{Previous Investigations}

Several reports describe specific hydrologic problems within the VeniceEnglewood area, principally near Venice. As early as 1933, Stringfield cited the water problems in the Venice area and in the farming area to the east where, even then, quality-of-water problems were known. Clark (1964) studied the possible effects of a proposed saltwater canal passing close to a well field in the city of Venice. Flippo and Joyner (1968) evaluated water-supply potential of the Myakka River. Their evaluation also included a description of the low-flow characteristics of the Myakka River. In 1975, Sutcliffe reported on the water resources of Charlotte County. In an areal study of the Myakka River basin, Joyner and Sutcliffe (1976) evaluated the hydrology of the Myakka River basin and coastal basins, including a small part of the Venice-Englewood area.

\section{Acknowledgments}

The study was done in cooperation with the Englewood Water District and the Bureau of Geology, Florida Department of Natural Resources. Several other governmental agencies interested in water-resources investigations in this area also contributed valuable information and assistance to the study. Principal among them are the West Coast Inland Navigation District and the city of Venice. Special appreciation is expressed for the assistance of William Lang (deceased) who provided geologic interpretations of the well logs; to Jim Lindsey and Paul Youngberg of the city of Venice; to the members of the city of Venice Water Board; to Wayne Roddy, Superintendent, and the members of the Board of the Englewood Water District for their encouragement and support; and to the numerous other utility managers who provided information on their systems.

Thanks are due Michael Barker, John Maynard, and George Vattamattam who located and sampled the wells east of Venice under the direction of Richard Wolcott of the Sarasota County Health Department.

\section{Description of Area}

The Venice-Englewood area is low-lying with land altitude less than 20 feet above sea level. During the period of early development, many of the sloughs in the area were connected by canals and drained either to the Gulf of Mexico or to the Myakka River so that the rich muck lands and adjacent areas could be farmed. Most of the streams are less than 5 miles long, have relatively low gradients of about $5 \mathrm{ft} / \mathrm{mi}$, and drain to the Gulf of Mexico or the bays lying inside the barrier islands.

The rainfall from 1974 through 1978 in Englewood averaged 44.91 inches per year. About 60 percent of the rainfall occurs from June through September as a result of heavy rains generally associated with convective thunderstorms. Normal rainfall during these months ranges from 5 to 8 inches per month. Annual evapotranspiration was estimated to be 35 to 40 inches in the Myakka River basin northwest of the study area (Joyner and Sutcliffe, 1976). 


\section{HYDROGEOLOGIC SETTING}

In the Venice-Englewood area, only the upper 200 feet of deposits have significant potential as a source of potable ground water for domestic or public supply. Below this depth, the water is too mineralized in its natural state to meet the requirements for drinking water; some of the water, however, is suitable for irrigation and other uses.

The uppermost water-yielding aquifer in the Venice-Englewood area is the surficial aquifer in which water occurs under water-table conditions. Below this aquifer is a series of artesian aquifers consisting of alternating permeable and less permeable deposits that extend to more than 1,000 feet below land surface. The permeable deposits within this sequence are called "zones" in this report. The zones are numbered serially, downward from zone 1 in the Tamiami Formation to zone 5 in the Avon Park Limestone (table 1). The zones have limited stratigraphic significance, as shown in table 1 . Figure 2 is a diagram showing the shallower part of the lithologic column (surficial aquifer and zones 1 and 2).

The principal water-producing zones tapped by wells in the area are the surficial aquifer and artesian zones 1 and 2 . Table 2 summarizes selected hydrologic data including water-quality characteristics of these three zones in two test holes drilled in the Venice-Englewood area. Venice test well 1 is in the city of Venice well field about 1 mile southeast of Venice. Englewood Water District test well R01 is about 2 miles southeast of Englewood.

\section{Surficial Aquifer}

The surficial aquifer (fig. 2, table 1) consists of interbedded layers of fine-to-medium sand, sandy clay, and shell or shell-marl beds. The most permeable parts of the aquifer are the sand layers and the well-sorted shell beds. The aquifer extends from land surface to depths of 5 to 60 feet throughout the study area and is underlain by a sandy clay, marl, or limestone that retards downward percolation of water.

The water table varies from near land surface to as much as 15 feet below land surface in most of the area. In areas of heavy withdrawal, the water table may be at greater depths, and in areas of poor drainage, the water table may be close to the land surface. The aquifer is recharged directly by rainfall and is discharged by withdrawals from wells, by evapotranspiration, and by drainage to streams. The aquifer yields as much as $85 \mathrm{gal} / \mathrm{min}$ from properly constructed and screened wells in the more permeable parts of the aquifer consisting of wellsorted sand and shell beds. Wells in less permeable parts of the aquifer yield from 5 to as much as $25 \mathrm{gal} / \mathrm{min}$.

The surficial aquifer supplies water to 12 of the 20 original supply wells drilled by the Englewood Water District. The capacities of these wells when first tested ranged from 38 to $85 \mathrm{gal} / \mathrm{min}$, and the aggregate yield at design capacity was $425 \mathrm{gal} / \mathrm{min}$. The surficial aquifer is not used by the city of Venice as a source of public water supply because of poor yields to wells in the Venice area. Yields of several test wells drilled at various times by the city were a11 less than $25 \mathrm{gal} / \mathrm{min}$. 
Table 1.--Water-yielding zones in the Venice-Englewood area

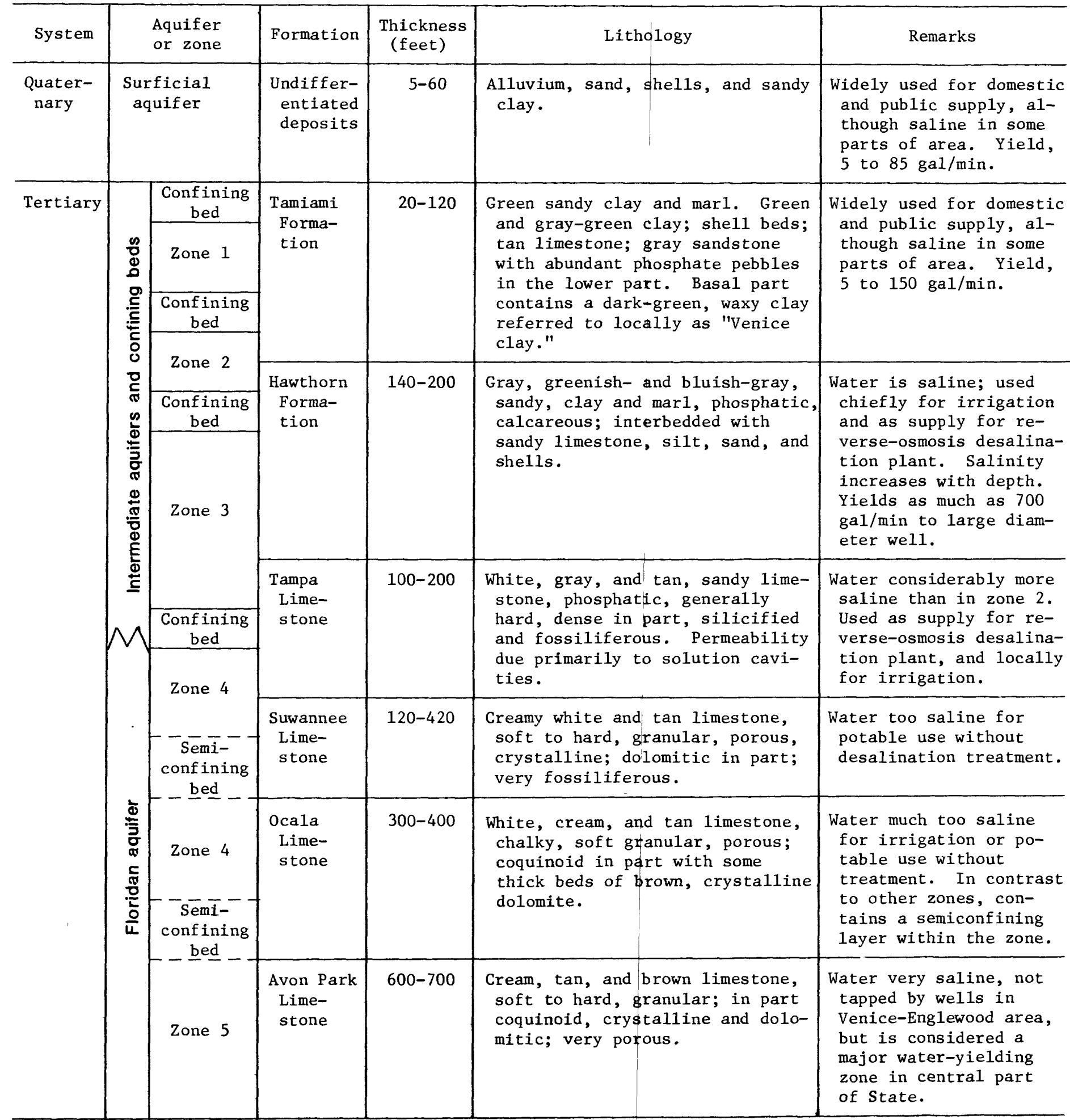




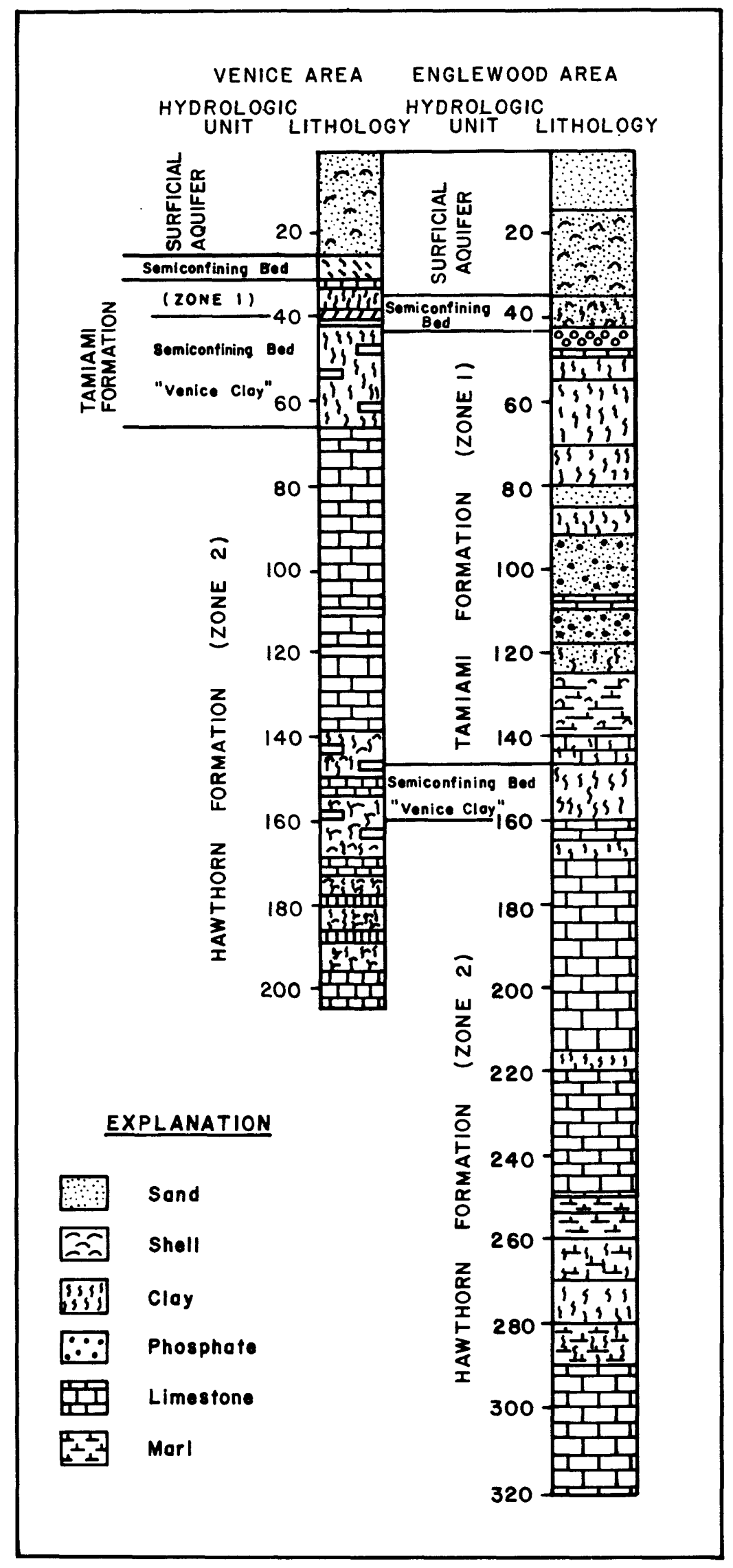

Figure 2.--Generalized lithologic columns of the surficial aquifer and zones 1 and 2 . 


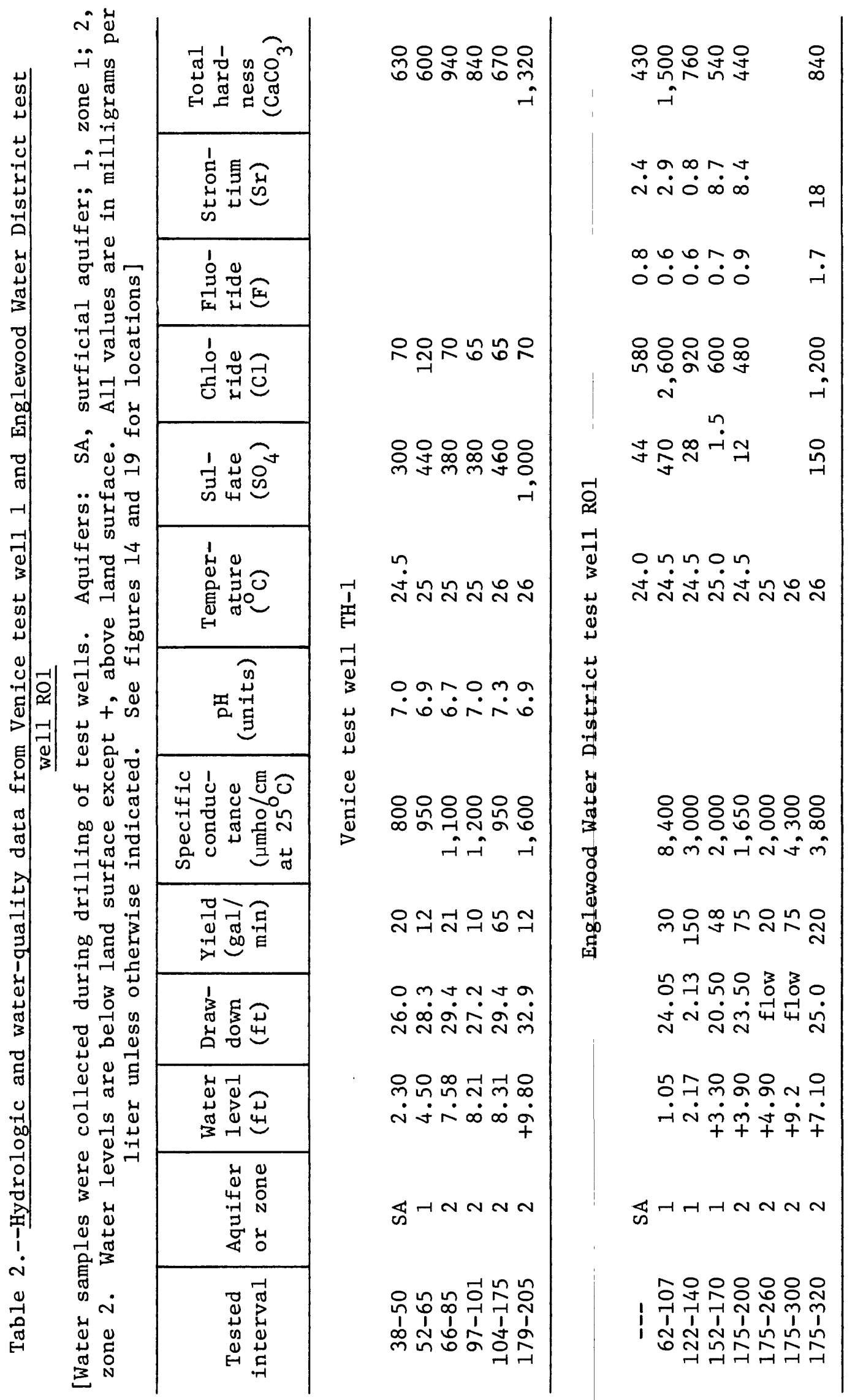


$\underline{\text { Zone } 1}$

Zone 1 is composed of limestone, clays, sands, and shell beds of the Tamiami Formation, constituting the more permeable parts of the formation that are hydraulically connected. These permeable beds occur chiefly in the middle and upper parts of the formation (table 1). The basal part of the Tamiami Formation, referred to locally as "Venice clay," is a dark green or greenish, waxy clay that, in parts of the area, acts as a confining bed between zone 1 and the underlying zone 2 .

Zone 1 ranges in thickness from 20 feet in the northern part of the area to about 120 feet in the southern part. The increase in thickness is predominantly in the sandy and clayey strata and not in the limestone. Although the zone is relatively thin, it yields as much as $150 \mathrm{gal} / \mathrm{min}$ to wells that penetrate the full thickness of the zone.

Water levels in zone 1 are at about the same altitude as the water table in the overlying surficial aquifer in the northern part of the area and slightly higher than the water table in the southern parts. Recharge is from the overlying surficial aquifer when the hydraulic gradient is from the surficial aquifer to zone 1, and particularly where permeable limestone and dolomites of zone 1 are in direct contact with the sandy parts of the surficial aquifer.

Discharge of water from zone 1 is generally by wells with minor losses of water by leakage to adjacent aquifers and discharge into the Gulf of Mexico. Figure 3 shows a daily hydrograph of water level in observation well 6, which taps zone 1 in Englewood, a graph of daily pumpage, and daily rainfall for 1975. Figure 3 shows that when pumpage increases, the water level in the zone declines, and also that pumpage tends to decrease during periods of rainfall.

About half of all wells in the Venice area, including some of the older city wells, produce solely from zone 1. Water used for public supply in Englewood is obtained from wells that tap either zone 1 or the surficial aquifer, but not both.

Clark (1964) reports a transmissivity of $1,100 \mathrm{ft}^{2} / \mathrm{d}$ for the first zone (zone 1) from a pumping test in the Venice area. ${ }_{4} \mathrm{Clark}$ also reported a storage coefficient of $1.3 \times 10^{-4}$ and a leakance of $9.4 \times 10^{-4} \mathrm{ft} / \mathrm{d}$. Tests by the U.S. Geological Survey on eight wells of the Englęwood Water District gave transmissivity values ranging from 3,100 to $8,000 \mathrm{ft}^{2} / \mathrm{d}$, storage coefficjents ranging from $2 \times 10^{-4}$ to $4 \times 10^{-4}$, and a range in leakance values from $4 \times 10^{-4}$ to $5.3 \times 10^{-4}$ $\mathrm{ft} / \mathrm{d}$. Transmissivity is a product of hydraulic conductivity times aquifer thickness. The transmissivity of zone 1 is higher in the Englewood area than in the Venice area, at least in part, because zone 1 near Englewood is thicker.

\section{Zone 2}

Zone 2, in the upper part of the Hawthorn Formation, consists of laminated limestones, clays, sandy clays, and occasional shell beds. This zone is confined above by "Venice clay" and below by a bed of gray to blue-gray clay. The depth to the top of the Hawthorn Formation ranges from less than 40 feet in the north to more than 140 feet in the southern part of the study area (fig. 4). In the 

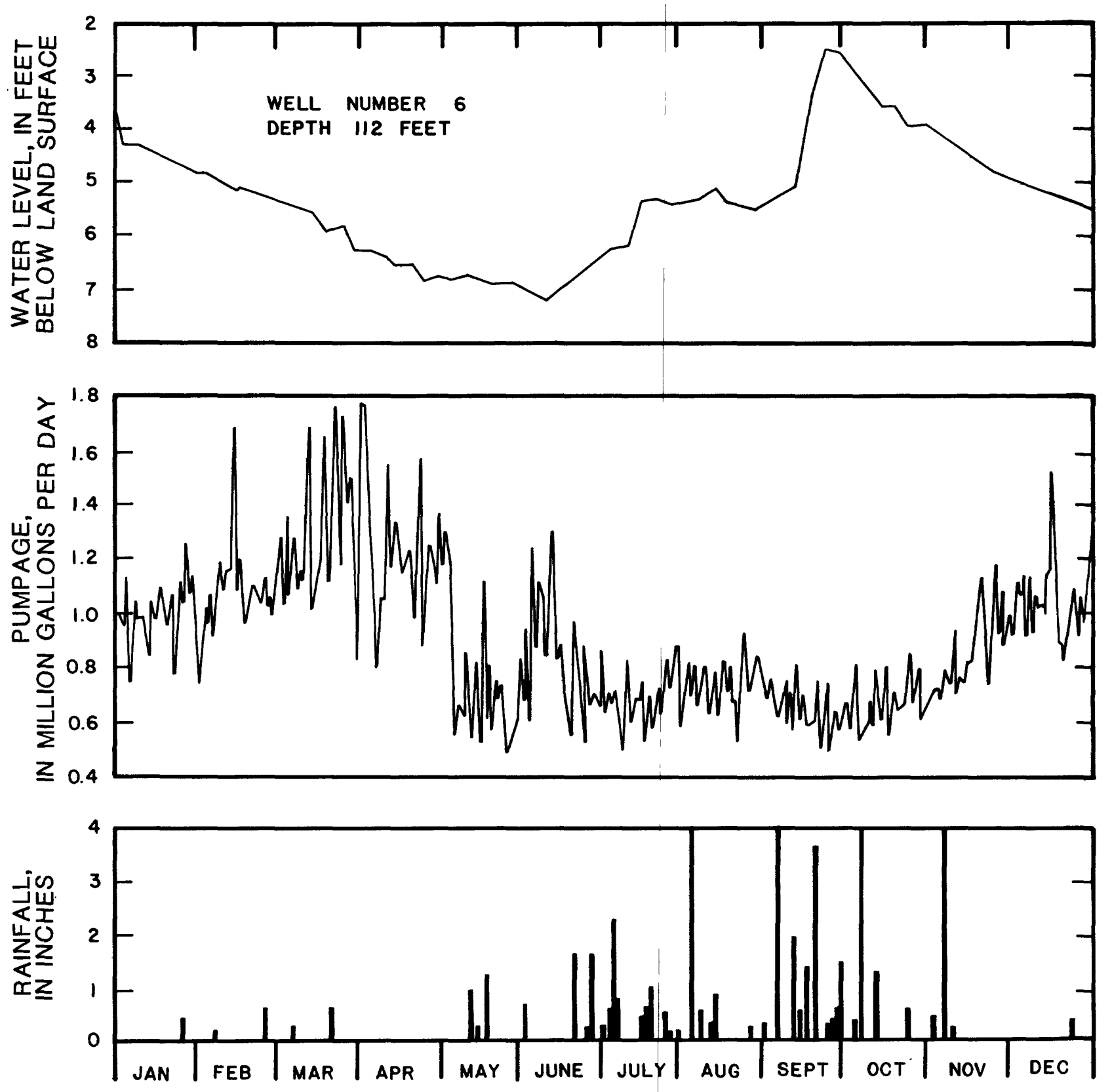

Figure 3.--Rainfall at Englewood, daily pumpage from the Englewood well field, and hydrograph of water level in well 6 in the Englewood well field, 1975. 


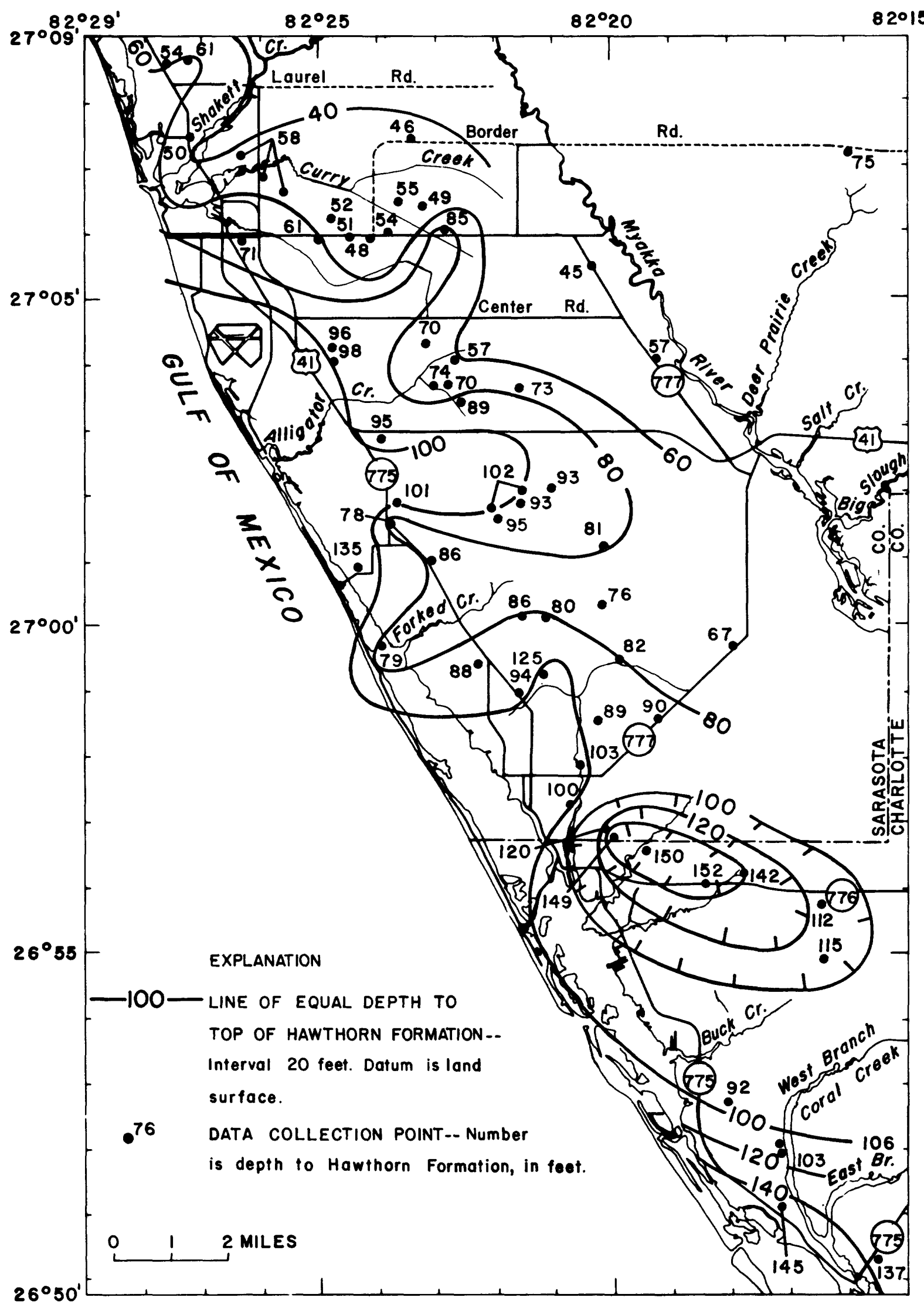

Figure 4.--Depth to top of the Hawthorn Formation. 
Venice-Englewood area, the top of the Hawthorn coincides with the top of zone 2. The surface of the Hawthorn Formation is undulating, but irregular, and generally dips southward or southwestward. Zone 2 ranges in thickness from about 140 feet in the north to more than 200 feet in the south (fig. 2).

Wells open to zone 2 commonly yield 25 to $30 \mathrm{gal} / \mathrm{min}$ but may yield as much as $700 \mathrm{gal} / \mathrm{min}$. Yields from the upper part of this zone in the Venice well field are generally about $120 \mathrm{gal} / \mathrm{min}$. Water levels in zone 2 are higher than in zone 1 and are above land surface over most of the Venice-Englewood area. Recharge to this zone occurs northeast of the area where land-surface altitude is above 40 feet. Discharge from this zone occurs as a result of pumpage from we11s, by submarine discharge to the Gulf of Mexico, and by upward leakage to overlying formations. Two springs that feed Salt Creek in the eastern part of the area and north of U.S. Highway 41 discharge from zone 2 (fig. 4).

The upper 100 feet of zone 2--together with zone 1--furnish most of the water for the city of Venice, other public utilities, and homeowners in the northern part of the area. Much of the irrigation water for farms in the northern part of the area is pumped from zone 2.

\section{Zones 3,4 , and 5}

Zone 3 is in the lower part of the Hawthorn Formation and the upper part of the Tampa Limestone (table 1). The zone consists of sand, sandy limestone, clay, and hard limestone, which is generally gray in color. Zone 3 represents the lowermost part of the intermediate aquifers and confining beds in southwestern Florida. Below zone 3 are persistent limestones that comprise zones 4 and 5; the two zones constitute the Floridan aquifer in the Venice-Englewood area (table 1). Figure 5 shows the potentiometric surface of zones 3, 4, and 5 in a part of southwest Florida for September 1976. At that time, the water level in these zones in the Venice-Englewood area generally ranged from 20 to 30 feet above sea level. Figure 6 shows the potentiometric surface of zones 3, 4, and 5 for May 1977 for the same general region. In the Venice-Englewood area, the potentiometric surface declined seasonally 10 feet or more from the previous autumn levels and was about at land surface. Generally, levels are highest in September at the end of the rainy season and lowest in May following irrigation pumping.

\section{QUALITY OF GROUND WATER}

One factor limiting development of ground-water resources in the VeniceEnglewood area is the quality of water. Excessive chloride and sulfate concentrations and excessive dissolved solids are the major water-quality problems. Fluoride is also a problem in some areas where it occurs in concentrations higher than recommended limits.

Water-quality standards for the State of Florida are determined by the Department of Environmental Regulation (DER). Following are water-quality criteria for drinking water for selected constituents established by the Florida Department of State (1977): 


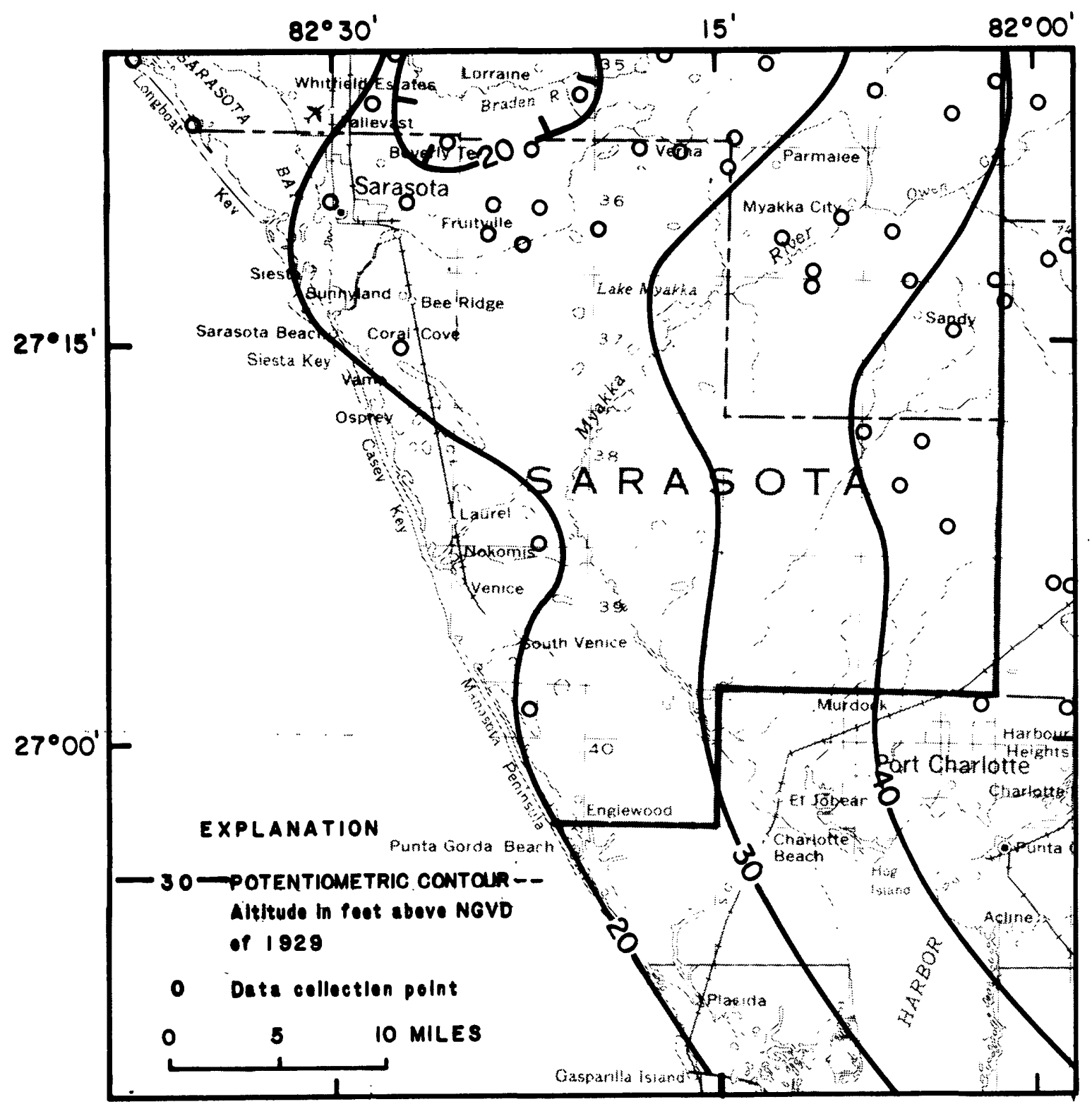

Figure 5.--Potentiometric surface of the Floridan aquifer, September 1976 (from Ryder and others, 1977a). 


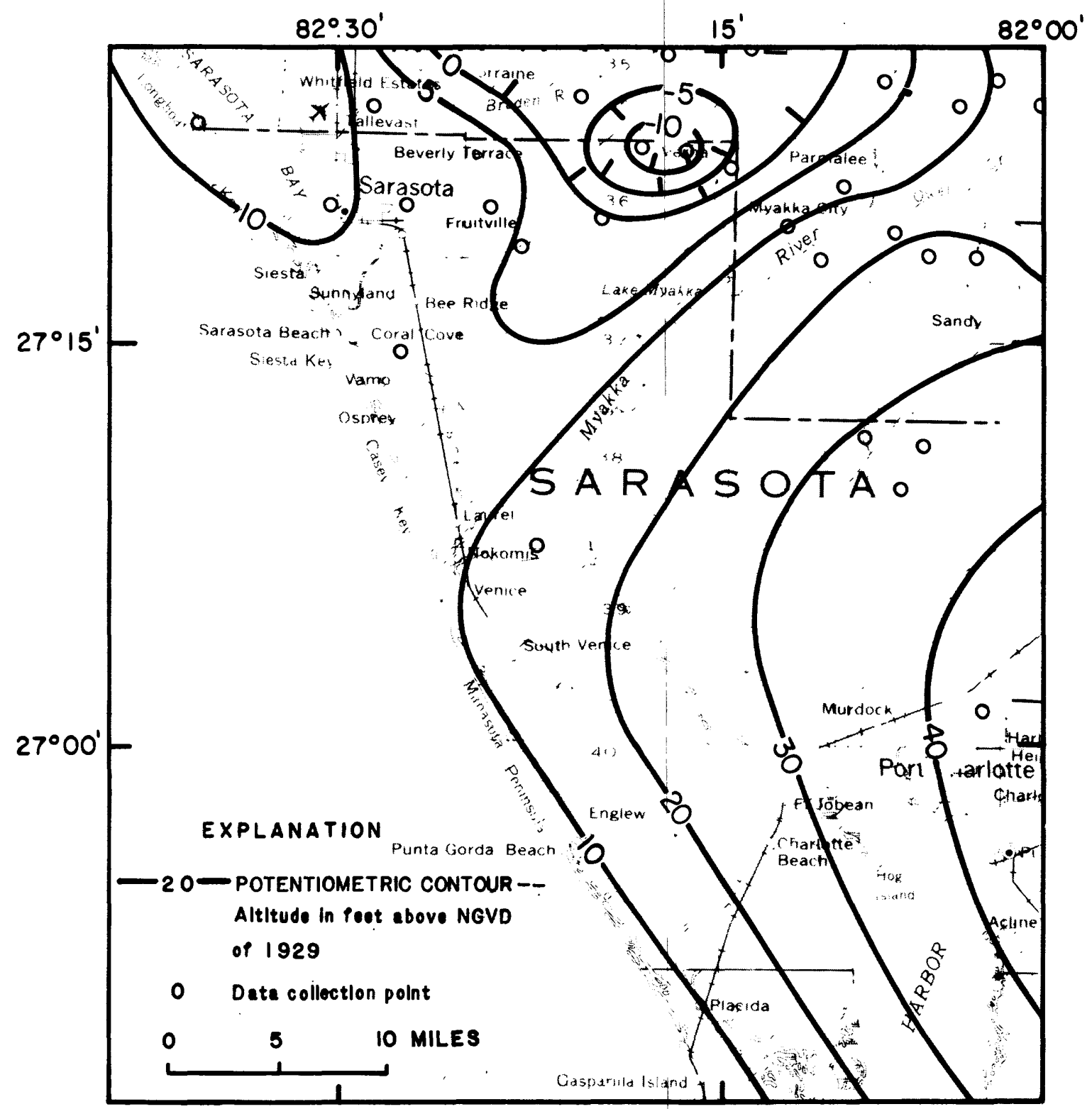

Figure 6.--Potentiometric surface of the Floridan aquifer, May 1977 (from Ryder and others, 1977b). 


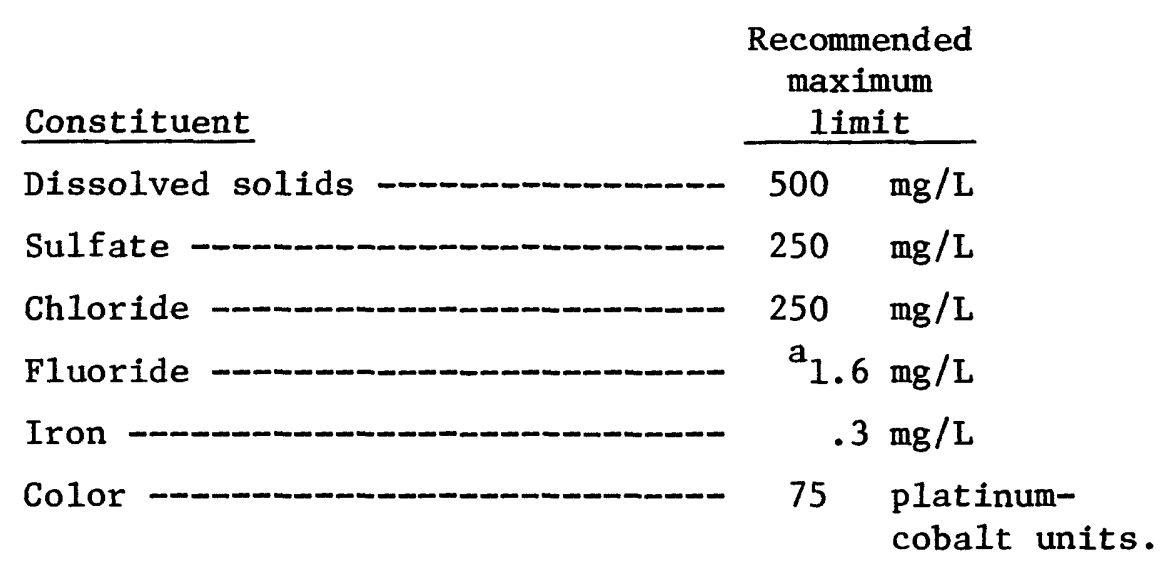

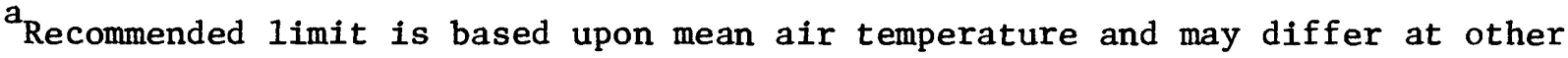
sites in Florida.

\section{Surficial Aquifer}

The surficial aquifer commonly contains potable water, that is, water containing dissolved solids of less than $1,000 \mathrm{mg} / \mathrm{L}$ (milligrams per liter). Table 3 gives analyses of water from a typical production well tapping the surficial aquifer in the Englewood Water District. In some parts of the Venice-Englewood area, particularly south and east of Englewood where the land surface has been inundated by seawater during storms, water in the surficial aquifer contains more than $250 \mathrm{mg} / \mathrm{L}$ of chloride and is considered saline (fig. 7). Water in the surficial aquifer in a very limited area in the southern part of the area is potable; six 3-inch wells produce water from an isolated shell bed just west of the west branch of Coral Creek (fig. 7). Intrusion of seawater has also occurred along the shoreline, and saline water is present in the lower part of the surficial aquifer on the keys just offshore. Saline water also occurs locally in the surficial aquifer where water from deep wells has been allowed to discharge upon the land surface.

Table 4 lists analyses of water from test wells near Englewood and illustrates the range with depth in chemical concentrations in water from the surficial aquifer and from zones 1 and 2. In the surficial aquifer, chlorides range from $35 \mathrm{mg} / \mathrm{L}$ in well. C9 to $740 \mathrm{mg} / \mathrm{L}$ in well 3R. The analysis of water from well 5R at a depth of 45 feet is typical for water in the surficial aquifer beyond the Englewood Water District well field. Table 5 lists hydrologic data and chemical analyses of water from test wells drilled into the surficial aquifer and zones 1 and 2 at the Venice well field. Chloride in water from the surficial aquifer at the well field ranged from 15 to $270 \mathrm{mg} / \mathrm{L}$.

\section{Zone 1}

Zone 1 is the most widely used source of water in the study area for domestic and public water supply. Zone 1 generally contains water of a chemical quality that is acceptable for most uses. However, zone 1 in some areas contains water where chloride concentrations exceed recommended limits for a public supply (fig. 8). Figure 9 shows the areas where the specific conductance of water 


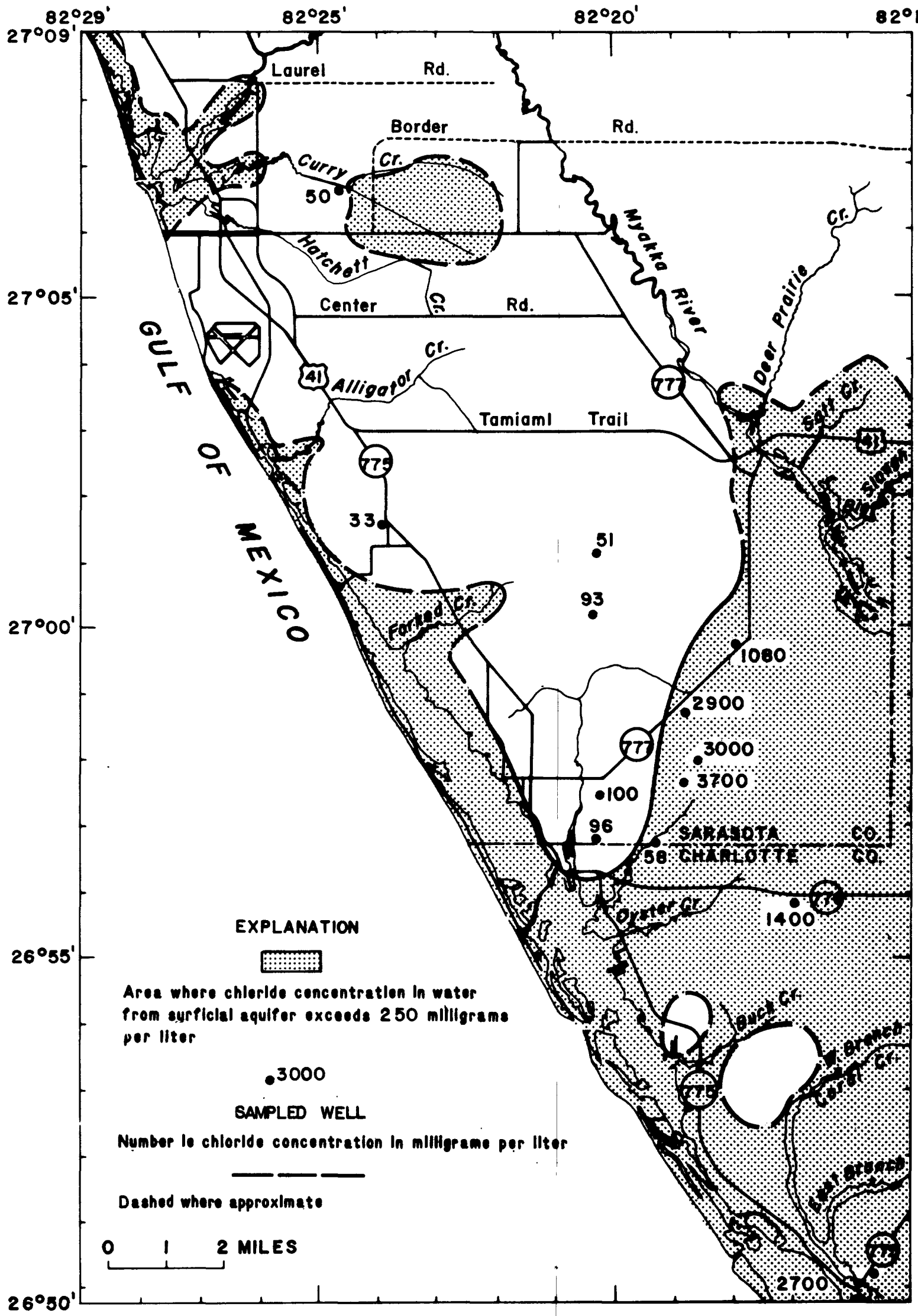

Figure 7.--Areas where chloride concentration in water in the surficial aquifer exceeds 250 milligrams per liter. 
Table 3.--Chemical analyses of water from Englewood Water District we11 20

[Analysis by U.S. Geological Survey. Chemical constituents in milligrams per liter. Location is shown in figure 19; well taps surficial aquifer]

\begin{tabular}{|c|c|c|c|}
\hline \multirow[b]{2}{*}{ Constituent } & \multicolumn{3}{|c|}{ Date of collection } \\
\hline & $\begin{array}{c}\text { June } 28, \\
1972\end{array}$ & $\begin{array}{c}\text { April } \\
1974\end{array}$ & $\begin{array}{c}\text { May } 14, \\
1974\end{array}$ \\
\hline $\begin{array}{l}\text { Calcium, dissolved (Ca) } \\
\text { Magnesium, dissolved (Mg) } \\
\text { Bicarbonate }\left(\mathrm{HCO}_{3}\right) \\
\left.\text { Sulfate, dissolved ( } \mathrm{SO}_{4}\right) \\
\text { Chloride, dissolved (CI) }\end{array}$ & $\begin{array}{l}34 \\
13 \\
14\end{array}$ & & $\begin{array}{l}17 \\
3.1 \\
37 \\
15 \\
22\end{array}$ \\
\hline $\begin{array}{l}\text { Fluoride, dissolved (F) } \\
\text { Nitrate nitrogen }\left(\mathrm{NO}_{3}-\mathrm{N}\right) \\
\text { Nitrite nitrogen }\left(\mathrm{NO}_{2}-\mathrm{N}\right) \\
\text { Ammonia nitrogen, total as } \mathrm{N} \\
\text { Organic nitrogen, total as } \mathrm{N}\end{array}$ & 0.7 & $\begin{array}{l}0.01 \\
0.00 \\
0.55 \\
0.36\end{array}$ & 0.8 \\
\hline $\begin{array}{l}\text { Phosphorus, total as } \mathrm{P} \\
\text { Phosphorus, total ortho as } \mathrm{P} \\
\text { Hardness as } \mathrm{CaCO}_{3} \\
\text { Noncarbonate hardness } \\
\text { Specific conductance } \\
\left.\text { ( } \mu \mathrm{mho} / \mathrm{cm} \text { at } 25^{\circ} \mathrm{C}\right)\end{array}$ & 51 & $\begin{array}{l}1.40 \\
1.30\end{array}$ & $\begin{array}{r}55 \\
25 \\
180\end{array}$ \\
\hline $\begin{array}{l}\mathrm{pH} \text { (units) } \\
\text { Water temperature }\left({ }^{\circ} \mathrm{C}\right) \\
\text { Strontium, dissolved }(\mathrm{Sr})\end{array}$ & 6.0 & & $\begin{array}{c}6.0 \\
23.5 \\
0.100\end{array}$ \\
\hline
\end{tabular}

in zone 1 exceeds $1,000 \mu$ mho/cm (micromhos per centimeter at $25^{\circ} \mathrm{C}$ ); a conductance of this magnitude indicates that the water exceeds the recommended maximum limit for drinking water of $500 \mathrm{mg} / \mathrm{L}$ for dissolved solids concentration (Florida Department of State, 1977). Figure 9 may be used to identify favorable areas for the development of water supplies from zone 1.

An inventory of wells was made in an $8-\mathrm{mi}^{2}$ area east of Venice. Water from each well was sampled and analyzed for specific conductance, chloride, sulfate, and total hardness (table 5). Figure 10 is a map showing specific conductance of water from selected wells less than 200 feet deep. Most specific-conductance values greater than $2,000 \mu \mathrm{mho} / \mathrm{cm}$ (indicating relatively high concentrations of dissolved solids) are probably due to the upward migration of saline water from deeper zones with higher artesian pressure (head). Some residual seawater may also remain in the aquifer from a period of higher sea level in the past.

The western part of the Venice-Englewood area between State Highway 775, U.S. Highway 41, and State Highway 777 (fig. 1) was tested by drilling. Nine of 12 wells were open to zone 1 . The water from zone 1 in two we1ls is potable (table 4) and meets the DER water-quality standards (Florida Department of State, 1977). 


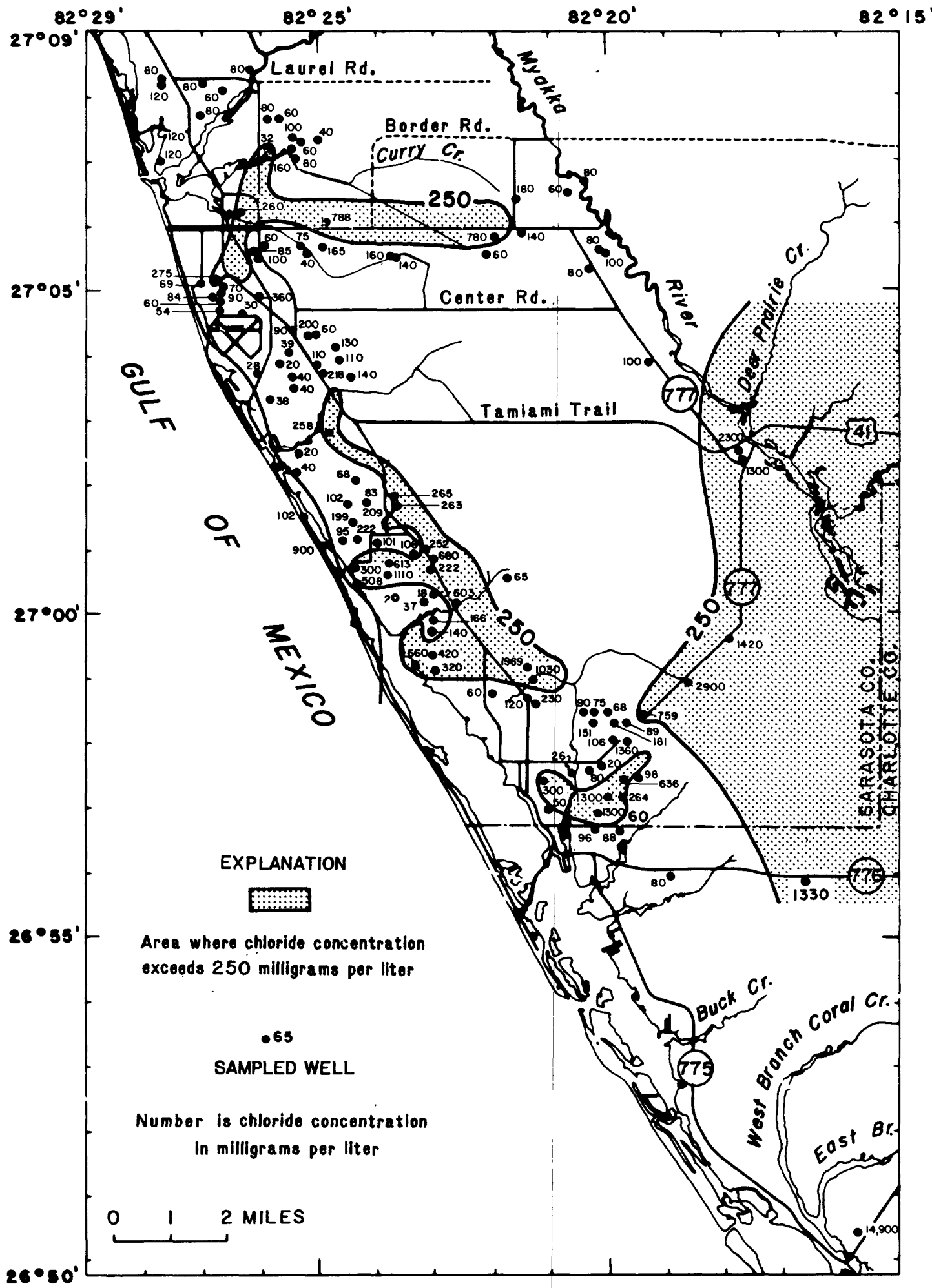

Figure 8.--Areas where chloride concentration in water from zone 1 exceeds 250 milligrams per liter. 


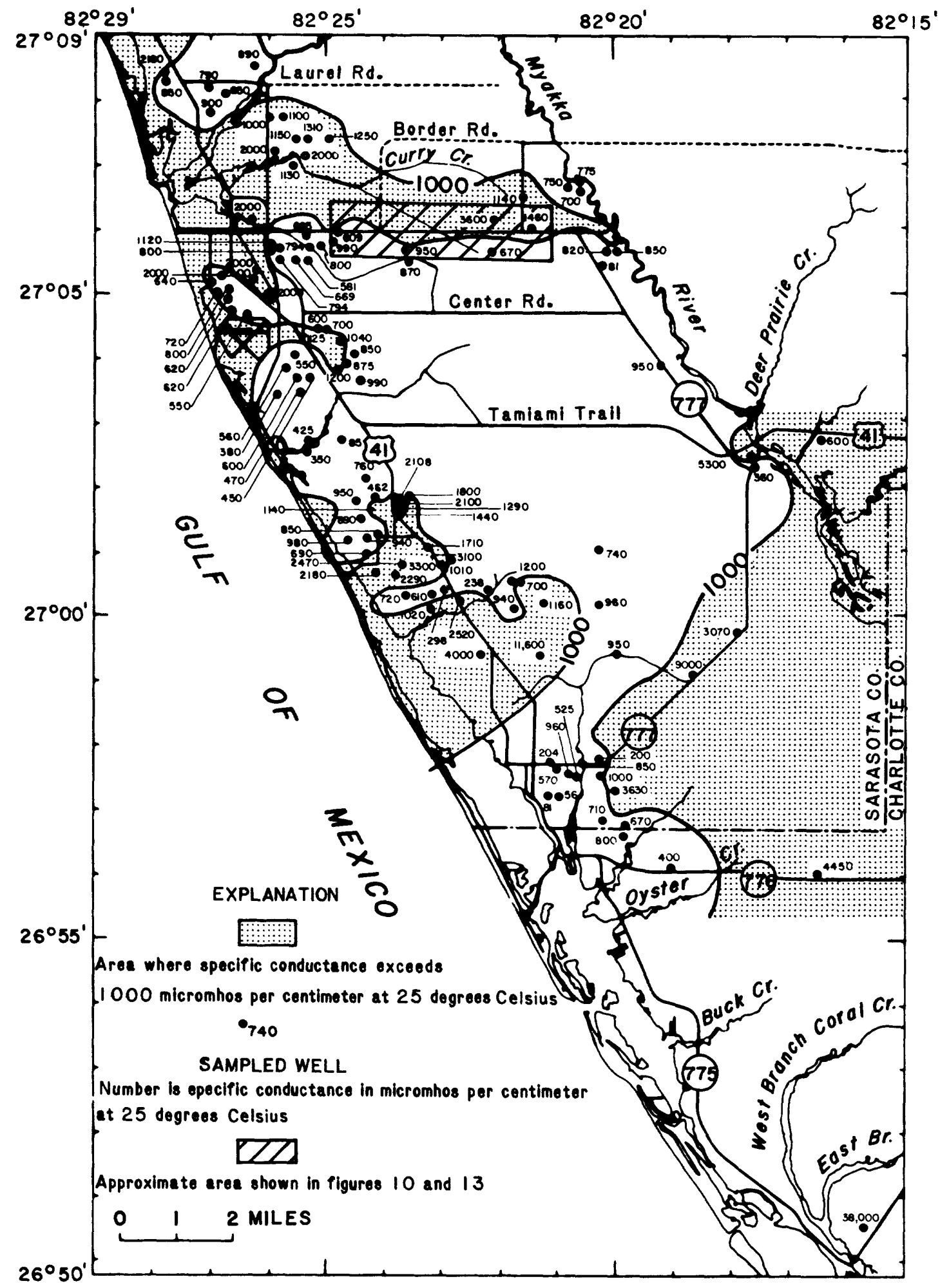

Figure 9.--Areas where specific conductance of water from zone 1 exceeds 1,000 micromhos per centimeter at $25^{\circ}$ Celsius. 


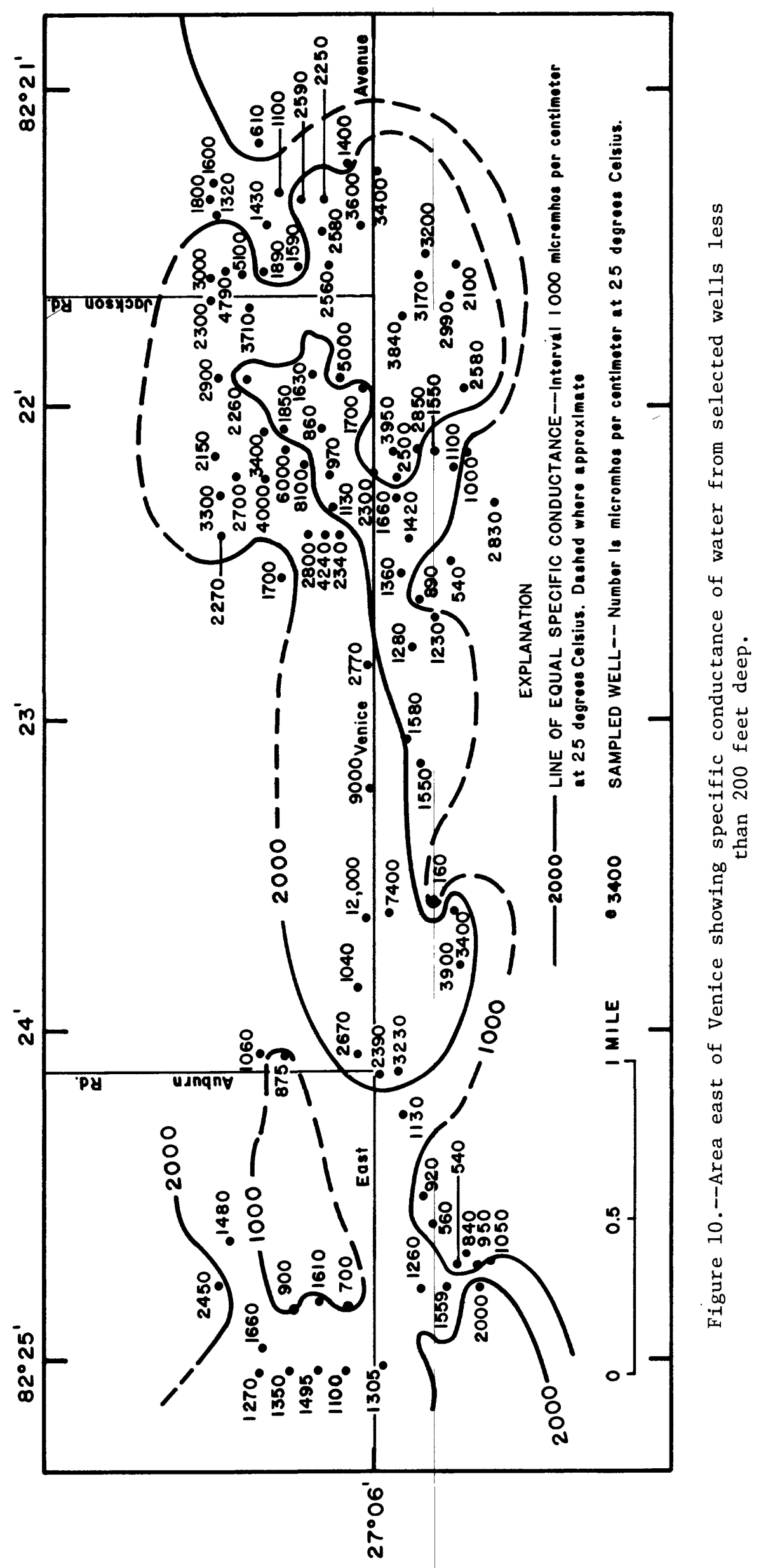


Table 4.--Chemical analyses of water from test wells of the Englewood Water District

[Aquifer or zone: SA, Surficial aquifer; 1, zone 1; 2, zone 2. Analyses by U.S. Geological Survey. See figure 19 for location]

\begin{tabular}{|c|c|c|c|c|c|c|c|c|}
\hline We11 & Date & Time & $\begin{array}{l}\text { Aquifer } \\
\text { or zone }\end{array}$ & $\begin{array}{l}\text { Depth } \\
\text { (ft) }\end{array}$ & $\begin{array}{c}\text { Tempera- } \\
\text { ture } \\
\left({ }^{0} \mathrm{C}\right)\end{array}$ & $\begin{array}{l}\text { Color } \\
\text { (plati- } \\
\text { num- } \\
\text { cobalt } \\
\text { units) }\end{array}$ & $\begin{array}{c}\text { Specific } \\
\text { conduc- } \\
\text { tance } \\
(\mu \mathrm{mho} / \mathrm{cm} \\
\left.\text { at } 25^{\circ} \mathrm{C}\right)\end{array}$ & $\underset{\text { (units) }}{\mathrm{pH}}$ \\
\hline R01 & $\begin{array}{l}12-02-75 \\
12-08-75 \\
12-09-75 \\
12-10-75 \\
12-11-75 \\
12-17-75\end{array}$ & $\begin{array}{l}1530 \\
1200 \\
1430 \\
1110 \\
1000 \\
1555\end{array}$ & $\begin{array}{c}\text { SA } \\
1 \\
1 \\
1 \\
2 \\
2\end{array}$ & $\begin{array}{r}48 \\
107 \\
140 \\
170 \\
200 \\
320\end{array}$ & $\begin{array}{l}24.0 \\
24.5 \\
24.5 \\
25.0 \\
24.5 \\
26.0\end{array}$ & $\begin{array}{l}-- \\
-- \\
-- \\
-- \\
-- \\
0.0\end{array}$ & $\begin{array}{l}-- \\
-- \\
-- \\
-- \\
-- \\
4,050\end{array}$ & $\begin{array}{l}7.4 \\
7.4 \\
7.5 \\
7.5 \\
7.5 \\
7.5\end{array}$ \\
\hline Ro2 & $\begin{array}{l}12-23-75 \\
12-30-75 \\
12-30-75 \\
01-06-76\end{array}$ & $\begin{array}{l}1400 \\
0800 \\
1401 \\
1600\end{array}$ & $\begin{array}{l}1 \\
1 \\
1 \\
2\end{array}$ & $\begin{array}{r}93 \\
120 \\
168 \\
310\end{array}$ & $\begin{array}{l}24.0 \\
24.5 \\
24.5 \\
25.5\end{array}$ & $\begin{array}{l}-- \\
-- \\
-- \\
0.0\end{array}$ & $\begin{array}{r}610 \\
3,800 \\
3,800 \\
4,700\end{array}$ & $\begin{array}{l}7.8 \\
7.7 \\
7.3 \\
7.2\end{array}$ \\
\hline $1 R$ & $05-21-74$ & 1700 & 1 & 90 & -- & 20 & 4,000 & 7.4 \\
\hline $2 \mathrm{R}$ & $05-22-74$ & 1000 & 1 & 110 & -- & 20 & 540 & 8.3 \\
\hline $3 R$ & $\begin{array}{l}05-22-74 \\
05-04-78\end{array}$ & $\begin{array}{l}1800 \\
1100\end{array}$ & $\begin{array}{l}\text { SA } \\
\text { SA }\end{array}$ & $\begin{array}{l}42 \\
42\end{array}$ & $\begin{array}{l}-- \\
--\end{array}$ & -- & $\begin{array}{l}4,000 \\
2,940\end{array}$ & $\begin{array}{l}--- \\
---\end{array}$ \\
\hline $4 \mathrm{R}$ & $\begin{array}{l}06-04-74 \\
06-05-74\end{array}$ & $\begin{array}{l}1200 \\
1000\end{array}$ & $\begin{array}{l}\text { SA } \\
\text { SA }\end{array}$ & $\begin{array}{l}45 \\
55\end{array}$ & $\begin{array}{l}-- \\
--\end{array}$ & $\begin{array}{l}100 \\
100\end{array}$ & $\begin{array}{l}1,160 \\
1,120\end{array}$ & $\begin{array}{l}8.1 \\
8.0\end{array}$ \\
\hline $5 R$ & $06-05-74$ & 1700 & SA & 45 & -- & 3 & 940 & 7.9 \\
\hline $6 R$ & $06-05-74$ & 1000 & 1 & 112 & -- & 3 & 11,600 & 7.4 \\
\hline $\mathrm{C7}$ & $\begin{array}{l}11-18-75 \\
11-20-75\end{array}$ & $\begin{array}{l}1630 \\
1320\end{array}$ & $\begin{array}{c}\mathrm{SA} \\
1\end{array}$ & $\begin{array}{r}35 \\
120\end{array}$ & $\begin{array}{l}24.5 \\
24.0\end{array}$ & $\overline{0 .}$ & $\begin{array}{r}960 \\
1,020\end{array}$ & $\begin{array}{l}7.2 \\
7.6\end{array}$ \\
\hline $\mathrm{C} 8$ & $\begin{array}{l}11-21-75 \\
11-21-75\end{array}$ & $\begin{array}{l}1000 \\
1600\end{array}$ & $\begin{array}{c}\mathrm{SA} \\
1\end{array}$ & $\begin{array}{r}50 \\
110\end{array}$ & $\begin{array}{l}24.5 \\
24.0\end{array}$ & $\overline{0 .}$ & $\begin{array}{r}950 \\
2,200\end{array}$ & $\begin{array}{l}7.4 \\
7.4\end{array}$ \\
\hline $\mathrm{C} 9$ & $\begin{array}{l}11-24-75 \\
11-25-75 \\
11-26-75 \\
11-26-75\end{array}$ & $\begin{array}{l}1630 \\
1600 \\
1100 \\
1600\end{array}$ & $\begin{array}{c}\text { SA } \\
\text { SA } \\
1 \\
1\end{array}$ & $\begin{array}{r}35 \\
55 \\
65 \\
120\end{array}$ & $\begin{array}{l}-- \\
24.0 \\
23.5 \\
24.0\end{array}$ & $\begin{array}{l}-- \\
-- \\
-- \\
0.0\end{array}$ & $\begin{array}{l}700 \\
750 \\
740 \\
720\end{array}$ & $\begin{array}{l}7.5 \\
7.4 \\
7.5 \\
7.5\end{array}$ \\
\hline $\mathrm{C} 10$ & $01-19-76$ & 1400 & 1 & 70 & 23.5 & 10 & 700 & 7.2 \\
\hline
\end{tabular}


Table 4.--Chemical analyses of water from test wells of the Englewood Water District--Continued

\begin{tabular}{|c|c|c|c|c|c|c|c|c|c|}
\hline We11 & $\begin{array}{l}\text { Aquifer } \\
\text { or zone }\end{array}$ & $\begin{array}{l}\text { Alka- } \\
\text { linity } \\
\text { as } \\
\mathrm{CaCO}_{3} \\
(\mathrm{mg} / \mathrm{L})\end{array}$ & $\begin{array}{l}\text { Bicar- } \\
\text { bonate } \\
\left(\mathrm{CO}_{3}\right) \\
(\mathrm{mg} / \mathrm{L})\end{array}$ & $\begin{array}{l}\text { Hard- } \\
\text { ness } \\
(\mathrm{Ca}, \mathrm{Mg}) \\
(\mathrm{mg} / \mathrm{L})\end{array}$ & $\begin{array}{c}\text { Noncar- } \\
\text { bonate } \\
\text { hard- } \\
\text { ness } \\
(\mathrm{mg} / \mathrm{L})\end{array}$ & $\begin{array}{c}\text { Cal- } \\
\text { cium } \\
(\mathrm{Ca}) \\
(\mathrm{mg} / \mathrm{L})\end{array}$ & $\begin{array}{l}\text { Magne- } \\
\text { sium } \\
(\mathrm{Mg}) \\
(\mathrm{mg} / \mathrm{L})\end{array}$ & $\begin{array}{l}\text { Sodium } \\
(\mathrm{Na}) \\
(\mathrm{mg} / \mathrm{L})\end{array}$ & $\begin{array}{l}\text { Potas- } \\
\text { sium } \\
(\mathrm{K}) \\
(\mathrm{mg} / \mathrm{L})\end{array}$ \\
\hline \multirow[t]{6}{*}{ R01 } & SA & 179 & 218 & 430 & 250 & 130 & 25 & -- & -- \\
\hline & 1 & 145 & 177 & 1,510 & 1,370 & 280 & 190 & -- & -- \\
\hline & 1 & 125 & 152 & 760 & 630 & 180 & 76 & -- & -- \\
\hline & 1 & 122 & 149 & 540 & 420 & 120 & 57 & --- & -- \\
\hline & 2 & 126 & 154 & 440 & 310 & 96 & 47 & --- & -- \\
\hline & 2 & 131 & 159 & 840 & 710 & 136 & 120 & 490 & 17 \\
\hline \multirow[t]{4}{*}{ R02 } & 1 & 246 & 300 & 260 & 14 & 93 & 6.6 & --- & -- \\
\hline & 1 & 241 & 294 & 320 & 79 & 110 & 11 & --- & -- \\
\hline & 1 & 159 & 169 & 920 & 780 & 200 & 98 & --- & -- \\
\hline & 2 & 134 & 164 & 1,000 & 870 & 210 & 110 & 540 & 19 \\
\hline $1 R$ & 1 & 182 & 222 & 890 & 710 & 310 & 28 & 660 & 6.0 \\
\hline $2 \mathrm{R}$ & 1 & 200 & 244 & 260 & 62 & 95 & 5.8 & 19 & 1.1 \\
\hline \multirow[t]{2}{*}{$3 R$} & $\mathrm{SA}$ & --- & --- & -- & --- & -- & --- & -- & -- \\
\hline & $\mathrm{SA}$ & 200 & 240 & 750 & 550 & 190 & 63 & 330 & 6.0 \\
\hline \multirow[t]{2}{*}{$4 R$} & SA & 362 & 441 & 430 & 63 & 140 & 18 & 100 & 1.5 \\
\hline & $\mathrm{SA}$ & 367 & 447 & 430 & 58 & 140 & 18 & 100 & 1.5 \\
\hline $5 R$ & $\mathrm{SA}$ & 278 & 339 & 330 & 47 & 110 & 12 & 76 & 1.3 \\
\hline $6 \mathrm{R}$ & 1 & 137 & 167 & 2,200 & 2,100 & 440 & 250 & 2,100 & 40 \\
\hline \multirow[t]{2}{*}{ C7 } & $\mathrm{SA}$ & 386 & 471 & 410 & 24 & 150 & 9.3 & -- & -- \\
\hline & 1 & 147 & 180 & 300 & 150 & 73 & 28 & 78 & 5.7 \\
\hline \multirow[t]{2}{*}{$\mathrm{C} 8$} & $\mathrm{SA}$ & 414 & 504 & 430 & 16 & 150 & 14 & --- & -- \\
\hline & 1 & 151 & 184 & 580 & 430 & 130 & 61 & 190 & 6.8 \\
\hline \multirow[t]{4}{*}{ C9 } & $\mathrm{SA}$ & 320 & 391 & 360 & 39 & 140 & 3.2 & -- & -- \\
\hline & SA & 372 & 453 & 380 & 8 & 140 & 7.8 & -- & -- \\
\hline & 1 & 193 & 235 & 290 & 97 & 32 & 20 & -- & -- \\
\hline & 1 & 186 & 227 & 310 & 120 & 82 & 26 & 58 & 4.3 \\
\hline C10 & 1 & 297 & 362 & 300 & 3 & 110 & 7.1 & 36 & 0.7 \\
\hline
\end{tabular}


Table 4.--Chemical analyses of water from test wells of the Englewood Water District--Continued

\begin{tabular}{|c|c|c|c|c|c|c|c|c|}
\hline We11 & $\begin{array}{l}\text { Aquifer } \\
\text { or zone }\end{array}$ & $\begin{array}{l}\text { Chlo- } \\
\text { ride } \\
(\mathrm{Cl}) \\
(\mathrm{mg} / \mathrm{L})\end{array}$ & $\begin{array}{l}\text { Sul- } \\
\text { fate } \\
\left(\mathrm{SO}_{4}\right) \\
(\mathrm{mg} / \mathrm{L})\end{array}$ & $\begin{array}{l}\text { Fluo- } \\
\text { ride } \\
(\mathrm{F}) \\
(\mathrm{mg} / \mathrm{L})\end{array}$ & $\begin{array}{l}\text { Silica } \\
\left(\mathrm{SiO}_{2}\right) \\
(\mathrm{mg} / \mathrm{t})\end{array}$ & $\begin{array}{l}\text { Stron- } \\
\text { tium } \\
(\mathrm{Sr}) \\
(\mu \mathrm{g} / \mathrm{L})\end{array}$ & $\begin{array}{l}\text { Dis- } \\
\text { solved } \\
\text { solids } \\
\text { (resi- } \\
\text { due at } \\
180^{\circ} \mathrm{C} \text { ) } \\
(\mathrm{mg} / \mathrm{L})\end{array}$ & $\begin{array}{l}\text { Dis- } \\
\text { solved } \\
\text { solids } \\
\text { (sum of } \\
\text { consti- } \\
\text { tuents) } \\
\text { (mg/L) }\end{array}$ \\
\hline \multirow[t]{6}{*}{ R01 } & SA & 580 & 44 & 0.8 & -- & 2,400 & -- & -- \\
\hline & 1 & 2,600 & 470 & 0.6 & -- & 29,000 & - & - \\
\hline & 1 & 920 & 28 & 0.6 & -- & 800 & -- & - \\
\hline & 1 & 600 & 1.5 & 0.7 & -- & 8,700 & - & - \\
\hline & 2 & 480 & 12 & 0.9 & -- & 8,400 & -- & - \\
\hline & 2 & 1,200 & 150 & 1.7 & 19 & 18,000 & 2,320 & 2,200 \\
\hline \multirow[t]{4}{*}{$\mathrm{RO} 2$} & 1 & 46 & 0.3 & 0.2 & -- & 850 & -- & -- \\
\hline & 1 & 120 & 1.6 & 0.2 & -- & 1,300 & -- & -- \\
\hline & 1 & 1,200 & 170 & 0.5 & -- & 16,000 & -- & -- \\
\hline & 2 & 1,400 & 160 & 1.1 & 16 & 30,000 & 2,866 & 2,600 \\
\hline $1 \mathrm{R}$ & 1 & 1,600 & 36 & 0.3 & 19 & 2,500 & 2,340 & 2,770 \\
\hline $2 \mathrm{R}$ & 1 & 40 & 29 & 0.2 & 17 & 1,100 & 390 & 329 \\
\hline \multirow[t]{2}{*}{$3 R$} & $\mathrm{SA}$ & -- & -- & -- & -- & -- & -- & -- \\
\hline & SA & 740 & 220 & 0.4 & 16 & 1,200 & 2,040 & 1,700 \\
\hline \multirow[t]{2}{*}{$4 \mathrm{R}$} & SA & 150 & 34 & 0.4 & 17 & 1,200 & 636 & 680 \\
\hline & SA & 160 & 21 & 0.5 & 17 & 1,200 & 740 & 680 \\
\hline $5 R$ & SA & 130 & 13 & 0.1 & 14 & 700 & 499 & 524 \\
\hline $6 \mathrm{R}$ & 1 & 3,900 & 650 & 0.8 & 16 & 52,000 & 873 & 7,530 \\
\hline \multirow[t]{2}{*}{ C7 } & SA & 93 & 15 & 0.4 & -- & 980 & -- & -- \\
\hline & 1 & 230 & 12 & 1.1 & 33 & 2,700 & 644 & 550 \\
\hline \multirow[t]{2}{*}{$\mathrm{C} 8$} & SA & 83 & 0.9 & 0.3 & -- & 990 & -- & -- \\
\hline & 1 & 620 & 15 & 0.6 & 22 & 7,400 & 1,290 & 1,100 \\
\hline \multirow[t]{4}{*}{$\mathrm{C9}$} & SA & 51 & 0.4 & 0.3 & -- & 880 & - & - \\
\hline & SA & 35 & 0.3 & 0.3 & -- & 820 & -- & -- \\
\hline & 1 & 110 & 30 & 0.5 & -- & 1,700 & -- & -- \\
\hline & 1 & 190 & 11 & 0.7 & 22 & 2,600 & 536 & 510 \\
\hline C10 & 1 & 60 & 0.4 & 0.1 & 12 & 500 & 423 & 400 \\
\hline
\end{tabular}




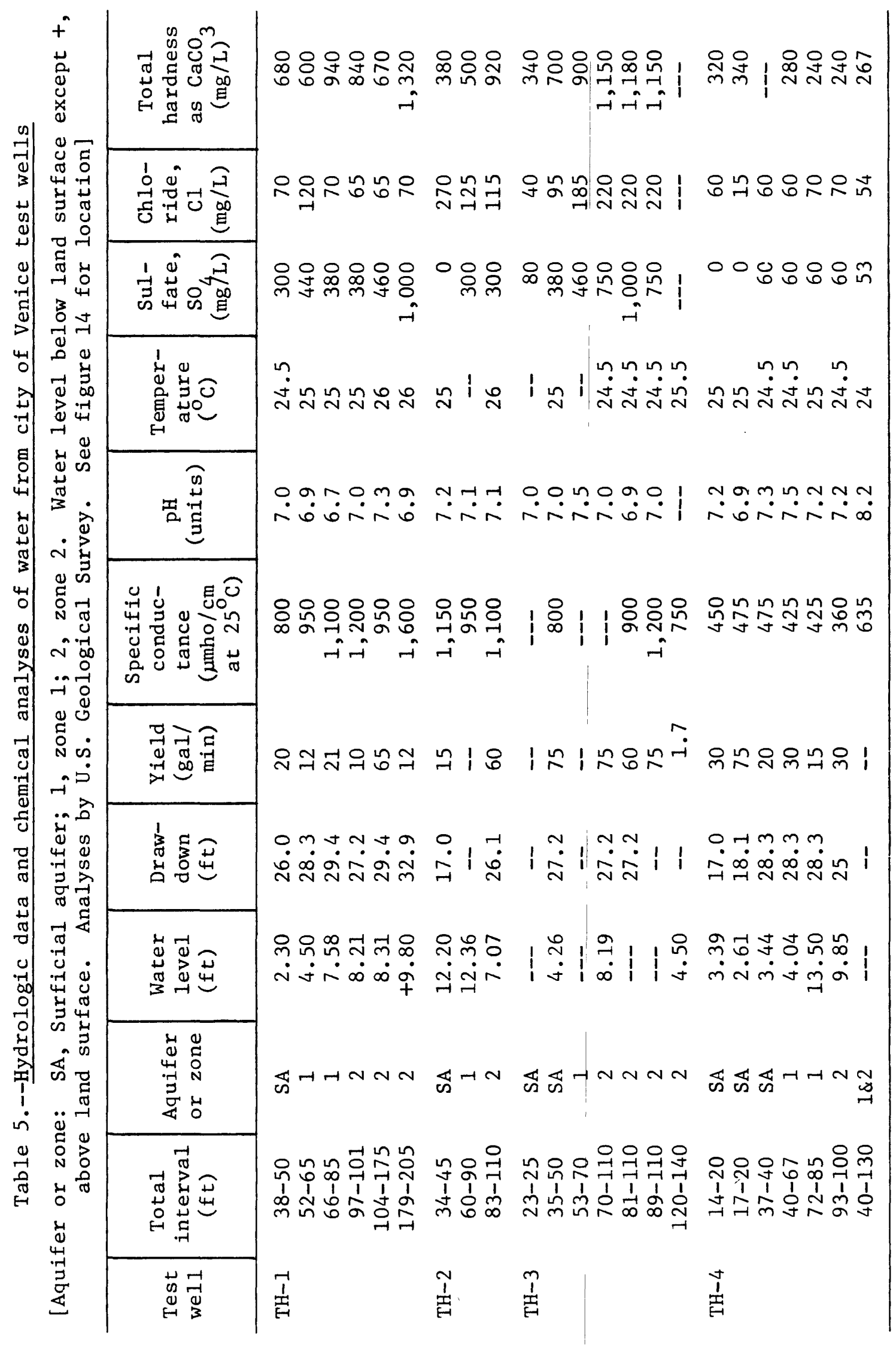


Because of the open-hole well construction method used for many years in the area, obtaining water samples from individual deeper zones is difficult or impossible. Open-hole wells are constructed by installing a few lengths of casing ( 20 to 50 feet) below land surface to prevent pollution from surface drainage and drilling the remainder of the hole without casing. Two or more zones may thus interconnect within the lincased bore. Each zone contributes some water to the well according to the yield characteristics of the zone. Water samples collected at the surface represent a mixture of water from all zones penetrated. A comparison of analyses of water from deeper wells with those from shallower wells shows significantly higher values of dissolved solids with increasing depth (tables 4 and 5).

Figure 11 is a map showing the chloride concentration in water from zone 2 compiled from data collected between 1965 and 1975. High chloride in zone 2 in the Venice area is the result of upward movement of water with high chloride concentrations through well bores from deeper zones. Upward movement also accounts for the northeastern trend of high chloride concentrations in the Forked Creek area. The high chloride concentrations to the south are probably due to chloride in the water that has not been completely flushed from the zone since earlier geologic times when sea levels were higher.

Figure 12 is a map showing the sulfate concentration in water from wells that tap zone 2. Sulfate in water from zone 2 is high, possibly the result of dissolution of sulfate-rich minerals in the zone or upward migration of ground water with high sulfate concentrations from lower zones, either through open well bores, or along some geologic features, such as faults.

The presence of high concentrations of chloride and sulfate in the areas delineated in figures 11 and 12 greatly restricts potential development of ground-water resources from zone 2. Chloride and sulfate are the major problem constituents in ground water from these deeper zones in the study area because they are not readily removed hy simple treatment methods such as aeration, filtration, softening, or chlorination. However, various sophisticated water treatment processes, such as reverse-osmosis, electrodialysis, ion-exchange, flash distillation, or freezing, can remove these constituents to an acceptable level.

The two maps in figure 13 show specific conductance and chloride concentrations of water from zone 2 and deeper zones in a $3-\mathrm{mi}^{2}$ area east of Venice in 1977. Most wells in this area are irrigation wells drilled in the late 1920's for extensive truck-farming operations (Stringfield, 1936). Most of the irrigation wells are about 700 feet deep and are cased from surface to 30 to 60 feet below land surface. The maps (fig. 13) indicate the areal extent of saltwater intrusion in zone 2 in this area when compared with figures 10 and 11 .

The five wells, R01-R05 (fig. 14), that supply water for the city of Venice's reverse-osmosis (RO) plant are between 200 and 650 feet deep and tap zone 2 and deeper zones. The water is slightly saline (table 6) and the average chloride concentration is near the recommended maximum limit of $250 \mathrm{mg} / \mathrm{L}$. Sulfate concentrations, however, greatly exceed the recommended maximum limit of $250 \mathrm{mg} / \mathrm{L}$. Dissolved solids, sulfate, and hardness are reduced to less than recommendeu limits for drinking water by the reverse-osmosis plant. Water from the plant is then blended with water from the city's other well fields. 


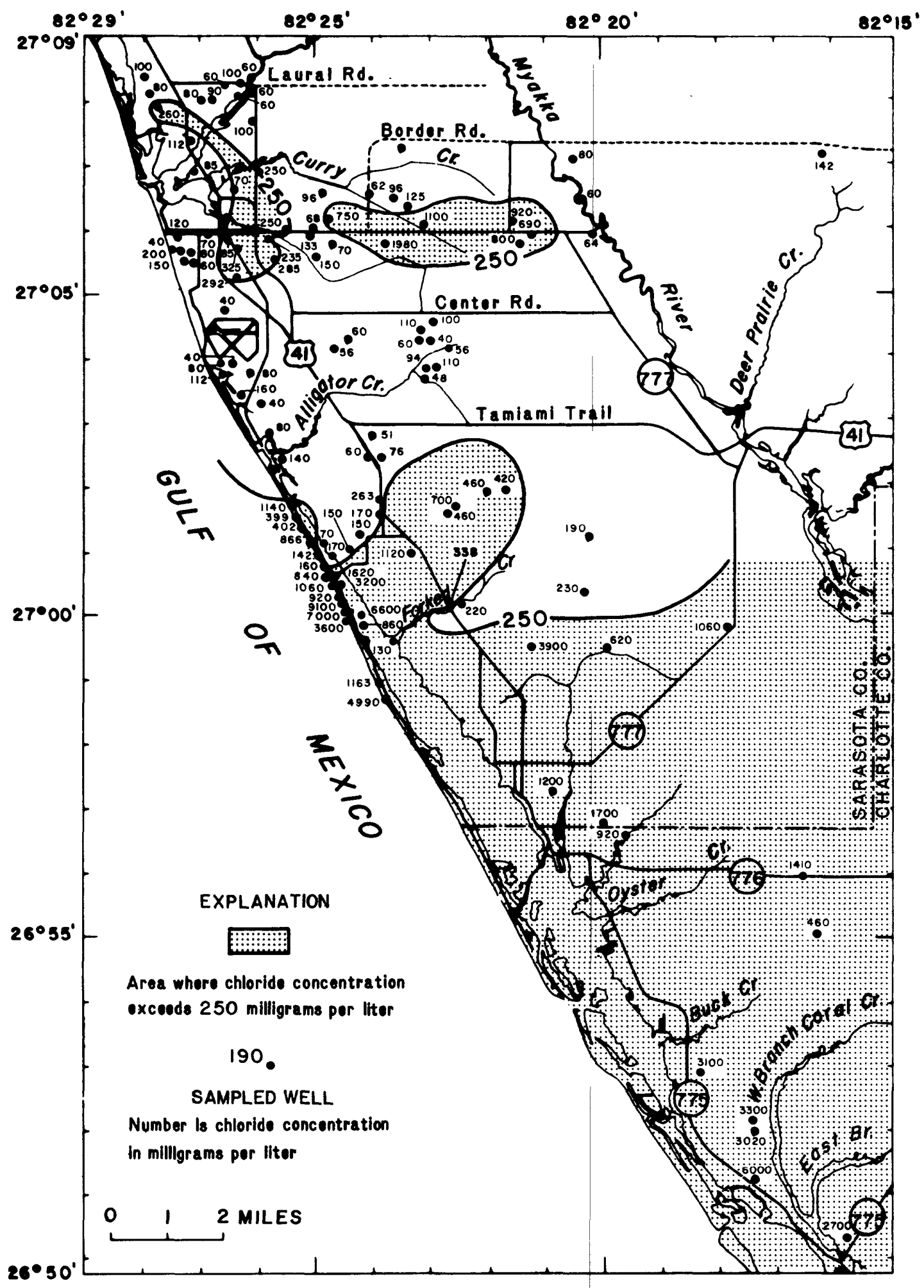

Figure 11.--Areas where chloride concentration in water from zone 2 exceeds 250 milligrams per liter. 


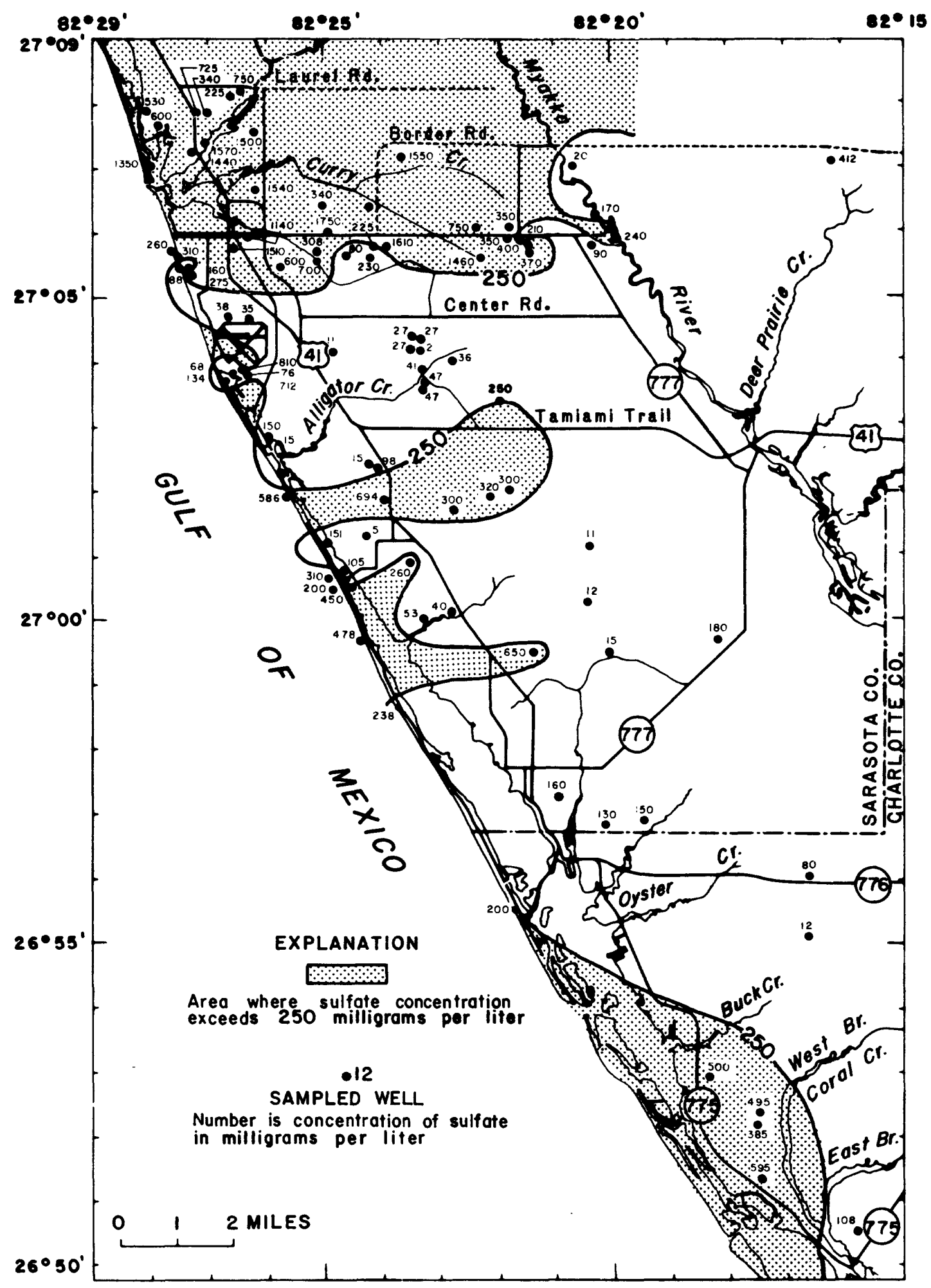

Figure 12.--Areas where sulfate concentration in water from zone 2 exceeds 250 milligrams per liter. 

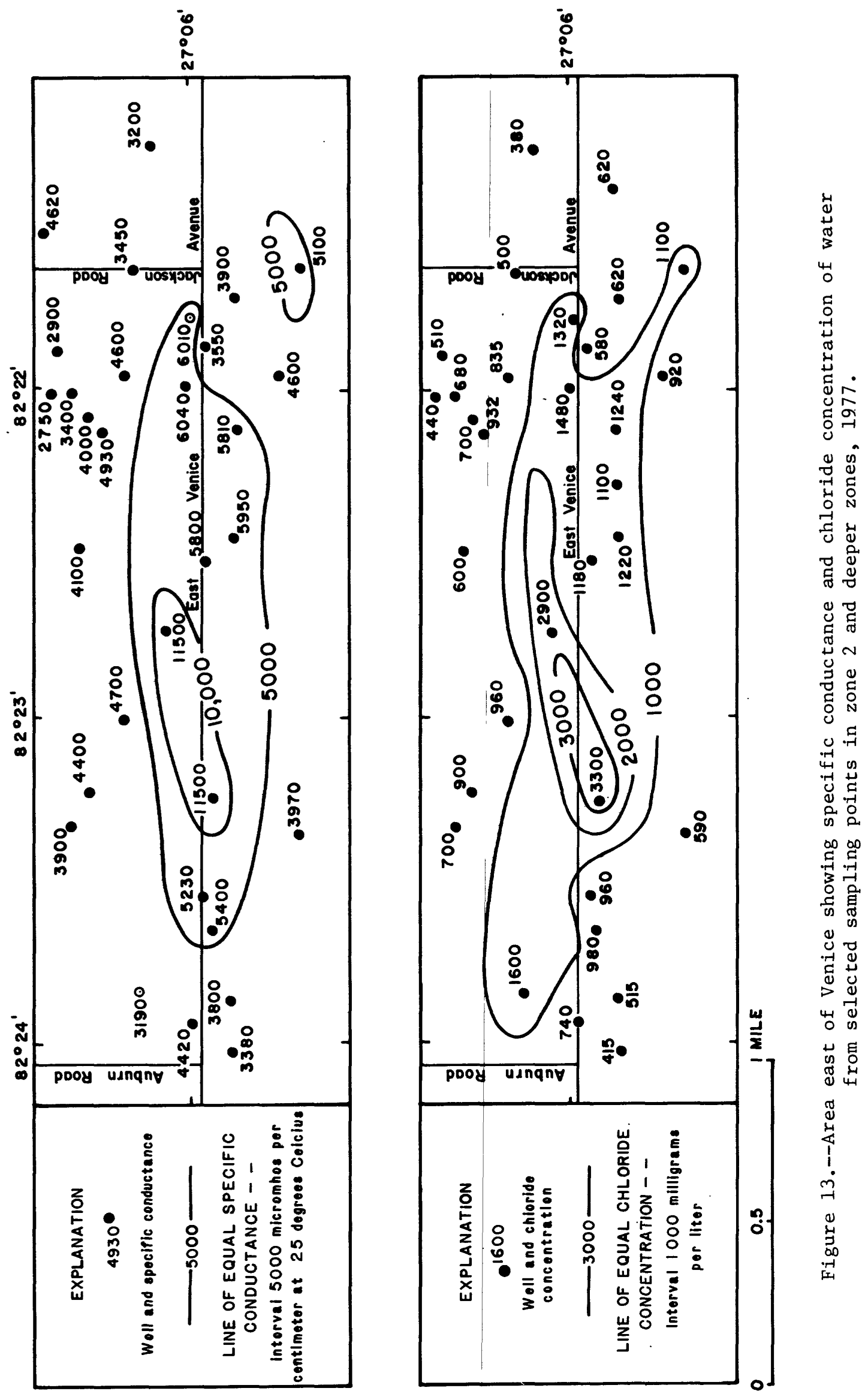


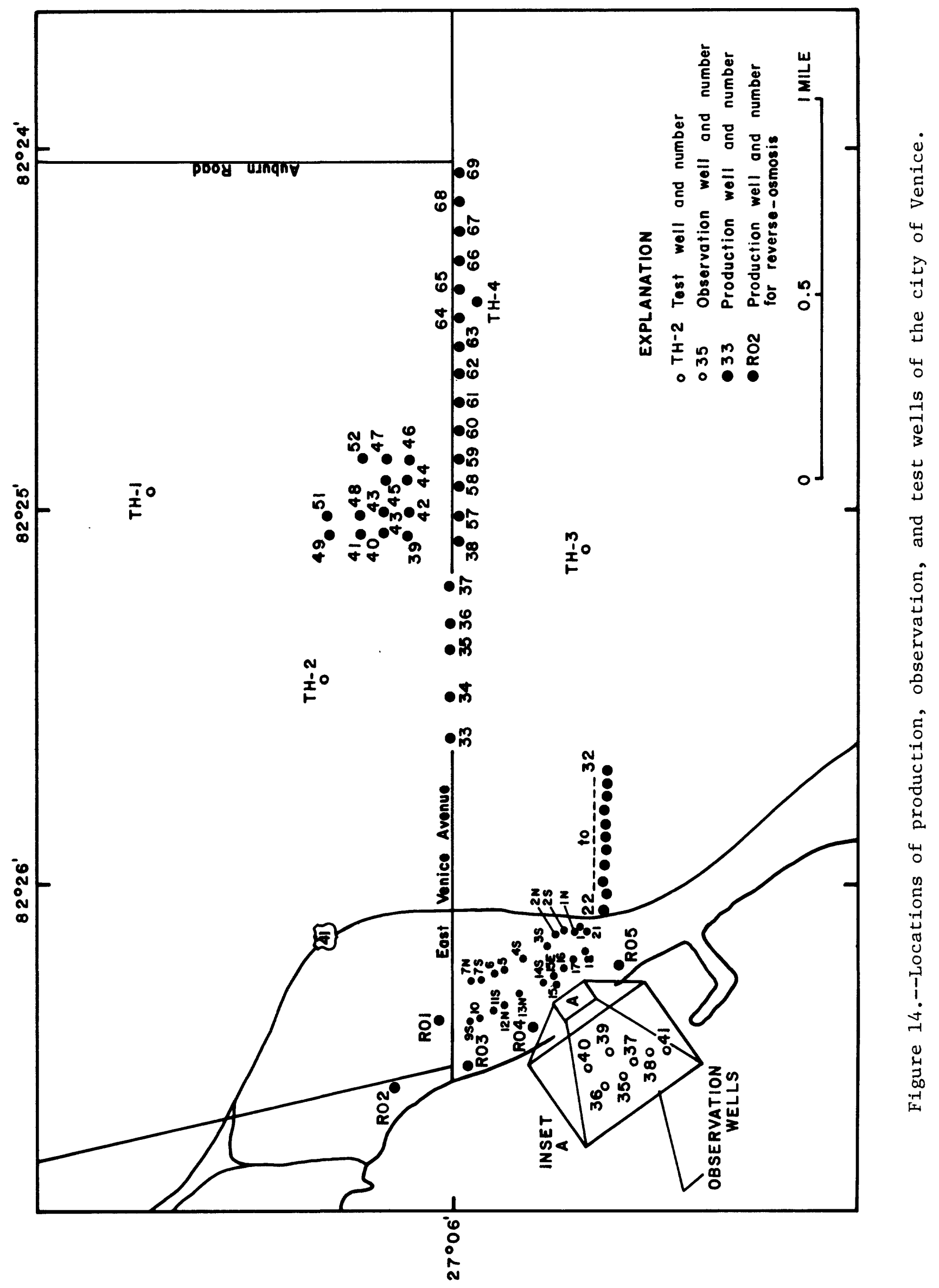




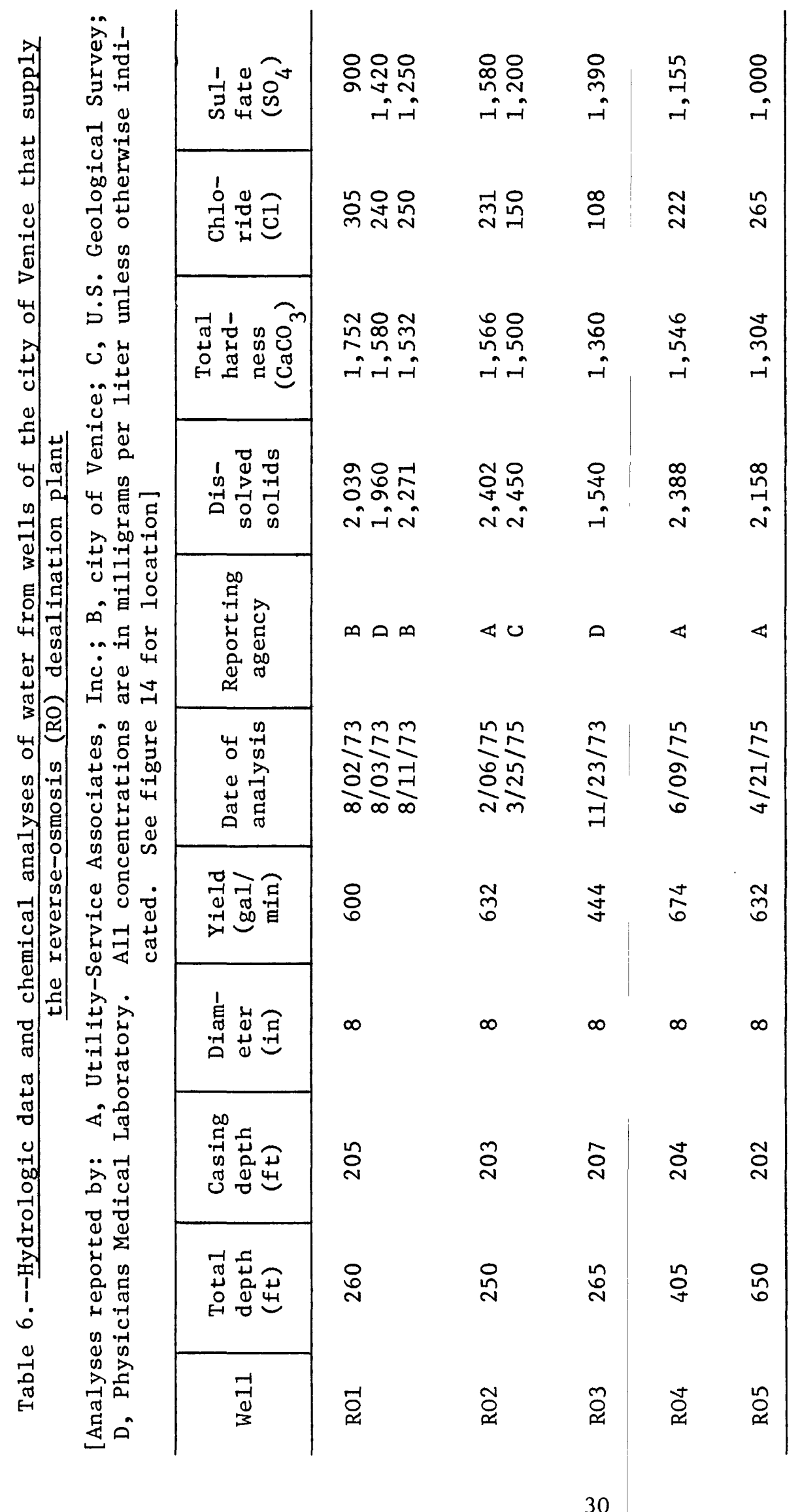


The quality of ground water used as a source for public supply is variable. Analyses of raw and treated water from selected water treatment plants throughout the Venice-Englewood area (fig. 1) are listed in table 7. The number of supply wells, type of water treatment, and other data are also given.

\section{GROUND WATER USE}

The principal uses of ground water in the Venice-Englewood area are for public supply, domestic use, and lawn and garden irrigation. The only industrial use of ground water is for the Venice Hospital, which uses about 30,000 gal/d from the city's supply during hot weather for makeup water in a cooling tower, and for two cement plants, which use a total of about 1,000 gal/d for concrete mix and for washing trucks. Extensive irrigation of truck crops does not occur in the area, although some irrigated gardens of one or two acres exist. Several golf courses are irrigated, but the water comes from a lake or treated wastewater is used.

The 10 water-supply systems in the Venice-Englewood area have a capacity of about $11 \mathrm{Mgal} / \mathrm{d}$ (table 7). Locations of the systems are shown in figure 1. of the 10 systems, only the city of Venice and the Englewood Water District are major public utilities; the remainder are privately owned but franchised to operate within a certain area, usually subdivisions or trailer parks. The 10 water-supply systems obtain water from 220 wells, 7 of which supply water for 2 reverse-osmosis desalination plants. A description of wells for the 10 systems is given in table 8 . The two supply wells for the Rotonda West reverseosmosis system are 140 feet in depth, whereas the five supply wells for the city of Venice reverse-osmosis system range from 250 to 650 feet in depth. Other production wells range in depth from 27 to 209 feet.

A discussion of water use in each water-supply system follows the discussion on well-drilling regulations. Additional information on water use can be found in a report by Leach and Healy (1980).

\section{Well-Drilling Regulations}

Well-drilling regulations adopted by Sarasota County have been directed toward controlling the use of water and determining the aquifer from which water is withdrawn. These regulations require that (1) all wells that penetrate consolidated deposits or rock must be cased with pipe having a minimum diameter of 3 inches and (2) all irrigation or industrial wells that yield more than $50 \mathrm{gal} / \mathrm{min}$ or that have pumps larger than 1.5 horsepower must be cased to at least 300 feet below land surface. The objective of these regulations is to preserve the best quality water, which is within 200 feet of land surface, for domestic use and public water supply.

\section{City of Venice}

In 1975, Venice was one of the fastest growing cities in the area. This growth was partly the result of a change in building practices in response to demand during the 1970's. Construction of single-family dwelling units gave 
way to construction of high-rise condominiums. Numerous multistory buildings, containing as many as 50 dwelling units within one structure, were built along the waterfront. As a result of the increase in population, a tremendous strain on the water-supply and sewer systems occurred within the area. To stay abreast of increased demand on the water-supply system, the city increased the number of wells, doubled the water-treatment plant capacity, and provided additional elevated and ground storage of treated water. However, increased pumping rates and longer periods of pumping by the city's 65 supply wells led to degradation of the quality of water being pumped. Water of poor quality moved both laterally and upward into zone 2. There was also some downward movement of poor quality water from the surficial aquifer into zone 1. In 1973, the Venice Water Board began action to supplement existing supplies by pumpage and treatment of slightly saline ground water using reverse-osmosis. The finished water from the reverseosmosis plant is blended with water from the filtration treatment plant before entering the distribution system.

A test well (RO1) was drilled in the water-plant yard to determine how deep a well must be to yield $500 \mathrm{gal} / \mathrm{min}$. The well was drilled to a depth of 260 feet, flowed $600 \mathrm{gal} / \mathrm{min}$, and the quality of water was suitable for treatment by reverse-osmosis. Subsequently, four additional supply wells were drilled in the vicinity of the plant (table 6). Data on the raw and treated water from supply wells are given in table 7 , along with supplemental data on source, treatment, capacity, and related information. Data on wells are in table 8.

Locations of the city of Venice test, observation, and production wells are shown in figure 14. Pumpage from the city's water-supply system is shown in figure 15. Personnel of the Venice utility system have estimated that nearly onethird of the pumpage demand during the dry period, March through June, is for irrigation of lawns and plantings. The fluctuation in water level of observation well 35 tapping both zones 1 and 2 in response to the withdrawal of water in the Venice area is shown in figure 16.

\section{Englewood Water District}

The Englewood Water District was created by a special act of the Florida Legislature on June 4, 1959, to provide water and sewer service to the residents within the District in Sarasota and Charlotte Counties. The act has since been amended several times to increase the area served by the District.

The first 20 water-supply wells (12 to 30 and $A 1$ ) were drilled between November 1962 and March 1963, and water was first delivered to customers in December 1964. Figure 17 shows the increase in demand for water from the system since 1964. Figure 18 shows the locations of the production and some of the observation wells for the Englewood Water District; table 7 gives the plant data and water analyses; and table 8 gives the well records.

In 1969 , five new wells ( $1 \mathrm{~A}$ to $5 \mathrm{~A}$ ) were added in the old well-field area south of Highway 777 and a test-drilling program was started to locate an additional $1.5 \mathrm{Mgal} / \mathrm{d}$ of water that could be treated by the lime-soda method. Using data from 27 test wells, a site was located for a new well field. The field, consisting of 14 production wells ( 31 to 44 ), was constructed about 1 mile north and east of the plant at the old field (fig. 18). The well field and expanded treatment plant were put in operation in 1973. In 1974, four wells (45 to 48) were added to the well field. 


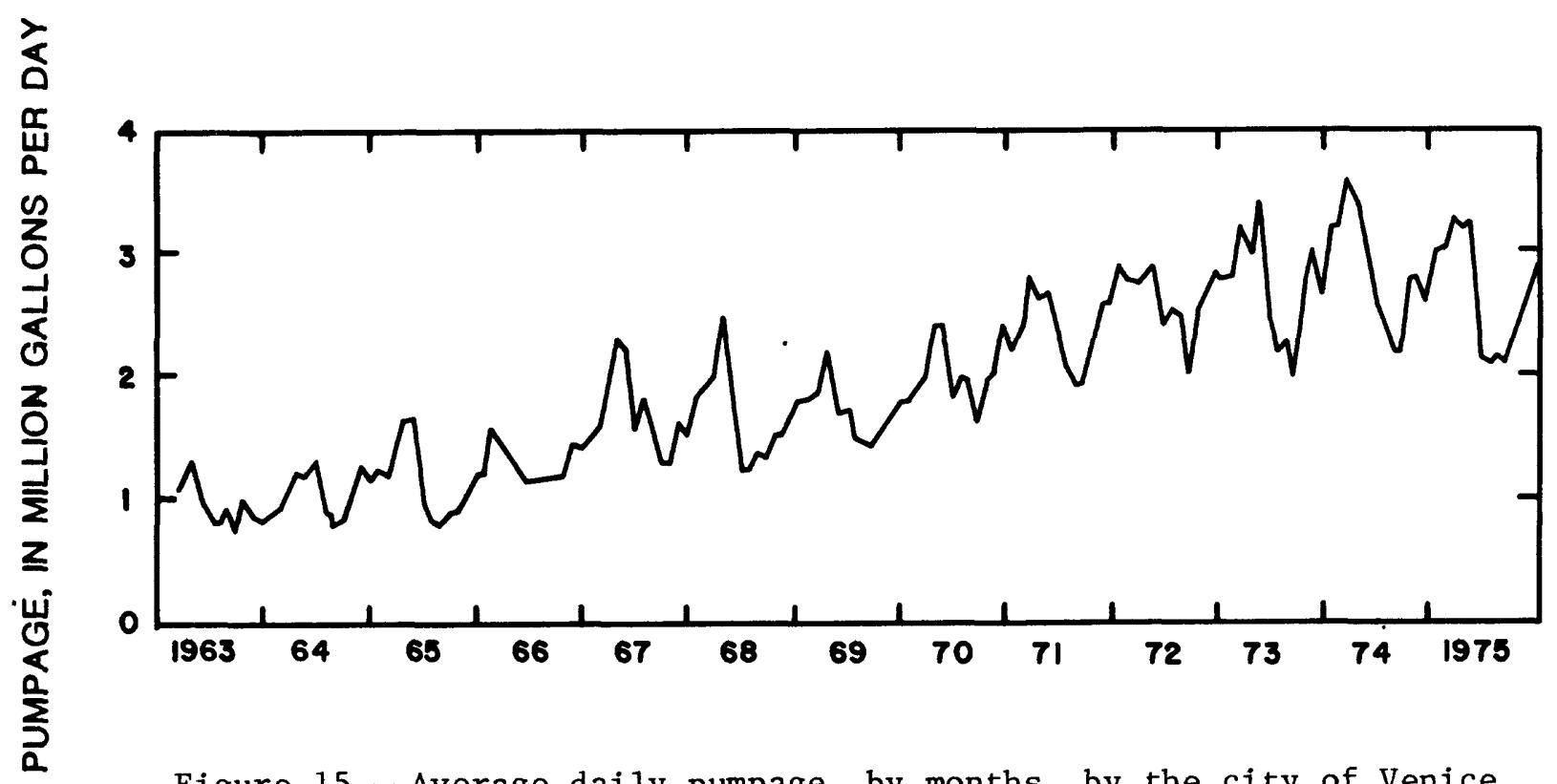

Figure 15.--Average daily pumpage, by months, by the city of Venice, 1963-75.

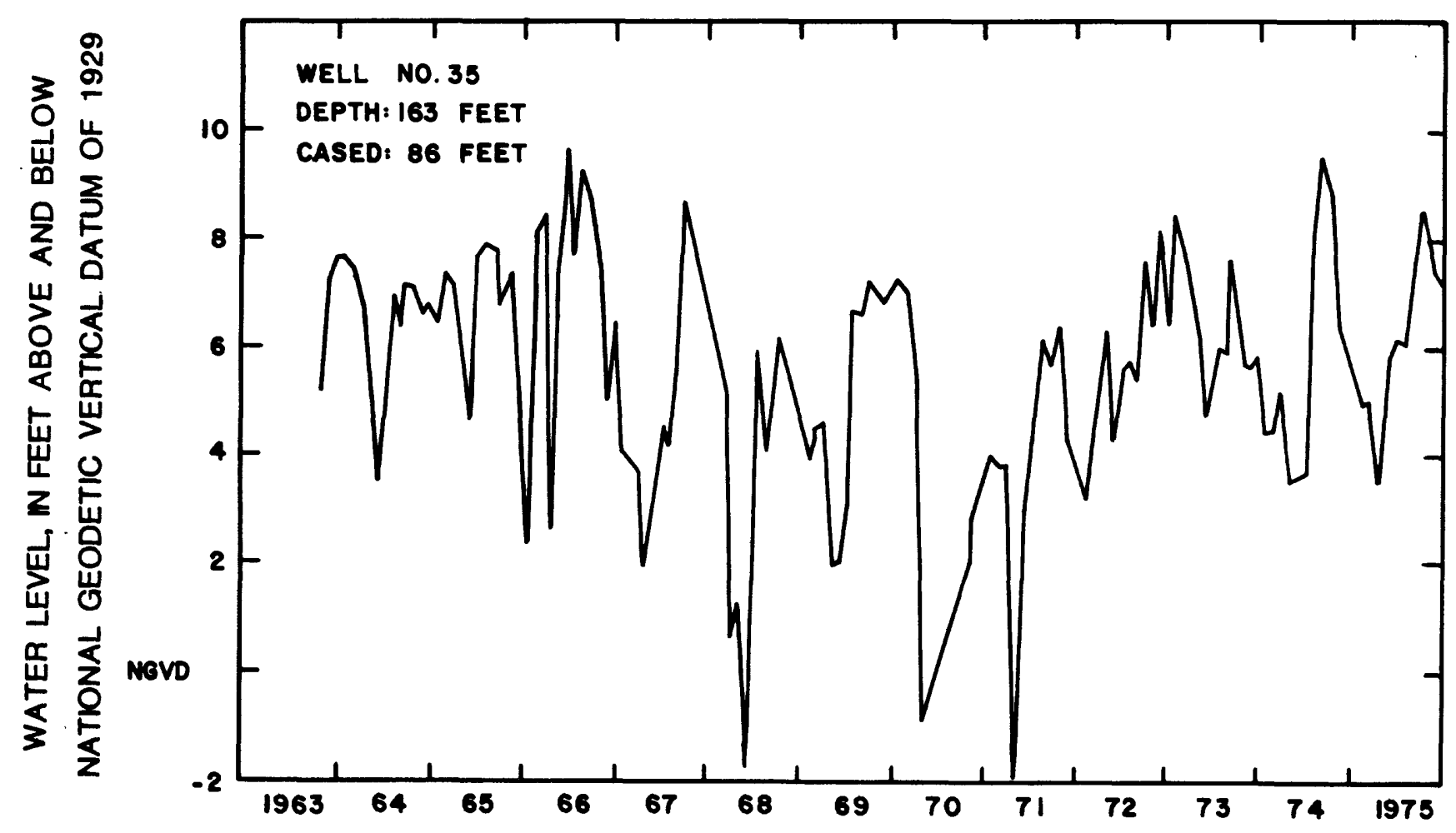

Figure 16.--Water level in observation well 35 near the city of Venice well field, 1963-75. 


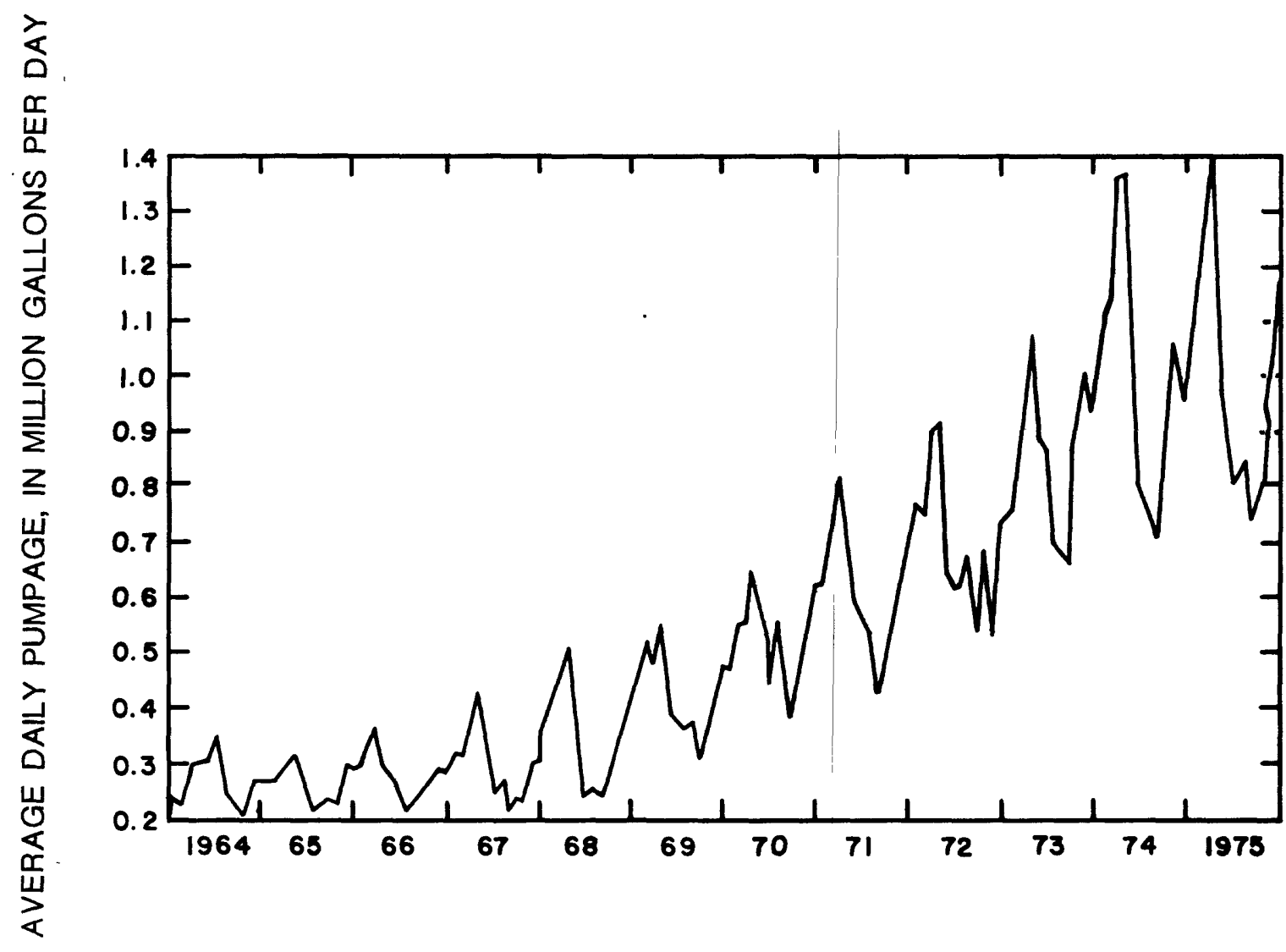

Figure 17.--Average daily pumpage, by months, by the Englewood Water District, 1964-75.

In 1974 and 1975, 12 additional test wells were drilled near Englewood. The locations of these test wells are shown in figure 19 and depths of the wells are listed in table 4. The two wells to the south (ROI and RO2) were drilled to determine the quality and quantity of water available for possible supply to a reverse-osmosis desalination plant.

Hydrographs of water levels in observations wells TW6, TW8, and TW14 tapping zone 1 in the Englewood well field are shown in figure 20. The relation between pumpage and water levels in the area is indicated by the declines that occur during heavy use in the relatively dry winter and spring months and the recovery during the wet summer months when demand is less. Water levels failed to recover during the summer and fall of 1973 due to heavy pumpage during that period (fig. 17).

\section{Private Water Systems}

Sarasota County requires that new housing developments provide water and sewer services to each development. This has led to the creation of several privately owned utility franchises throughout the county. Most private systems provide water that has been aerated and chlorinated. Several hundred thousand gallons of water are furnished each day from the small utility plants to mobile home parks and small subdivisions. Eight private utilities are discussed briefly in this report--one in Charlotte County and seven in Sarasota County (fig. 1). 


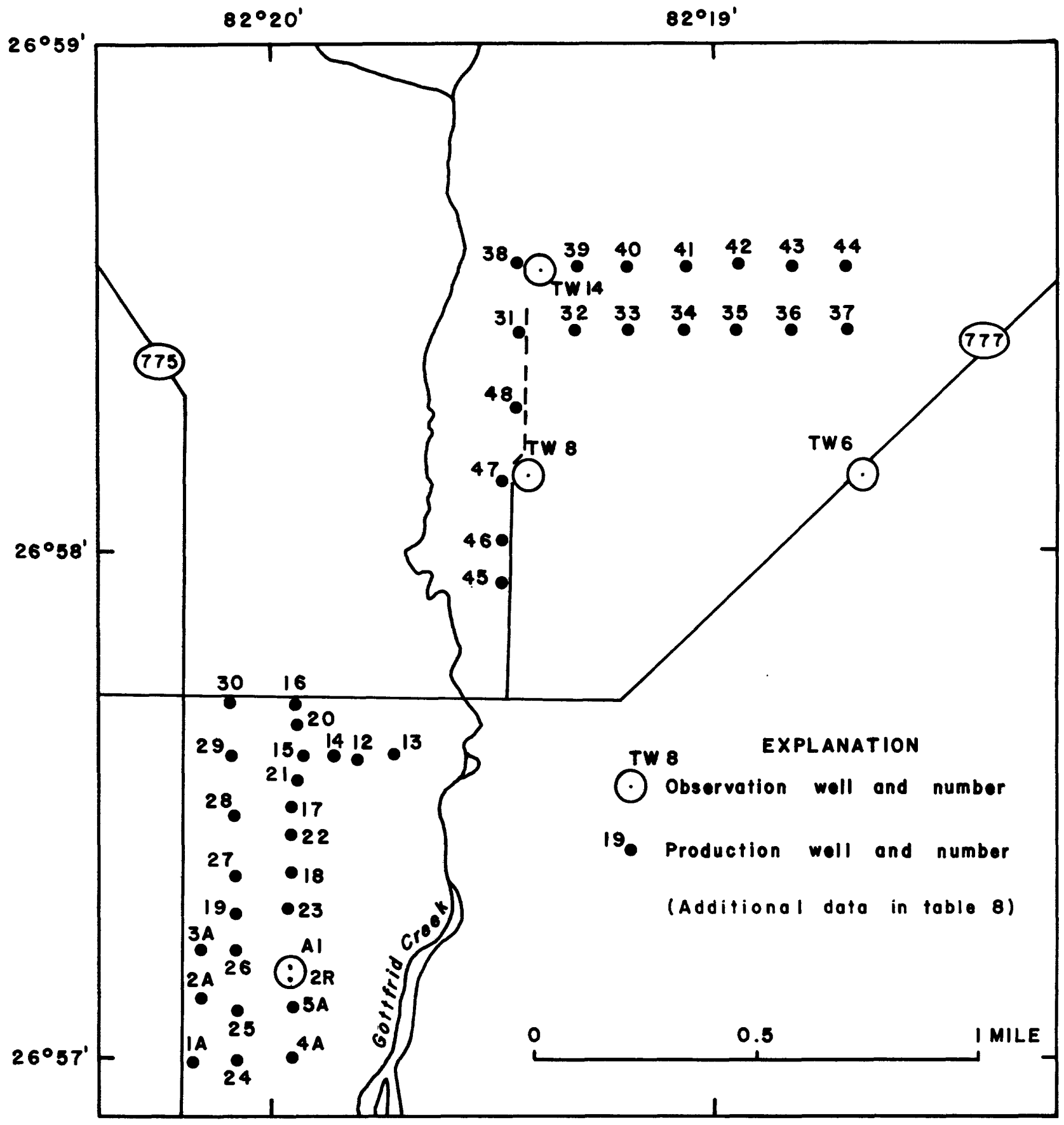

Figure 18.--Locations of production wells and selected observation wells of the Englewood Water District. 


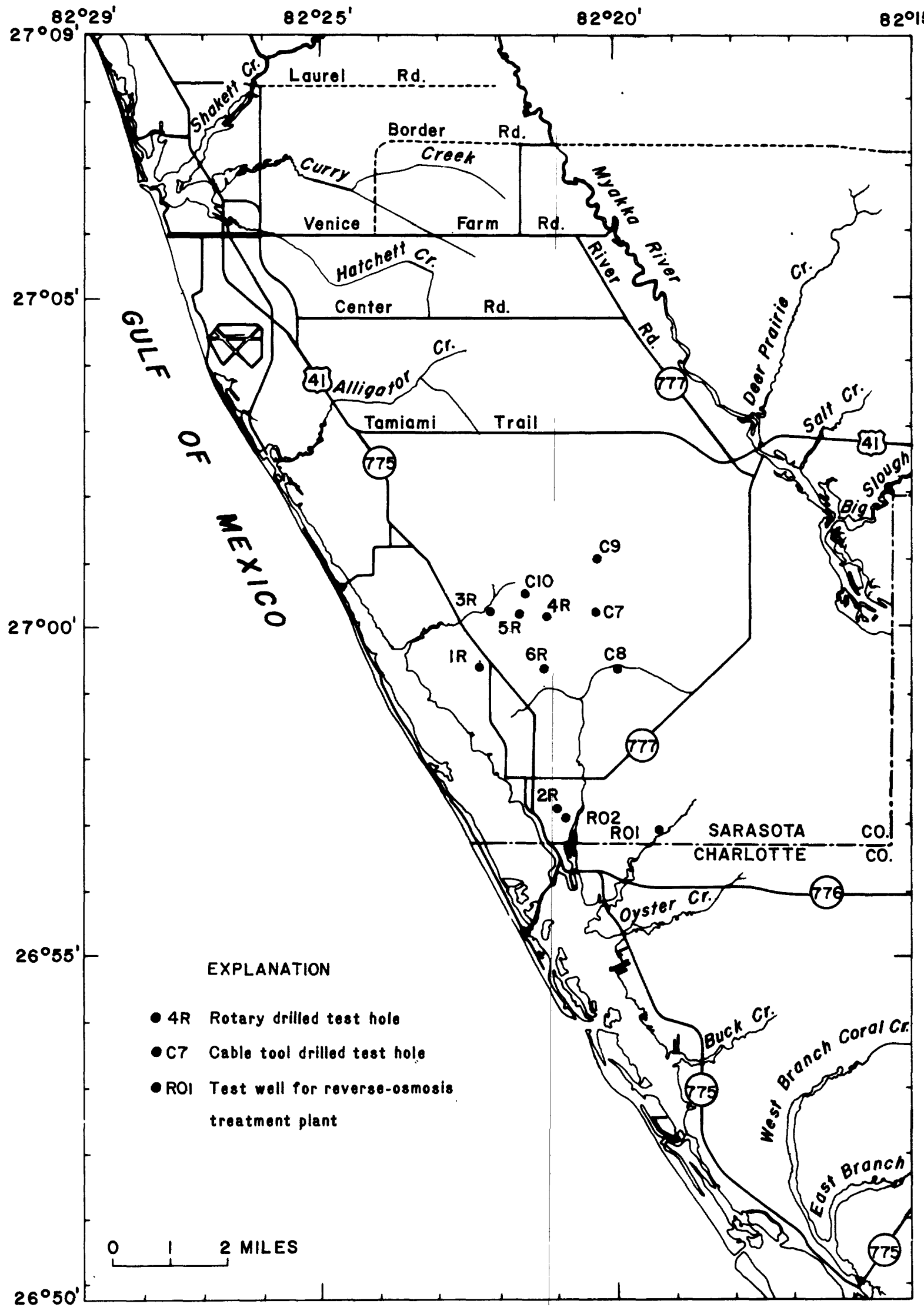

Figure 19.--Locations of test wells near Englewood. 


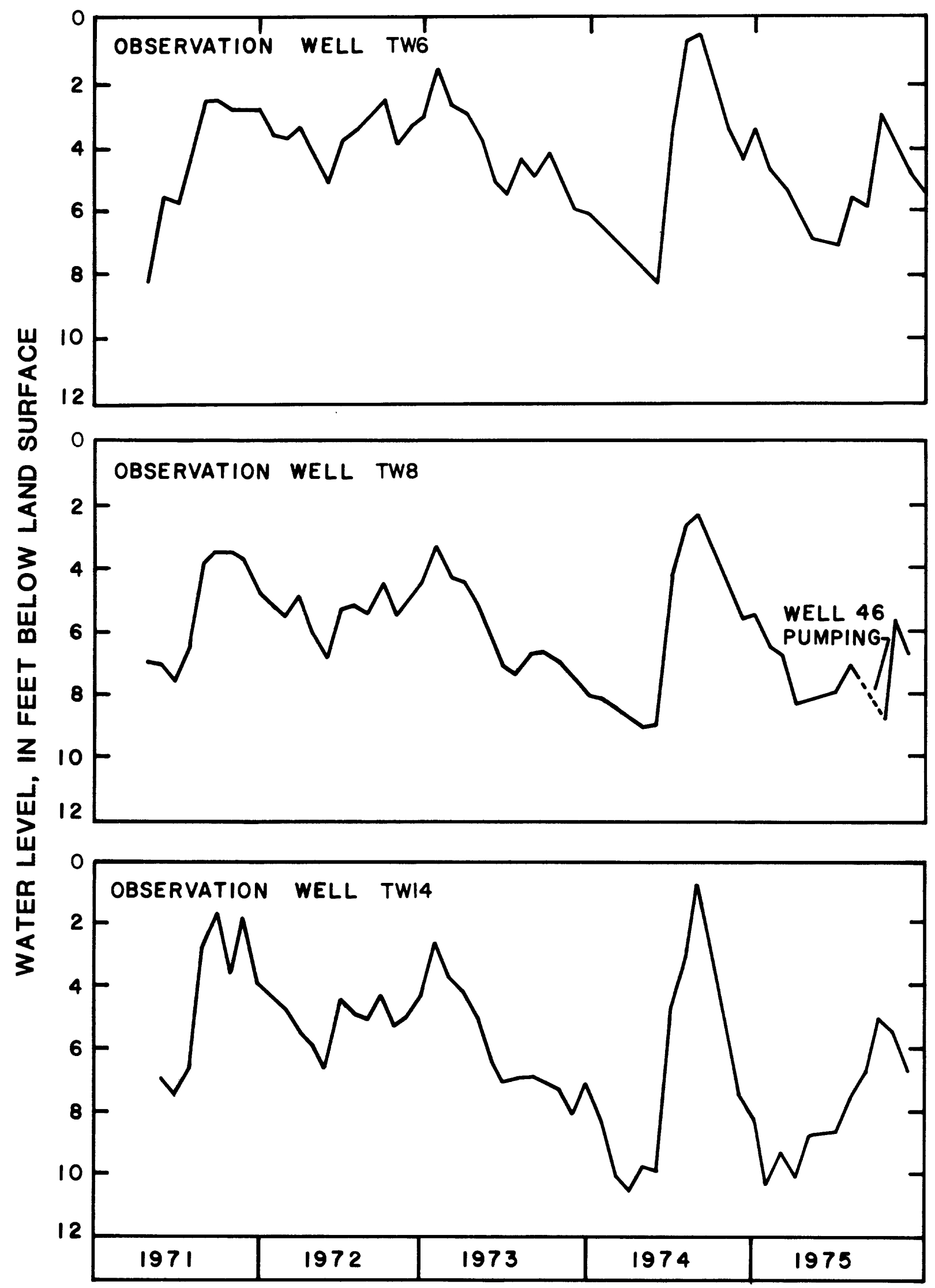

Figure 20.--Water levels in observation we11s TW6, TW8, and TW14 of the Englewood Water District, 1971-75. 
Rotunda West, in Charlotte County just south of the Englewood Water District, was started in 1953 as the Cape Haze water-supply system. The original system used water from a shell bed about 20 feet below land surface and treated it in a lime-soda plant to remove color and hardness. A reservoir upstream of the low-level dam on Coral Creek served as a backup supply. The shell bed continues to provide water to that plant.

Beginning in 1971, the Rotunda West utility was expanded to provide water for a planned community of 50,000 people. Test drilling indicated that adequate quantities of brackish ground water were available in zone 1 and in the upper part of zone 2 to supply a $0.5 \mathrm{Mgal} / \mathrm{d}$ reverse-osmosis plant. Such a plant was completed in 1972 and put on-line in addition to the old plant with a combined capacity of $0.788 \mathrm{Mgal} / \mathrm{d}$. Data on the Rotunda West system are in tables 7 and 8.

Thro small private systems are at Japanese Gardens, a mobile home park between Englewood and Venice, and at Ramblers Rest, a campground (fig. 1). The private system at Venice Gardens consists of three individual systems: Venice Gardens plant 1 (well field 1) and Venice Gardens plant 2 (well field 2), which are interconnected, and Venice East plant (well field), which operates independently. Figure 21 shows the locations of these three well fields. The wells are listed in table 8 . Water treatment used in these systems consists of aeration and chlorination. Venice campground provides water for campers and Venice Ranch trailer park provides water to residents (fig. 1 and tables 7 and 8). Both systems are treated by aeration and chlorination. All of these private utilities use ground water from zone 1 and in some cases from the upper part of zone 2, just below the "Venice clay."

\section{Domestic We1ls}

Until 1970, most domestic wells were small diameter wells, usually cased with 2-inch galvanized pipe to a depth necessary to prevent sand and surface flow from entering the well. Since 1970, well casings must be at least 3 inches in diameter, except for wells tapping only the surficial aquifer. The deeper wells are generally completed open hole in the limestone and clay beds. Many of the deeper domestic wells produce $60 \mathrm{gal} / \mathrm{min}$. Domestic wells are used principal$1 y$ for watering lawns and tropical plantings. Approximately 7,000 domestic or small irrigation wells have been drilled in south Sarasota County since 1963 when the Sarasota County Health Department started collecting data on well completions.

Outside of areas served by the public-supply systems, individual domestic wells generally supply water that may be treated with home water-treatment equipment. Depending on the location, domestic wells range from 12 to 150 feet in depth. Well-point systems that tap the surficial aquifer are generally from 12 to 30 feet deep. The deeper wells--those 40 to 150 feet deep--have 20 to 60 feet of casing. Most domestic wells are 60 to 100 feet deep. Minimum yields from a well point are about $5 \mathrm{gal} / \mathrm{min}$ and from a deeper well about $20 \mathrm{gal} / \mathrm{min}$. Careful drilling and particular attention to placement and cementing of casing often improve the quality of water produced in a well, although well yields are sometimes reduced by casing off producing intervals. Most domestic wells in the southern part of the area are completed in zone 1; deeper wells in the north also penetrate the upper part of zone 2 . 


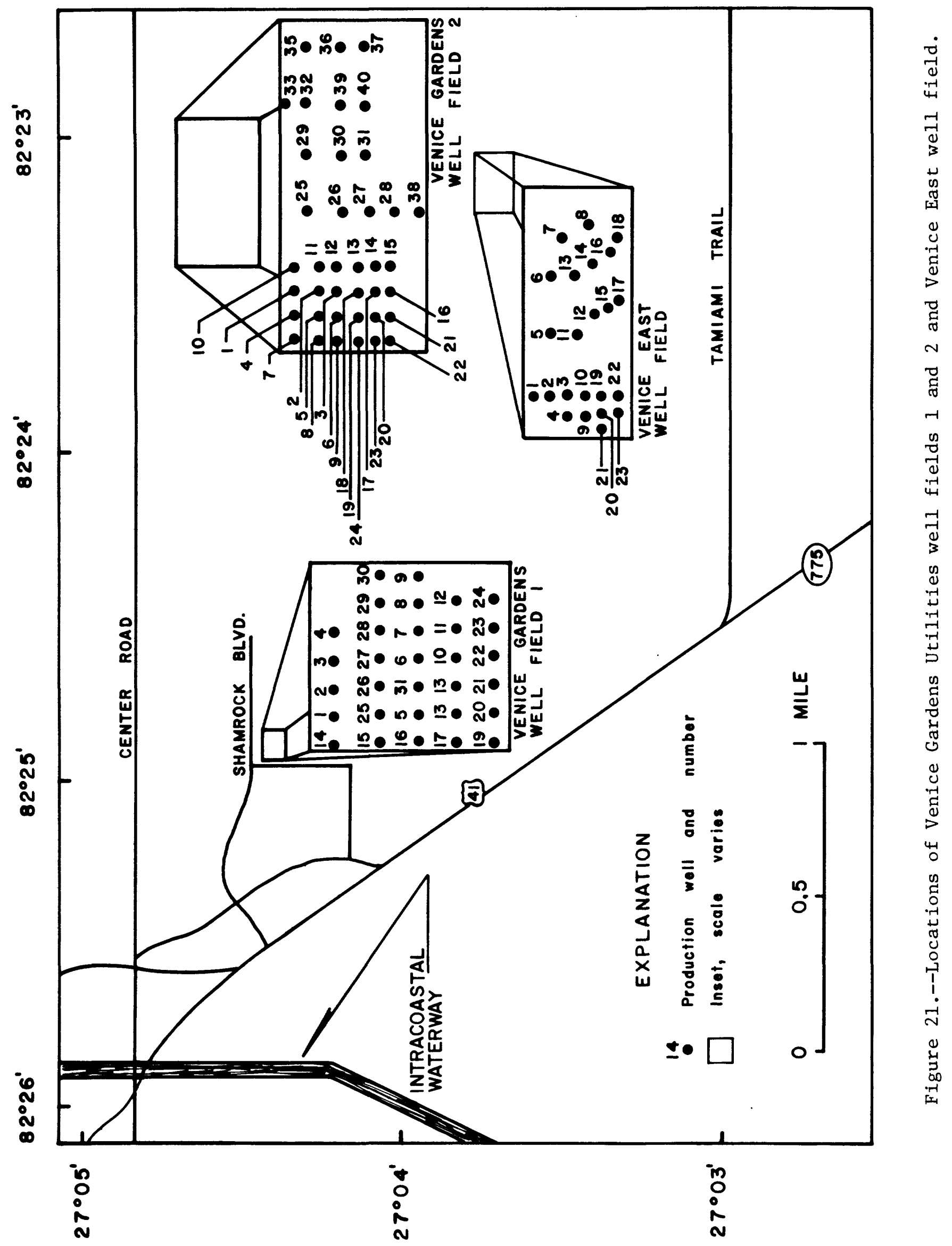




\section{Irrigation}

One of the early uses of water in the Venice-Englewood area, principally east of Venice, was for irrigation of truck crops. Over a period of years, saline water moved upward from deeper zones, and the dissolved-solids concentration of the water produced by these wells became too high for plant tolerance. Most of the land is now used for other agricultural purposes, principally pasture.

We11-drilling regulations in Sarasota County now require that commercial irrigation wells be cased to a minimum of 300 feet. As a result, irrigation water in the county is now withdrawn for the most part from the lower part of zone 2 and deeper. In the Venice-Englewood area, water from these zones is too highly mineralized for irrigation purposes.

\section{Industria1}

The principal industrial use of water in the Venice-Englewood area is for air conditioning at the Venice Hospital. About 30,000 gal/d from zones 1 and 2 are used as makeup water for a cooling tower. Sarasota County requires that, for any new direct cycle air-conditioning system, the water must be returned in a closed system to a zone deeper than that from which the water is obtained. Smaller amounts, 1,000 gal/d, are used in the cement-mixing industry and for washing trucks. This water is also pumped from zones 1 and 2 .

\section{SUMMARY}

In the Venice-Englewood area, ground water from the surficial aquifer and from one or more underlying permeable zones is the principal source of water for municipal, irrigation, and domestic supplies. The deeper permeable zones occur within a series of interbedded sand, sandy clays, clays, and limestones and extend from depths of about 50 to more than 1,000 feet below land surface.

The surficial aquifer consists of sand and shell beds extending from land surface to depths ranging from 5 to 60 feet below land surface. Properly designed wells that tap this aquifer yield from 5 to $85 \mathrm{gal} / \mathrm{min}$. In most of the area, water from the surficial aquifer is potable. However, in the southern and coastal parts of the area where the land surface has been inundated by storm tides, the aquifer contains saline water and is not used as a source of water supply. The surficial aquifer is extensively used for domestic water supplies and provides part of the water supply for the Englewood Water District.

Zone 1 is composed of limestone, clays, sands, and shell beds of the Tamiami Formation and is confined at the base by a waxy, green clay locally called "Venice clay." Zone 1 is the principal source of water for domestic and municipal supply within the area. Wells may yield up to $150 \mathrm{gal} / \mathrm{min}$ from the thicker limestone and shell sequences. In most areas, particularly between State Highways 775 and 777 and U.S. Highway 41, water from zone 1 meets DER chemical quality standards 
for drinking water. Although potable water is generally available from this zone, the zone is contaminated by saline water in some areas. Saline water in zone 1 has two possible sources: residual seawater. remaining in the aquifer from a period of higher sea levels in the geologic past; and water that has leaked upward mostly from the uncased sections of deep wells constructed prior to strict drilling regulations. Protection of zone 1 from further degradation from uncased wells would require extensive rehabilitation or proper plugging of old wells.

Zone 2 consists of the interbedded limestone, clay, and sandy clay in the upper part of the Hawthorn Formation. This zone generally contains slightly to moderately saline water. The water in some areas contains high concentrations of sulfate and chloride ranging from 250 to more than $500 \mathrm{mg} / \mathrm{L}$. Water in this zone, however, is suitable for treatment by reverse-osmosis. The city of Venice utilizes the water treated by reverse-osmosis from zone 2 for part of its municipal supply. In part of the area, water from this zone is used for irrigation. The artesian head in zone 2 is above land surface and considerably higher than the head in zone 1 . In wells open to both zones, saline water migrates upward from zone 2 into zone 1 and moves laterally, causing degradation of the water quality, particularly in the areas east of the city of Venice.

Zone 3, which consists of the lower part of the Hawthorn Formation and the Tampa Formation, contains moderately to very saline water throughout the area. Because of the high salinity of water in this zone and in zones 4 and 5 , wells are not normally drilled to zone 3 or deeper except to provide water for treatment by desalination processes.

The 10 water-supply systems in the Venice-Englewood area have a capacity of about $11 \mathrm{Mgal} / \mathrm{d}$. Only the city of Venice and the Englewood Water District are major public utilities. In 1975, maximum average daily pumpage was about $3 \mathrm{Mgal} / \mathrm{d}$ for the city of Venice and about $1.4 \mathrm{Mgal} / \mathrm{d}$ for the Englewood Water District. 


\section{SELECTED REFERENCES}

Clark, W. E., 1964, Possibility of saltwater leakage from proposed intracoastal waterway near Venice, Florida, well field: Florida Geological Survey Report of Investigations $38,33 \mathrm{p}$.

Eppert, H. C., 1966, Stratigraphy of the Upper Miocene deposits in Sarasota County, Florida: Tulane Studies in Geology, v. 4, no. 2, p. 49-61.

F1ippo, H. N., Jr., and Joyner, B. F., 1968, Low streamflow in the Myakka River Basin area in Florida: Florida Geological Survey Report of Investigations $53,34 \mathrm{p}$.

Florida Department of State, 1977, Rules of the Department of Environmental Regulation, water supplies, Chapter 17-22, in Florida Administrative Code: Ta1lahassee.

Joyner, B. F., and Sutcliffe, Horace, Jr., 1976, Water resources of the Myakka River Basin area, southwest Florida: U.S. Geological Survey Water-Resources Investigations $76-58,87 \mathrm{p}$.

Leach, S. D., and Healy, H. G., 1980, Estimated water use in Florida, 1977: U.S. Geological Survey Water-Resources Investigations 79-112, 76 p.

Ryder, P. D., Laughlin, C. P., and Mills, L. R., 1977a, Potentiometric surface of Floridan aquifer, Southwest Florida Water Management District, September 1976: U.S. Geological Survey Open-File Report 77-353.

1977b, Potentiometric surface of Floridan aquifer, Southwest Florida Water Management District and adjacent areas, May 1977: U.S. Geological Survey Open-File Report 77-552,

Stringfield, V. T., 1933, Ground-water resources of Sarasota County: Florida Geological Survey, Twenty-third-twenty-fourth Annual Report, p. 121-194.

1936, Artesian water in the Florida peninsula: U.S. Geological Survey Water-Supply Paper 773-C, p. 115-195.

1966, Artesian water in Tertiary limestone in the southeastern states: U.S. Geological Survey Professional Paper 517, 226 p.

Sutcliffe, Horace, Jr., 1975, Appraisal of the water resources of Charlotte County, Florida: Florida Bureau of Geology Report of Investigations 78, $53 \mathrm{p}$.

Sutcliffe, Horace, Jr., and Joyner, B. F., 1968, Test well exploration in the Myakka River Basin area, Florida: Florida State Board of Conservation, Division of Geology Information Circular 56, $61 \mathrm{p}$.

Thompson, R. B., editor, 1977, Florida Statistical Abstract 1977, 12th Annual edition, University Presses of Florida, Gainesville, 653 p. 
Table 7.--Analyses of raw and treated water from selected water-treatment plants in the Venice-Englewood area

[Except for $\mathrm{pH}$, color, turbidity, and specific conductance, constituents are reported as milligrams per liter or parts per million, depending on the practice at individual private laboratories. Analyses by the U.S. Geological Survey are reported as milligrams per liter, mg/L.]

Location (fig. 1)

Supply source

Treatment

Plant capacity

Storage capacity and type Service connections Analysis by
City of Venice.

11 observation and test we1ls; 70 production wells (including 5 RO wells).

Reverse-osmosis (RO), $1 \mathrm{Mgal} / \mathrm{d}$; aeration, coagulation, filtration, chlorination, $3 \mathrm{Mgal} / \mathrm{d}$.

4.0 Mgal/d.

$1.6 \mathrm{Mgal}$, treated.

4,800 (1977).

1977, Venice Water Department; 1972, Venice Water Department; 1975, U.S. Geological Survey.

\begin{tabular}{|c|c|c|c|}
\hline Constituent & $\begin{array}{l}1971 \\
\text { (treated) }\end{array}$ & $\begin{array}{l}1972 \\
\text { (treated) }\end{array}$ & $\begin{array}{l}1975 \\
\text { (raw } \\
\text { composite) }\end{array}$ \\
\hline $\begin{array}{l}\text { Silica }\left(\mathrm{SiO}_{2}\right) \\
\text { Calcium }(\mathrm{Ca})^{-} \\
\text {Magnesium (Mg) } \\
\text { Sodium (Na) } \\
\text { Potassium (K) }\end{array}$ & $\begin{array}{r}168 \\
31 \\
15 \\
--\end{array}$ & $\begin{array}{r}-- \\
126 \\
44 \\
32 \\
--\end{array}$ & $\begin{array}{r}21 \\
170 \\
44 \\
64 \\
2.9\end{array}$ \\
\hline $\begin{array}{l}\text { Strontium }(\mathrm{Sr}) \\
\text { Bicarbonate }\left(\mathrm{HCO}_{3}\right) \\
\text { Sulfate }\left(\mathrm{SO}_{4}\right) \\
\text { Chloride }(\mathrm{C} 1) \\
\text { Fluoride (F) }\end{array}$ & $\begin{array}{r}337 \\
250 \\
30 \\
0\end{array}$ & $\begin{array}{r}-- \\
254 \\
225 \\
90 \\
--\end{array}$ & $\begin{array}{r}3 \\
278 \\
350 \\
100 \\
0.7\end{array}$ \\
\hline $\begin{array}{l}\text { Nitrate }\left(\mathrm{NO}_{3}-\mathrm{N}\right) \\
\text { Nitrite }\left(\mathrm{NO}_{2}-\mathrm{N}\right) \\
\text { Nitrogen, organic }(\mathrm{N}) \\
\text { Ammonia, total }\left(\mathrm{NH}_{4}-\mathrm{N}\right) \\
\text { Iron }(\mathrm{Fe})\end{array}$ & $\begin{array}{l}-- \\
-- \\
-- \\
- \\
.65\end{array}$ & $\begin{array}{l}-- \\
-- \\
-- \\
-- \\
0.3\end{array}$ & $\begin{array}{l}0.00 \\
0.00 \\
0.51 \\
0.35 \\
0.5\end{array}$ \\
\hline $\begin{array}{l}\text { Phosphorus, total (P) } \\
\text { Dissolved solids } \\
\text { Total hardness (as } \mathrm{CaCO}_{3} \text { ) } \\
\text { Noncarbonate hardness (as } \mathrm{CaCO}_{3} \text { ) } \\
\text { Alkalinity (as } \mathrm{CaCO}_{3} \text { ) }\end{array}$ & $\begin{array}{l}-- \\
770 \\
550 \\
274 \\
276\end{array}$ & $\begin{array}{l}-- \\
745 \\
500 \\
292 \\
208\end{array}$ & $\begin{array}{l}0.04 \\
990 \\
610 \\
380 \\
228\end{array}$ \\
\hline $\begin{array}{l}\mathrm{pH} \text { (units) } \\
\text { Specific conductance }(\mu \mathrm{mho} / \mathrm{cm} \text { at }\end{array}$ & 6.8 & 6.8 & 7.6 \\
\hline $\begin{array}{l}\left.25^{\circ} \mathrm{C}\right) \\
\text { Color (Pt-Co units) } \\
\text { Temperature }\left({ }^{\mathrm{C}} \mathrm{C}\right)\end{array}$ & $\begin{array}{l}-- \\
--\end{array}$ & $\begin{array}{ll}-- \\
-- \\
--\end{array}$ & $\begin{array}{r}1,320 \\
45 \\
--\end{array}$ \\
\hline $\begin{array}{l}\text { Turbidity (JTU) } \\
\text { Carbon, organic, total (C) } \\
\text { Orthophosphate, total }\left(\mathrm{PO}_{4}-\mathrm{P}\right)\end{array}$ & $\begin{array}{l}-- \\
--\end{array}$ & -- & $\begin{array}{l}9 \\
10 \\
0.03\end{array}$ \\
\hline
\end{tabular}


Table 7.--Analyses of raw and treated water from selected water-treatment plants in the Venice-Englewood area--Continued

Location (fig. 1)

Supply source

Englewood Water District.

Treatment

41 wells.

Aeration, nation.

Plant capacity

$3.0 \mathrm{Mgal} / \mathrm{d}$.

Storage capacity and type

$0.1 \mathrm{Mgal}$, raw; $0.1 \mathrm{Mgal}$, elevated tank, treated; $0.5 \mathrm{Mgal}$, tank, treated.

Service connections 10,000 (September 1975).

Analyses by

U.S. Geological Survey.

\begin{tabular}{|c|c|c|c|}
\hline Constituent & $\begin{array}{l}1972 \\
\text { (raw) }\end{array}$ & $\begin{array}{l}1972 \\
\text { (treated) }\end{array}$ & $\begin{array}{l}1975 \\
\text { (treated) }\end{array}$ \\
\hline Silica $\left(\mathrm{SiO}_{2}\right)$ & -- & -- & 14 \\
\hline Calcium $(\mathrm{Ca})^{\prime}$ & 105 & 48 & 110 \\
\hline Magnesium（Mg） - & -- & -- & 14 \\
\hline Sodium (Na) - & -- & -- & 60 \\
\hline Potassium (K) - & -- & -- & 1 \\
\hline Strontium (Sr) - & -- & -- & .9 \\
\hline Bicarbonate $\left(\mathrm{HCO}_{3}\right)$ & 283 & 100 & 296 \\
\hline Sulfate $\left(\mathrm{SO}_{1}\right)$ & 15 & 18 & 14 \\
\hline Chloride (CI) & 110 & 130 & 130 \\
\hline Fluoride (F) - & .6 & .2 & .4 \\
\hline Nitrate $\left(\mathrm{NO}_{3}-\mathrm{N}\right)$ & -- & -- & .01 \\
\hline Nitrite $\left(\mathrm{NO}_{2}^{3}-\mathrm{N}\right)$ & -- & - & .01 \\
\hline Nitrogen, organic (N) _- & -- & -- & .66 \\
\hline Nitrogen $(\mathrm{NH},-\mathrm{N})$ & -- & -- & .61 \\
\hline Iron $(\mathrm{Fe})$ & -- & -- & .18 \\
\hline Phosphorus (P) - & 1.2 & 0.0 & .27 \\
\hline Dissolved solids (at $180^{\circ} \mathrm{C}$ ) & -1 & -- & 546 \\
\hline Total hardness (as $\mathrm{CaCO}_{3}$ ) - & 310 & 180 & 330 \\
\hline Noncarbonate hardness (as $\mathrm{CaCO}_{3}$ ) - - & -- & -- & 87 \\
\hline Alkalinity (as $\mathrm{CaCO}_{3}$ ) & -- & -- & 243 \\
\hline $\begin{array}{l}\mathrm{pH} \text { (units) } \\
\text { Specific conductance }(\mu \mathrm{mho} / \mathrm{cm} \text { at }\end{array}$ & 8.2 & 8.0 & 7.8 \\
\hline $\left.25^{\circ} \mathrm{C}\right)$ & 800 & 600 & 902 \\
\hline Color (Pt-CO units) & - & -- & 55 \\
\hline Turbidity (JTU) - & -+ & -- & 2 \\
\hline Carbon, organic, total (C) - & -- & -- & 11 \\
\hline Orthophosphate, total $\left(\mathrm{PO}_{4}-\mathrm{P}\right)$ & - & -- & .27 \\
\hline
\end{tabular}


Table 7.--Analyses of raw and treated water from selected water-treatment plants in the Venice-Englewood area--Continued

Location (fig. 1)

Rotunda West.

Supp1y source

8 wells.

Treatment

Reverse-osmosis (RO), $0.5 \mathrm{Mgal} / \mathrm{d}$; aeration, softening, filtration, chlorination, 0.288 $\mathrm{Mgal} / \mathrm{d}$.

Plant capacity - $0.788 \mathrm{Mgal} / \mathrm{d}$.

Storage capacity and type -..- $0.175 \mathrm{Mgal}$, treated.

Service connections - 700 (1977).

Analyses by _- 1971, Physicians Medical Laboratory; 1972, Permutit Co.

\begin{tabular}{|c|c|c|}
\hline Constituent & $\begin{array}{l}1971 \\
\text { (raw) }\end{array}$ & $\begin{array}{c}1972 \\
\text { (treated) }\end{array}$ \\
\hline $\begin{array}{l}\text { Dissolved solids } \\
\left.\text { Total hardness (as } \mathrm{CaCO}_{3}\right) \\
\left.\text { Alkalinity (as } \mathrm{CaCO}_{3}\right) \\
\left.\text { Noncarbonate hardness (as } \mathrm{CaCO}_{3}\right) \\
\text { Bicarbonate }\left(\mathrm{HCO}_{3}\right)\end{array}$ & $\begin{array}{r}6,490 \\
1,650 \\
150 \\
1,500 \\
183\end{array}$ & $\begin{array}{l}25 \\
37 \\
-- \\
-- \\
--\end{array}$ \\
\hline $\begin{array}{l}\text { Iron (Fe) } \\
\text { Sulfate }\left(\mathrm{SO}_{4}\right) \\
\text { Chloride }(\mathrm{CI}) \\
\text { Calcium (Ca) } \\
\text { Magnesium (Mg) }\end{array}$ & $\begin{array}{l}0.05 \\
440 \\
3,435 \\
252 \\
248\end{array}$ & $\begin{array}{r}10 \\
198 \\
4 \\
4\end{array}$ \\
\hline $\begin{array}{l}\text { F1uoride (F) } \\
\text { Carbon dioxide }\left(\mathrm{CO}_{2}\right) \\
\text { Bicarbonate (as } \mathrm{CaCO}_{3} \text { ) } \\
\left.\text { Carbonate (as } \mathrm{CaCO}_{3}\right)^{3} \\
\left.\text { Hydroxide (as } \mathrm{CaCO}_{3}\right)\end{array}$ & $\begin{array}{c}0.42 \\
25 \\
150 \\
0 \\
0\end{array}$ & $\begin{array}{l}-- \\
8 \\
-- \\
--\end{array}$ \\
\hline $\begin{array}{l}\text { Color (Pt-Co units) } \\
\mathrm{pH}, \text { laboratory (units) } \\
\mathrm{pH} \text {, site (units) }\end{array}$ & $\begin{array}{l}5 \\
7.4 \\
7.0\end{array}$ & $\begin{array}{l}0 \\
6.9 \\
--\end{array}$ \\
\hline
\end{tabular}


Table 7.--Analyses of raw and treated water from selected water-treatment plants in the Venice-Englewood area--Continued

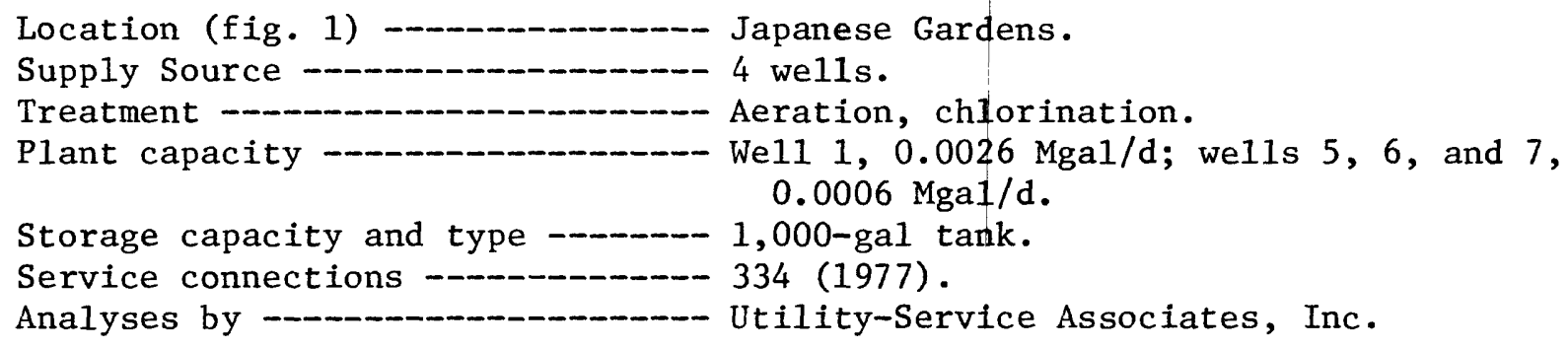

\begin{tabular}{|c|c|c|}
\hline Constituent & $\begin{array}{c}1971 \\
\text { (treated) }\end{array}$ & $\begin{array}{c}1975 \\
\text { (treated) }\end{array}$ \\
\hline Dissolved solids & 500 & 690 \\
\hline Total hardness (as $\mathrm{CaCO}_{3}$ ) - & 352 & 399 \\
\hline Noncarbonate hardness (as $\mathrm{CaCO}_{3}$ ) - - & 42 & 44 \\
\hline Alkalinity (as $\mathrm{CaCO}_{3}$ ) _ & 310 & 355 \\
\hline Bicarbonate $\left(\mathrm{HCO}_{3}\right)$ & 378 & 433 \\
\hline Calcium (Ca) & 168 & 377 \\
\hline Iron $(\mathrm{Fe})$ & 0.20 & 0.06 \\
\hline Sulfate $\left(\mathrm{SO}_{4}\right)$ & 3 & 12 \\
\hline Magnesium (Mg) & 184 & 22 \\
\hline Chloride (C1) & 186 & 146 \\
\hline F1uoride (F) & 0.16 & 0.69 \\
\hline Carbon dioxide $\left(\mathrm{CO}_{2}\right)$ & 60 & 57 \\
\hline Bicarbonate (as $\mathrm{CaCO}_{3}$ ) & 300 & 352 \\
\hline Hydroxide (as $\left.\mathrm{CaCO}_{3}\right)^{3}$ & 0 & 0 \\
\hline Color (Pt-Co units) - & 30 & 90 \\
\hline Odor - & -- & $\begin{array}{c}\text { Chlorine, } \\
\text { slight }\end{array}$ \\
\hline pH, laboratory (units) & 7.1 & 7.1 \\
\hline pH, site (units) & 7.0 & 6.6 \\
\hline
\end{tabular}


Table 7.--Analyses of raw and treated water from selected water-treatment plants in the Venice-Englewood area--Continued

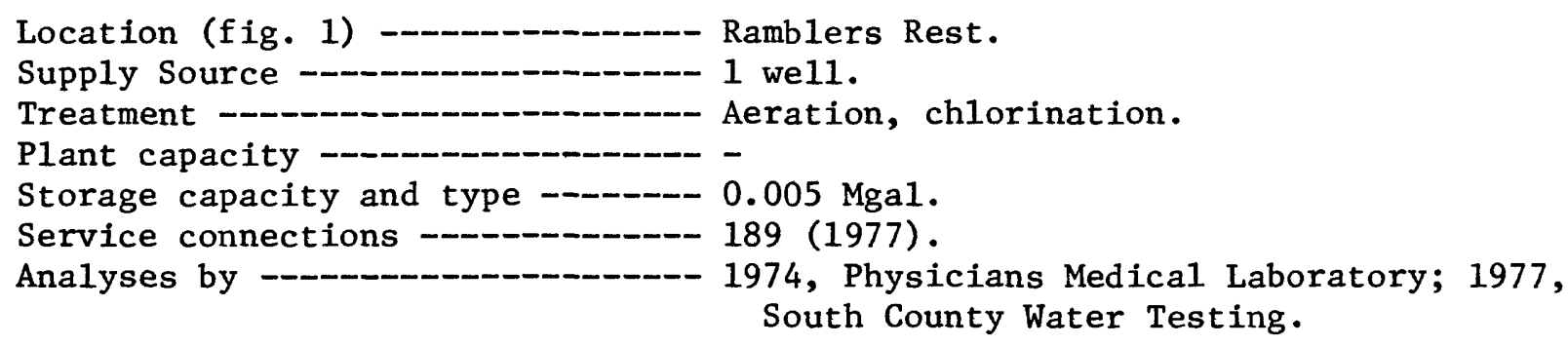

\begin{tabular}{|c|c|c|}
\hline Constituent & $\begin{array}{c}1974 \\
\text { (treated) }\end{array}$ & $\begin{array}{c}1977 \\
\text { (treated) }\end{array}$ \\
\hline Dissolved solids - & 630 & 735 \\
\hline Total hardness (as $\mathrm{CaCO}_{2}$ ) - & 410 & 360 \\
\hline Noncarbonate hardness (ás $\mathrm{CaCO}_{3}$ ) - & 90 & -- \\
\hline Alkalinity (as $\mathrm{CaCO}_{3}$ ) & 320 & 288 \\
\hline Bicarbonate $\left(\mathrm{HCO}_{3}\right)$ & 390 & 351 \\
\hline Iron (Fe) - & 0 & 0.01 \\
\hline Sulfate $\left(\mathrm{SO}_{1}\right)$ & 145 & 88 \\
\hline Chloride (CI) - & 81 & 100 \\
\hline Calcium ( $\mathrm{Ca}$ ) & 100 & 91 \\
\hline Magnesium (Mg) - & 38 & 33 \\
\hline Fluoride (F) - & 1.2 & 1.8 \\
\hline Carbon dioxide $\left(\mathrm{CO}_{2}\right)$ & 30 & 110 \\
\hline Bicarbonate (as $\mathrm{CaCO}_{3}$ ) & 320 & 288 \\
\hline Carbonate (as $\left.\mathrm{CaCO}_{3}\right)^{3}$ & 0 & 0 \\
\hline Hydroxide (as $\mathrm{CaCO}_{3}^{3}$ ) & 0 & 0 \\
\hline Color (Pt-Co units) & 5 & 0 \\
\hline Odor - & 0 & 0 \\
\hline $\mathrm{pH}$, laboratory (units) - & 7.3 & 6.7 \\
\hline $\mathrm{pH}$, site (units) & 7.1 & -- \\
\hline
\end{tabular}


Table 7.--Analyses of raw and treated water from selected water-treatment plants in the Venice-Englewood area--Continued

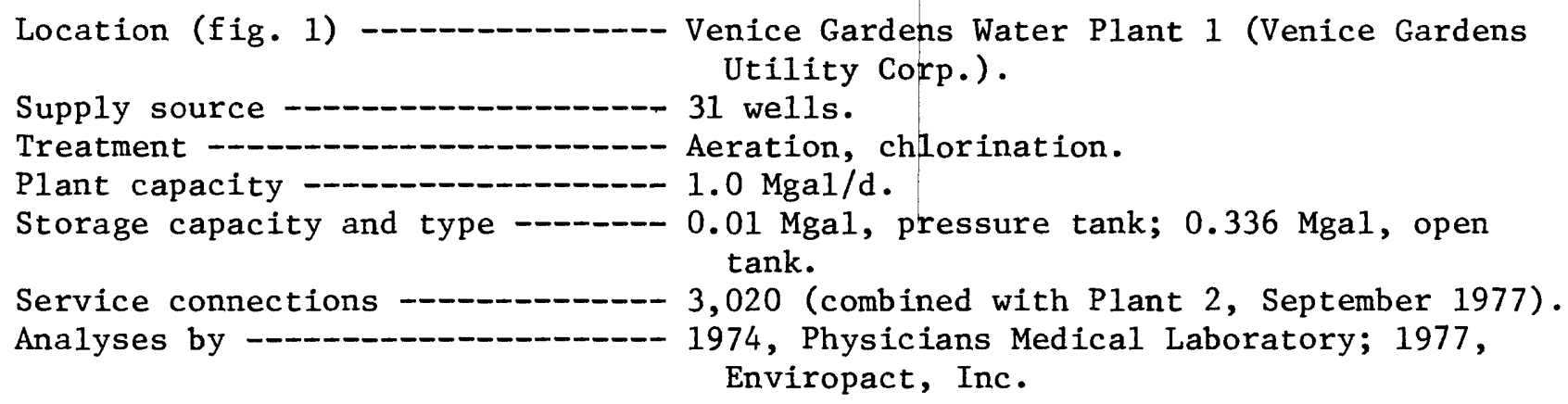

\begin{tabular}{|c|c|c|}
\hline Constituent & $\begin{array}{c}1974 \\
\text { (treated) }\end{array}$ & $\begin{array}{c}1977 \\
\text { (treated) }\end{array}$ \\
\hline Dissolved solids & 490 & 571 \\
\hline Total hardness (as $\mathrm{CaCO}_{3}$ ) & 300 & 340 \\
\hline Alkalinity (as $\mathrm{CaCO}_{2}$ ) & 300 & 272 \\
\hline Noncarbonate hardness (as $\mathrm{CaCO}_{3}$ ) ---- & 0 & 68 \\
\hline Bicarbonate $\left(\mathrm{HCO}_{3}\right)$ & 366 & 332 \\
\hline Calcium (Ca) & 52 & 116 \\
\hline Iron $(\mathrm{Fe})$ & 0.20 & 0.30 \\
\hline Sulfate $\left(\mathrm{SO}_{4}\right)$ & 26 & 31 \\
\hline Magnesium ( $\mathrm{Mg}$ ) & 41 & 8.5 \\
\hline Chloride (C1) & 99 & 102 \\
\hline Fluoride (F) - & 0.10 & 0.42 \\
\hline Carbon dioxide $\left(\mathrm{CO}_{2}\right)$ & 22 & 27 \\
\hline Bicarbonate (as $\mathrm{CaCO}_{3}$ ) & 300 & 272 \\
\hline Hydroxide (as $\left.\mathrm{CaCO}_{3}\right)^{3}$ & 0 & 0 \\
\hline Color (Pt-Co units) & 0 & 20 \\
\hline Odor & 0 & 1 \\
\hline $\mathrm{pH}$, laboratory (units) & 7.4 & 7.3 \\
\hline $\mathrm{pH}$, site (units) & 7.4 & 7.1 \\
\hline
\end{tabular}


Table 7.--Analyses of raw and treated water from selected water-treatment plants in the Venice-Englewood area--Continued

Location (fig. 1) -_____-_ Venice Gardens Water Plant 2 (Venice Gardens Utility Corp.).

Supply source - 39 wells.

Treatment -

Plant capacity - $1.0 \mathrm{Mgal} / \mathrm{d}$.

Storage capacity and type - - $0.01 \mathrm{Mgal}$, pressure tank; $1.36 \mathrm{Mgal}$, open tank.

Service connections Analyses by - 1974, Physicians Medical Laboratory; 1977, Enviropact, Inc.

\begin{tabular}{|c|c|c|}
\hline Constituent & $\begin{array}{c}1974 \\
\text { (treated) }\end{array}$ & $\begin{array}{c}1977 \\
\text { (treated) }\end{array}$ \\
\hline $\begin{array}{l}\text { Dissolved solids } \\
\left.\text { Total hardness (as } \mathrm{CaCO}_{3}\right) \\
\left.\text { Alkalinity (as } \mathrm{CaCO}_{3}\right) \\
\left.\text { Noncarbonate hardness (as } \mathrm{CaCO}_{3}\right) \\
\text { Bicarbonate }\left(\mathrm{HCO}_{3}\right)\end{array}$ & $\begin{array}{r}427 \\
250 \\
220 \\
30 \\
269\end{array}$ & $\begin{array}{r}479 \\
288 \\
236 \\
52 \\
288\end{array}$ \\
\hline $\begin{array}{l}\text { Calcium (Ca) } \\
\text { Iron (Fe) } \\
\left.\text { Sulfate ( } \mathrm{SO}_{4}\right) \\
\text { Magnesium (Mg) } \\
\text { Chloride (C1) }\end{array}$ & $\begin{array}{l}60 \\
0.30 \\
30 \\
24 \\
60\end{array}$ & $\begin{array}{l}97 \\
0.12 \\
30 \\
7.8 \\
80\end{array}$ \\
\hline $\begin{array}{l}\text { Fluoride (F) } \\
\text { Carbon dioxide }\left(\mathrm{CO}_{2}\right) \\
\text { Bicarbonate (as } \mathrm{CaCO}_{3} \text { ) } \\
\left.\text { Hydroxide (as } \mathrm{CaCO}_{3}\right)^{3} \\
\text { Color (Pt-Co units) }\end{array}$ & $\begin{array}{l}0.40 \\
3 \\
220 \\
0 \\
0\end{array}$ & $\begin{array}{l}0.47 \\
22 \\
236 \\
0 \\
0\end{array}$ \\
\hline $\begin{array}{l}\text { Odor } \\
\text { pH, laboratory (units) } \\
\text { pH, site (units) }\end{array}$ & $\begin{array}{l}0 \\
8.1 \\
7.6\end{array}$ & $\begin{array}{l}1 \\
7.3 \\
7.2\end{array}$ \\
\hline
\end{tabular}


Table 7.--Analyses of raw and treated water from selected water-treatment plants in the Venice-Englewood area--Continued

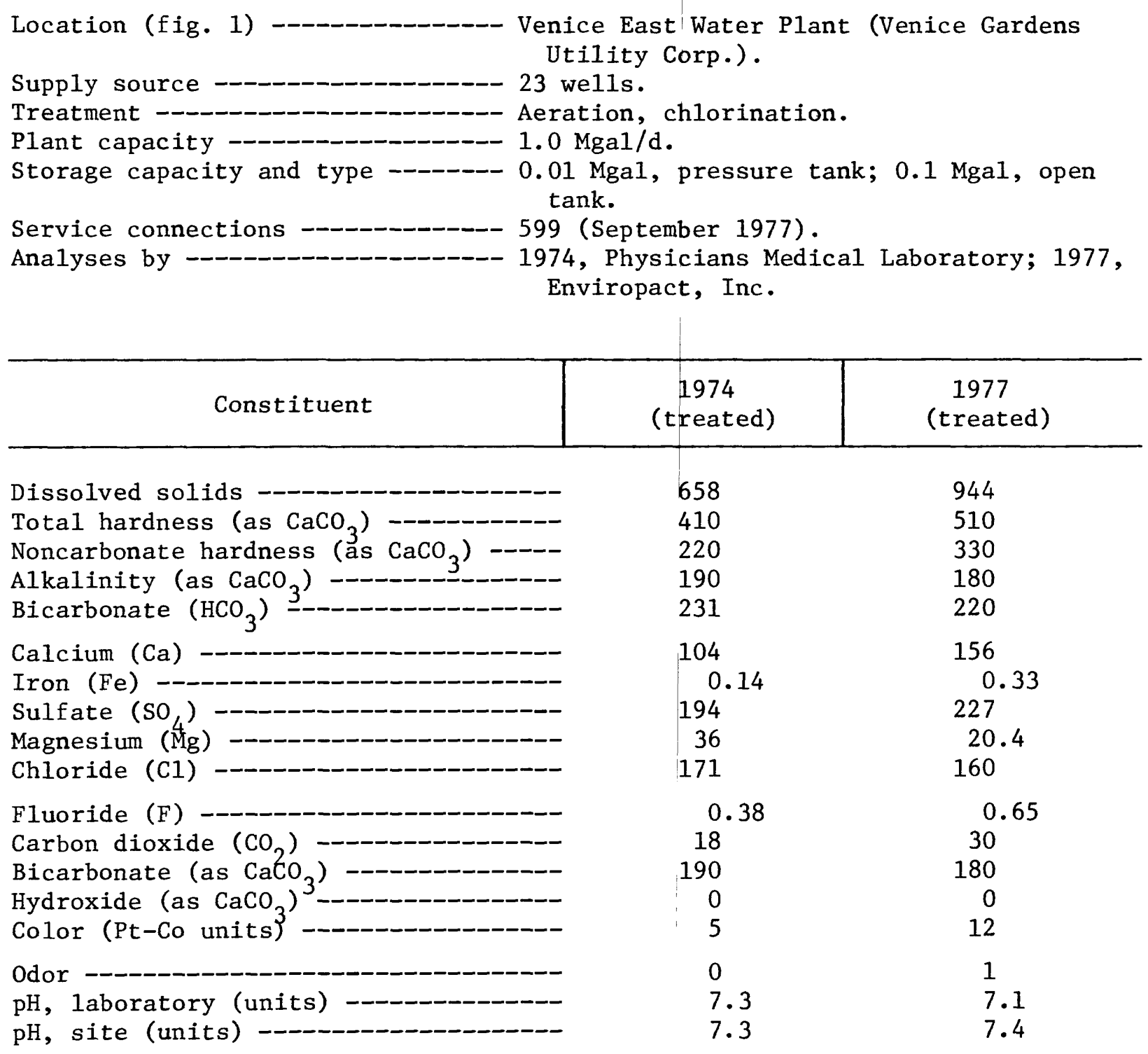


Table 7.--Analyses of raw and treated water from selected water-treatment plants in the Venice-Englewood area--Continued

Location (fig. 1) - _._._. Venice Campgrounds.

Supply source -

Treatment -

Plant capacity - -

Storage capacity and type -.-- $0.0075 \mathrm{Mgal}$.

Service connections - 102 (1977).

Analyses by

1971, Physicians Medical Laboratory; 1977, South County Water Testing.

\begin{tabular}{|c|c|c|}
\hline Constituent & $\begin{array}{c}1971 \\
\text { (treated) }\end{array}$ & $\begin{array}{c}1977 \\
\text { (treated) }\end{array}$ \\
\hline $\begin{array}{l}\text { Dissolved solids } \\
\left.\text { Total hardness (as } \mathrm{CaCO}_{3}\right) \\
\text { Noncarbonate hardness }\left(\mathrm{as} \mathrm{CaCO}_{3}\right) \\
\text { Alaklinity }\left(\mathrm{as} \mathrm{CaCO}_{3}\right) \\
\text { Bicarbonate }\left(\mathrm{HCO}_{3}\right)\end{array}$ & $\begin{array}{l}700 \\
460 \\
230 \\
230 \\
257\end{array}$ & $\begin{array}{r}859 \\
516 \\
-\overline{2} \\
224 \\
273\end{array}$ \\
\hline $\begin{array}{l}\text { Iron (Fe) } \\
\text { Sulfate }\left(\mathrm{SO}_{4}\right) \\
\text { Chloride }(\mathrm{Cl}) \\
\text { Calcium }(\mathrm{Ca}) \\
\text { Magnesium }(\mathrm{Mg})\end{array}$ & $\begin{array}{l}0.04 \\
264 \\
60 \\
108 \\
46\end{array}$ & $\begin{array}{l}0.01 \\
285 \\
74 \\
131 \\
48\end{array}$ \\
\hline $\begin{array}{l}\text { Fluoride (F) } \\
\text { Carbon dioxide }\left(\mathrm{CO}_{2}\right) \\
\left.\text { Bicarbonate (as } \mathrm{CaCO}_{3}\right) \\
\left.\text { Carbonate (as } \mathrm{CaCO}{ }_{3}\right)^{3} \\
\left.\text { Hydroxide (as } \mathrm{CaCO}_{3}\right)\end{array}$ & $\begin{array}{l}0.92 \\
28 \\
230 \\
0 \\
0\end{array}$ & $\begin{array}{l}0.96 \\
44 \\
224 \\
0 \\
0\end{array}$ \\
\hline $\begin{array}{l}\text { Color (Pt-Co units) } \\
\mathrm{pH}, \text { laboratory (units) } \\
\mathrm{pH} \text {, site (units) }\end{array}$ & $\begin{array}{l}5 \\
7.2 \\
7.2\end{array}$ & $\begin{array}{l}0 \\
7.0 \\
--\end{array}$ \\
\hline
\end{tabular}


Table 7.--Analyses of raw and treated water from selected water-treatment plants in the Venice-Englewood area--Continued

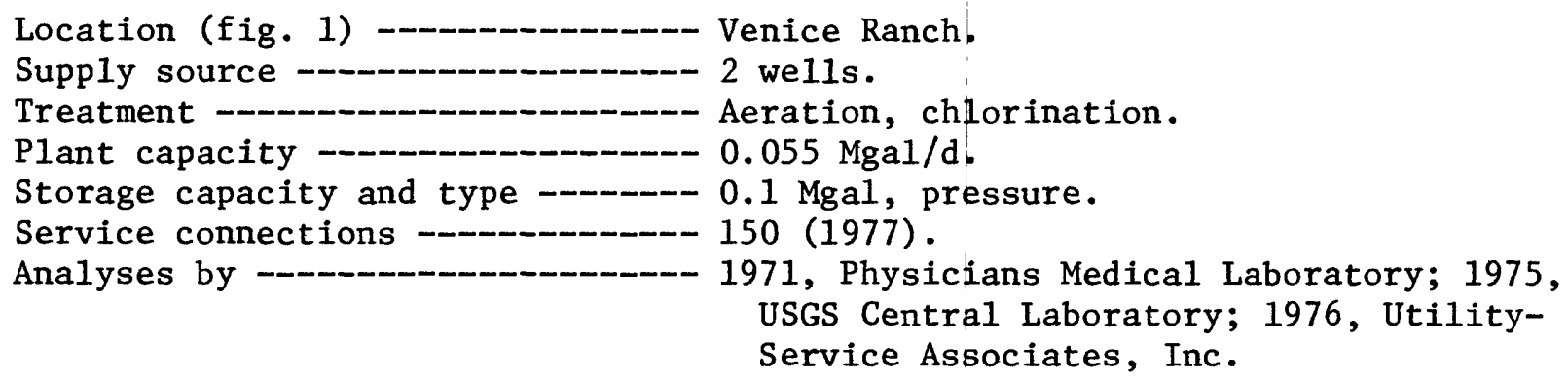

\begin{tabular}{|c|c|c|c|}
\hline Constituent & $\begin{array}{l}1971 \\
\text { (raw) }\end{array}$ & $\begin{array}{l}1975 \\
\text { (raw) }\end{array}$ & $\begin{array}{c}1976 \\
\text { (treated) }\end{array}$ \\
\hline $\begin{array}{l}\text { Dissolved solids } \\
\left.\text { Total hardness (as } \mathrm{CaCO}_{3}\right) \\
\text { Noncarbonate hardness }\left(\mathrm{as} \mathrm{CaCO}_{3}\right) \\
\text { Alkalinity }\left(\text { as } \mathrm{CaCO}_{3}\right) \\
\text { Bicarbonate }\left(\mathrm{HCO}_{3}\right)\end{array}$ & $\begin{array}{r}1,120 \\
340 \\
180 \\
160 \\
195\end{array}$ & $\begin{array}{r}1,440 \\
550 \\
350 \\
-- \\
251\end{array}$ & $\begin{array}{r}1,326 \\
682 \\
522 \\
160 \\
195\end{array}$ \\
\hline $\begin{array}{l}\text { Calcium (Ca) } \\
\text { Iron (Fe) } \\
\left.\text { Sulfate ( } \mathrm{SO}_{4}\right) \\
\text { Magnesium (Mg) } \\
\text { Chloride (CI) }\end{array}$ & $\begin{array}{r}92 \\
0 \\
178 \\
25 \\
126\end{array}$ & $\begin{array}{r}140 \\
-- \\
260 \\
49 \\
160\end{array}$ & $\begin{array}{l}184 \\
0.08 \\
435 \\
54 \\
331\end{array}$ \\
\hline $\begin{array}{l}\text { Fluoride (F) } \\
\text { Carbon dioxide }\left(\mathrm{CO}_{2}\right) \\
\left.\text { Bicarbonate (as } \mathrm{CaCO}_{3}\right) \\
\left.\text { Hydroxide (as } \mathrm{CaCO}_{3}\right)^{3} \\
\text { Color (Pt-Co units) }\end{array}$ & $\begin{array}{c}0.6 \\
15 \\
160 \\
0 \\
5\end{array}$ & $\begin{array}{c}0.2 \\
-- \\
251 \\
-- \\
--\end{array}$ & $\begin{array}{c}0.76 \\
13 \\
156 \\
0 \\
15\end{array}$ \\
\hline $\begin{array}{l}\text { Odor } \\
\text { pH, laboratory (units) } \\
\text { pH, site (units) }\end{array}$ & $\begin{array}{l}0 \\
7.3 \\
7.4\end{array}$ & -- & $\begin{array}{c}\text { chlorine } \\
7.4 \\
7.1\end{array}$ \\
\hline
\end{tabular}


Táble 8.--Records of wells that supply water-treatment plants, Venice-Englewood area

[Aquifers: SA, surficial aquifer, 1, zone 1; 2, zone 2; 3, zone 3]

\begin{tabular}{c|c|c|c|c|c|c}
\hline $\begin{array}{c}\text { Location } \\
\text { number }\end{array}$ & $\begin{array}{c}\text { We11 } \\
\text { number }\end{array}$ & $\begin{array}{l}\text { Depth } \\
(\mathrm{ft})\end{array}$ & $\begin{array}{l}\text { Diam- } \\
\text { eter } \\
(\mathrm{in})\end{array}$ & $\begin{array}{l}\text { Casing } \\
\text { depth } \\
(\mathrm{ft})\end{array}$ & $\begin{array}{l}\text { Aquifer } \\
\text { or zone }\end{array}$ & Remarks \\
\hline
\end{tabular}

City of Venice

Production wells

$\begin{array}{llrlcc}270534082260201 & 1 & 66 & 4 & 41 & 1 \\ 270537082260201 & 1 \mathrm{~N} & 92 & 4 & 39 & 1,2 \\ 270534082260201 & 2 & 67 & 4 & 46 & 1 \\ 270539082260401 & 2 \mathrm{~N} & 100 & 4 & 39 & 1,2 \\ 270541082260601 & 3 \mathrm{~S} & 47 & 2 & 31 & 1 \\ 270548082260801 & 4 \mathrm{~S} & 125 & 2 & 32 & 1,2 \\ 270538082254801 & 5 & 114 & 4 & 32 & 1,2 \\ 270538082254601 & 6 & 112 & 4 & 33 & 1,2 \\ 270555082261101 & 7 \mathrm{~S} & 105 & 4 & 30 & 1,2 \\ 270538082254301 & 7 \mathrm{~N} & 105 & 2 & 29 & 1,2 \\ 270557082261401 & 9 \mathrm{~S} & 110 & 4 & 29 & 1,2 \\ 270553082263701 & 10 & 113 & 6 & 32 & 1,2 \\ 270553082261801 & 11 \mathrm{~S} & 134 & 4 & 34 & 1,2 \\ 270553082261701 & 12 \mathrm{~N} & 96 & 2 & 28 & 1,2 \\ 270550082261001 & 13 \mathrm{~N} & 108 & 2 & 33 & 1,2 \\ 270545082261201 & 14 \mathrm{~S} & 124 & 4 & 32 & 1,2 \\ 270538082260701 & 15 & 98 & 4 & 34 & 1,2 \\ 270543082260801 & 15 \mathrm{E} & 105 & 4 & 40 & 1,2 \\ 270543082260901 & 16 & 111 & 4 & 45 & 1,2 \\ 270533082260201 & 17 & 114 & 4 & 48 & 1,2 \\ 270538082260701 & 18 & 140 & 4 & 46 & 1,2 \\ 270538082260301 & 21 & 144 & 4 & 84 & 1,2 \\ 270538082260001 & 22 & 125 & 4 & 52 & 1,2 \\ 270538082255701 & 23 & 120 & 4 & 104 & 2 \\ 270538082255301 & 24 & 120 & 4 & 52.5 & 1,2 \\ 270538082255001 & 25 & 185 & 4 & 120 & 2 \\ 270538082254801 & 26 & 118 & 4 & 83 & 2 \\ 270538082254601 & 27 & 118 & 4 & 54 & 1,2 \\ 270538082254301 & 28 & 60 & 4 & 40 & 1 \\ 270538082254201 & 29 & 65 & 4 & 40 & 1 \\ 270538082254001 & 30 & 110 & 4 & 42 & 1,2 \\ 270538082253701 & 31 & 59 & 4 & 42 & 1 \\ 270538082253501 & 32 & 59 & 4 & 42 & 1 \\ 270558082253701 & 33 & 131 & 6 & 39 & 1,2 \\ 270558082253201 & 34 & 99 & 6 & 39 & 1,2 \\ 270558082252501 & 35 & 128 & 6 & 78 & 2 \\ 270558082251801 & 36 & 51 & 6 & 34 & 1 \\ 270557082257201 & 37 & 130 & 6 & 80 & 2 \\ 270557082253001 & 38 & 99 & 6 & 41 & 1,2 \\ 270603082250301 & 39 & 46 & 6 & 36 & 1\end{array}$


Table 8.--Records of wells that supply water-treatment plants, Venice-Englewood area--Continued

\begin{tabular}{|c|c|c|c|c|c|c|}
\hline $\begin{array}{l}\text { Location } \\
\text { number }\end{array}$ & $\begin{array}{l}\text { Well } \\
\text { number }\end{array}$ & $\begin{array}{l}\text { Depth } \\
(f t)\end{array}$ & $\begin{array}{l}\text { Diam- } \\
\text { eter } \\
\text { (in) }\end{array}$ & $\begin{array}{l}\text { Casing } \\
\text { depth } \\
\text { (ft) }\end{array}$ & $\begin{array}{l}\text { Aquifer } \\
\text { or zone }\end{array}$ & Remarks \\
\hline \multicolumn{7}{|c|}{ City of Venice } \\
\hline \multicolumn{7}{|c|}{ Production wells--continued } \\
\hline $\begin{array}{l}270508082250301 \\
270613082250301 \\
270603082245801 \\
270608082245801 \\
270603082245301\end{array}$ & $\begin{array}{l}40 \\
41 \\
42 \\
43 \\
44\end{array}$ & $\begin{array}{l}128 \\
130 \\
130 \\
130 \\
150\end{array}$ & $\begin{array}{l}6 \\
6 \\
6 \\
6 \\
6\end{array}$ & $\begin{array}{l}79 \\
74 \\
81 \\
52 \\
35\end{array}$ & $\begin{array}{c}2 \\
2 \\
2 \\
1,2 \\
1,2\end{array}$ & \\
\hline $\begin{array}{l}270608082245301 \\
270603082244901 \\
270608082244901 \\
270613082245801 \\
270618082250301\end{array}$ & $\begin{array}{l}45 \\
46 \\
47 \\
48 \\
49\end{array}$ & $\begin{array}{l}150 \\
150 \\
150 \\
150 \\
100\end{array}$ & $\begin{array}{l}6 \\
6 \\
6 \\
6 \\
6\end{array}$ & $\begin{array}{l}35 \\
25 \\
33 \\
42 \\
70\end{array}$ & $\begin{array}{c}1,2 \\
1,2 \\
1,2 \\
1,2 \\
2\end{array}$ & \\
\hline $\begin{array}{l}270604082261601 \\
270613082245001\end{array}$ & $\begin{array}{l}51 \\
52\end{array}$ & $\begin{array}{l}130 \\
127\end{array}$ & $\begin{array}{l}6 \\
6\end{array}$ & $\begin{array}{l}42 \\
42\end{array}$ & $\begin{array}{l}1,2 \\
1,2\end{array}$ & $\begin{array}{l}\text { Used to irrigate ball } \\
\text { field }\end{array}$ \\
\hline $\begin{array}{l}270557082245801 \\
270557082245401 \\
270557082245001\end{array}$ & $\begin{array}{l}57 \\
58 \\
59\end{array}$ & $\begin{array}{l}150 \\
190 \\
150\end{array}$ & $\begin{array}{l}6 \\
6 \\
6\end{array}$ & $\begin{array}{l}49 \\
83 \\
82\end{array}$ & $\begin{array}{c}1,2 \\
2 \\
2\end{array}$ & \\
\hline $\begin{array}{l}270557082244601 \\
270557082244201 \\
270557082243701 \\
270557082243301 \\
270557082242801\end{array}$ & $\begin{array}{l}60 \\
61 \\
62 \\
63 \\
64\end{array}$ & $\begin{array}{l}130 \\
150 \\
150 \\
150 \\
150\end{array}$ & $\begin{array}{l}6 \\
6 \\
6 \\
6\end{array}$ & $\begin{array}{l}79 \\
88 \\
73 \\
72\end{array}$ & $\begin{array}{l}2 \\
2 \\
2 \\
2\end{array}$ & \\
\hline $\begin{array}{l}270557082242301 \\
270557082241801 \\
270557082241401 \\
270557082241001 \\
270557082240601\end{array}$ & $\begin{array}{l}65 \\
66 \\
67 \\
68 \\
69\end{array}$ & $\begin{array}{l}150 \\
130 \\
150 \\
110 \\
110\end{array}$ & $\begin{array}{l}6 \\
6 \\
6 \\
6 \\
6\end{array}$ & $\begin{array}{l}76 \\
72 \\
65 \\
76 \\
84\end{array}$ & $\begin{array}{l}2 \\
2 \\
2 \\
2 \\
2\end{array}$ & \\
\hline \multicolumn{7}{|c|}{ Production wells, reverse-osmosis } \\
\hline $\begin{array}{l}270601082261801 \\
270607082262801 \\
270556082262401 \\
270544082261801 \\
270533082261001\end{array}$ & $\begin{array}{l}\text { R01 } \\
\text { R02 } \\
\text { R03 } \\
\text { R04 } \\
\text { R05 }\end{array}$ & $\begin{array}{l}260 \\
250 \\
265 \\
405 \\
650\end{array}$ & $\begin{array}{l}8 \\
8 \\
8 \\
8 \\
8\end{array}$ & $\begin{array}{l}205 \\
203 \\
207 \\
204 \\
202\end{array}$ & $\begin{array}{c}2 \\
2 \\
2,3 \\
2,3 \\
2,3\end{array}$ & \\
\hline \multicolumn{7}{|c|}{ Observation we11s } \\
\hline $\begin{array}{l}270542082261801 \\
270543082261902 \\
270542082261701 \\
270540082261701 \\
270542082261601\end{array}$ & $\begin{array}{l}35 \\
36 \\
37 \\
38 \\
39\end{array}$ & $\begin{array}{r}163 \\
68 \\
45 \\
47 \\
27\end{array}$ & $\begin{array}{l}6 \\
6 \\
6 \\
2 \\
2\end{array}$ & $\begin{array}{l}86 \\
58 \\
38 \\
31 \\
24\end{array}$ & $\begin{array}{r}2 \\
1 \\
1 \\
1 \\
\mathrm{SA}\end{array}$ & \\
\hline $\begin{array}{l}270543082261701 \\
270540082261801\end{array}$ & $\begin{array}{l}40 \\
41\end{array}$ & $\begin{array}{l}40 \\
27\end{array}$ & $\begin{array}{l}2 \\
2\end{array}$ & $\begin{array}{l}35 \\
24\end{array}$ & $\begin{array}{l}\text { SA } \\
\text { SA }\end{array}$ & \\
\hline
\end{tabular}


Table 8.--Records of wells that supply water-treatment plants, Venice-Englewood area--Continued

\begin{tabular}{|c|c|c|c|c|c|c|}
\hline $\begin{array}{l}\text { Location } \\
\text { number }\end{array}$ & $\begin{array}{c}\text { We11 } \\
\text { number }\end{array}$ & $\begin{array}{l}\text { Depth } \\
(f t)\end{array}$ & $\begin{array}{l}\text { Diam- } \\
\text { eter } \\
\text { (in) }\end{array}$ & $\begin{array}{l}\text { Casing } \\
\text { depth } \\
(\mathrm{ft})\end{array}$ & $\begin{array}{l}\text { Aquifer } \\
\text { or zone }\end{array}$ & Remarks \\
\hline \multicolumn{7}{|c|}{ City of Venice } \\
\hline \multicolumn{7}{|c|}{ Test we11s } \\
\hline $\begin{array}{l}270641082245501 \\
270613082252301 \\
270538082250401 \\
270557082242201\end{array}$ & $\begin{array}{l}\text { TH-1 } \\
\text { TH-2 } \\
\text { TH-3 } \\
\text { TH-4 }\end{array}$ & $\begin{array}{l}205 \\
110 \\
140 \\
150\end{array}$ & $\begin{array}{l}3 \\
3 \\
3 \\
6\end{array}$ & $\begin{array}{l}40 \\
35 \\
36 \\
81\end{array}$ & $\begin{array}{c}1,2 \\
1,2 \\
1,2 \\
2\end{array}$ & \\
\hline \multicolumn{7}{|c|}{ Englewood Water District } \\
\hline \multicolumn{7}{|c|}{ Production wells } \\
\hline $\begin{array}{l}265659082211001 \\
265706082210801 \\
265713082210801 \\
265659082205701 \\
265707082205701\end{array}$ & $\begin{array}{l}1 \mathrm{~A} \\
2 \mathrm{~A} \\
3 \mathrm{~A} \\
4 \mathrm{~A} \\
5 \mathrm{~A}\end{array}$ & $\begin{array}{r}75 \\
75 \\
75 \\
88 \\
100\end{array}$ & $\begin{array}{l}6 \\
6 \\
6 \\
6 \\
6\end{array}$ & $\begin{array}{l}69 \\
60 \\
58 \\
74 \\
68\end{array}$ & $\begin{array}{c}1 \\
1 \\
1 \\
1,2 \\
1,2\end{array}$ & \\
\hline $\begin{array}{l}265713082205701 \\
265736082204301 \\
265736082204301 \\
265736082205101 \\
265735082205601\end{array}$ & $\begin{array}{l}11 \\
12 \\
13 \\
14 \\
15\end{array}$ & $\begin{array}{l}85 \\
40 \\
66 \\
67 \\
65\end{array}$ & $\begin{array}{l}6 \\
6 \\
6 \\
6 \\
6\end{array}$ & $\begin{array}{l}55 \\
20 \\
45 \\
43 \\
44\end{array}$ & $\begin{array}{c}1,2 \\
\text { SA } \\
1 \\
1 \\
1\end{array}$ & \\
\hline $\begin{array}{l}265742082205701 \\
265729082205701 \\
265722082205701 \\
265717082210301 \\
265739082205701\end{array}$ & $\begin{array}{l}16 \\
17 \\
18 \\
19 \\
20\end{array}$ & $\begin{array}{l}72 \\
71 \\
82 \\
82 \\
40\end{array}$ & $\begin{array}{l}6 \\
6 \\
6 \\
6 \\
6\end{array}$ & $\begin{array}{l}49 \\
52 \\
54 \\
56 \\
20\end{array}$ & $\begin{array}{l}1 \\
1 \\
1 \\
1 \\
\text { SA }\end{array}$ & 20 feet of screen \\
\hline $\begin{array}{l}265733082205701 \\
265727082205701 \\
265718082205101 \\
265659082210301 \\
265709082210301\end{array}$ & $\begin{array}{l}21 \\
22 \\
23 \\
24 \\
25\end{array}$ & $\begin{array}{l}40 \\
40 \\
40 \\
40 \\
40\end{array}$ & $\begin{array}{l}6 \\
6 \\
6 \\
6 \\
6\end{array}$ & $\begin{array}{l}20 \\
25 \\
20 \\
20 \\
20\end{array}$ & $\begin{array}{l}\text { SA } \\
\text { SA } \\
\text { SA } \\
\text { SA } \\
\text { SA }\end{array}$ & $\begin{array}{l}\text { Do. } \\
\text { Do. } \\
\text { Do. } \\
\text { Do. } \\
\text { Do. }\end{array}$ \\
\hline $\begin{array}{l}265713082210301 \\
265722082210301 \\
265728082210301 \\
265736082210301 \\
265742082210301\end{array}$ & $\begin{array}{l}26 \\
27 \\
28 \\
29 \\
30\end{array}$ & $\begin{array}{l}40 \\
40 \\
40 \\
40 \\
40\end{array}$ & $\begin{array}{l}6 \\
6 \\
6 \\
6 \\
6\end{array}$ & $\begin{array}{l}20 \\
25 \\
20 \\
20 \\
20\end{array}$ & $\begin{array}{l}\text { SA } \\
\text { SA } \\
\text { SA } \\
\text { SA } \\
\text { SA }\end{array}$ & $\begin{array}{l}\text { Do. } \\
\text { Do. } \\
\text { Do. } \\
\text { Do. } \\
\text { Do. }\end{array}$ \\
\hline $\begin{array}{l}265826082202601 \\
265826082201801 \\
265826082201101 \\
265826082200401 \\
265826082195801\end{array}$ & $\begin{array}{l}31 \\
32 \\
33 \\
34 \\
35\end{array}$ & $\begin{array}{l}60 \\
65 \\
69 \\
85 \\
80\end{array}$ & $\begin{array}{l}6 \\
6 \\
6 \\
6 \\
6\end{array}$ & $\begin{array}{l}46 \\
49 \\
52 \\
52 \\
46\end{array}$ & $\begin{array}{l}1 \\
1 \\
1 \\
1 \\
1\end{array}$ & \\
\hline $\begin{array}{l}265826082195001 \\
265826082194201 \\
265833082202601 \\
265833082201801 \\
265833082201101\end{array}$ & $\begin{array}{l}36 \\
37 \\
38 \\
39 \\
40\end{array}$ & $\begin{array}{l}50 \\
70 \\
60 \\
53 \\
60\end{array}$ & $\begin{array}{l}6 \\
6 \\
6 \\
6 \\
6\end{array}$ & $\begin{array}{l}41 \\
43 \\
43 \\
36 \\
49\end{array}$ & $\begin{array}{l}1 \\
1 \\
1 \\
1 \\
1\end{array}$ & \\
\hline
\end{tabular}


Table 8.--Records of wells that supply water-treatment plants, Venice-Englewood area--Continued

\begin{tabular}{|c|c|c|c|c|c|c|}
\hline $\begin{array}{l}\text { Location } \\
\text { number }\end{array}$ & $\begin{array}{c}\text { We11 } \\
\text { number }\end{array}$ & $\begin{array}{l}\text { Depth } \\
(f t)\end{array}$ & $\begin{array}{l}\text { Diam- } \\
\text { eter } \\
\text { (in) }\end{array}$ & $\begin{array}{l}\text { Casing } \\
\text { depth } \\
\text { (ft) }\end{array}$ & $\begin{array}{l}\text { Aquifer } \\
\text { or zone }\end{array}$ & Remarks \\
\hline \multicolumn{7}{|c|}{ Englewood Water District } \\
\hline \multicolumn{7}{|c|}{ Production wells--continued } \\
\hline $\begin{array}{l}265833082200401 \\
265833082195801 \\
265833082195001 \\
265833082194201 \\
265757082202801\end{array}$ & $\begin{array}{l}41 \\
42 \\
43 \\
44 \\
45\end{array}$ & $\begin{array}{l}50 \\
90 \\
85 \\
60 \\
92\end{array}$ & $\begin{array}{l}6 \\
6 \\
6 \\
6 \\
6\end{array}$ & $\begin{array}{l}37 \\
49 \\
48 \\
52 \\
49\end{array}$ & $\begin{array}{l}1 \\
1 \\
1 \\
1 \\
1\end{array}$ & \\
\hline $\begin{array}{l}265801082202701 \\
265808082202701 \\
265817082202601\end{array}$ & $\begin{array}{l}46 \\
47 \\
48\end{array}$ & $\begin{array}{l}90 \\
90 \\
90\end{array}$ & $\begin{array}{l}6 \\
6 \\
6\end{array}$ & $\begin{array}{l}50 \\
53 \\
42\end{array}$ & $\begin{array}{l}1 \\
1 \\
1\end{array}$ & \\
\hline \multicolumn{7}{|c|}{ Miscellaneous wells } \\
\hline $\begin{array}{l}265712082205702 \\
265926082222401 \\
265712082205701 \\
270021082221301 \\
270018082210901\end{array}$ & $\begin{array}{l}\mathrm{A} 1 \\
1 \mathrm{R} \\
2 \mathrm{R} \\
3 \mathrm{R} \\
4 \mathrm{R}\end{array}$ & $\begin{array}{r}17 \\
90 \\
110 \\
42 \\
80\end{array}$ & $\begin{array}{l}4 \\
3 \\
4 \\
4 \\
4\end{array}$ & $\begin{array}{l}7 \\
55 \\
51 \\
42 \\
35\end{array}$ & $\begin{array}{c}\text { SA } \\
1,2 \\
1,2 \\
1 \\
1,2\end{array}$ & $\begin{array}{l}10 \text { feet of screen } \\
\text { Deep observation well }\end{array}$ \\
\hline $\begin{array}{l}270019082213701 \\
265927082211201 \\
270018082201301 \\
265927082195201 \\
270112082201201\end{array}$ & $\begin{array}{l}5 \mathrm{R} \\
6 \mathrm{R} \\
\mathrm{C} 7 \\
\mathrm{C} 8 \\
\mathrm{C} 9\end{array}$ & $\begin{array}{r}92 \\
112 \\
120 \\
110 \\
120\end{array}$ & $\begin{array}{l}4 \\
4 \\
3 \\
3 \\
3\end{array}$ & $\begin{array}{l}34 \\
73 \\
48 \\
56 \\
65\end{array}$ & $\begin{array}{l}1,2 \\
1,2 \\
1,2 \\
1,2 \\
1,2\end{array}$ & \\
\hline $\begin{array}{l}270036082213401 \\
265808082202501 \\
270036082214101 \\
265653082190301 \\
265710082205101\end{array}$ & $\begin{array}{l}\text { C10 } \\
\text { TW8 } \\
\text { PT1 } \\
\text { R01 } \\
\text { R02 }\end{array}$ & $\begin{array}{r}70 \\
53 \\
60 \\
320 \\
310\end{array}$ & $\begin{array}{l}6 \\
3 \\
6 \\
4 \\
4\end{array}$ & $\begin{array}{r}42 \\
45 \\
35 \\
174 \\
152\end{array}$ & $\begin{array}{c}1 \\
1 \\
1 \\
2,3 \\
2,3\end{array}$ & $\begin{array}{c}\text { McElmurry well } \\
\text { Deep observation well } \\
\text { Do. }\end{array}$ \\
\hline $\begin{array}{l}265809082194001 \\
265834082202401\end{array}$ & $\begin{array}{r}\text { TW6 } \\
\text { TW14 }\end{array}$ & $\begin{array}{l}65 \\
55\end{array}$ & $\begin{array}{l}3 \\
6\end{array}$ & $\begin{array}{l}47 \\
45\end{array}$ & $\begin{array}{l}1 \\
1\end{array}$ & $\begin{array}{c}\text { Observation well } \\
\text { Do. }\end{array}$ \\
\hline \multicolumn{7}{|c|}{ Rotunda West } \\
\hline \multicolumn{7}{|c|}{ Production wells } \\
\hline $\begin{array}{l}265158082171701 \\
265202082171701 \\
265259082174901 \\
265305082174901 \\
265307082174901\end{array}$ & $\begin{array}{r}2 \\
6 \\
21 \\
22 \\
23\end{array}$ & $\begin{array}{r}140 \\
140 \\
30 \\
30 \\
30\end{array}$ & $\begin{array}{l}8 \\
8 \\
3 \\
3 \\
3\end{array}$ & $\begin{array}{l}60 \\
60 \\
30 \\
27 \\
27\end{array}$ & $\begin{array}{l}2 \\
2 \\
\text { SA } \\
\text { SA } \\
\text { SA }\end{array}$ & $\begin{array}{c}\text { Reverse-osmosis well } \\
\text { Do. }\end{array}$ \\
\hline $\begin{array}{l}265309082174901 \\
265304082175001 \\
265308082174801\end{array}$ & $\begin{array}{l}24 \\
25 \\
26\end{array}$ & $\begin{array}{l}27 \\
30 \\
30\end{array}$ & $\begin{array}{l}3 \\
3 \\
3\end{array}$ & $\begin{array}{l}26 \\
27 \\
27\end{array}$ & $\begin{array}{l}\text { SA } \\
\text { SA } \\
\text { SA }\end{array}$ & \\
\hline
\end{tabular}


Table 8.--Records of wells that supply water-treatment plants, Venice-Englewood area--Continued

\begin{tabular}{|c|c|c|c|c|c|c|}
\hline $\begin{array}{l}\text { Location } \\
\text { number }\end{array}$ & $\begin{array}{c}\text { We11 } \\
\text { number }\end{array}$ & $\begin{array}{l}\text { Depth } \\
(f t)\end{array}$ & $\begin{array}{l}\text { Diam- } \\
\text { eter } \\
\text { (in) }\end{array}$ & $\begin{array}{l}\text { Casing } \\
\text { depth } \\
(\mathrm{ft})\end{array}$ & $\begin{array}{l}\text { Aquifer } \\
\text { or zone }\end{array}$ & Remarks \\
\hline \multicolumn{7}{|c|}{ Japanese Gardens } \\
\hline \multicolumn{7}{|c|}{ Production wells } \\
\hline $\begin{array}{l}270137082240701 \\
270114082241101 \\
270122082241101 \\
270139082240901\end{array}$ & $\begin{array}{l}2 \\
5 \\
6 \\
7\end{array}$ & $\begin{array}{r}104 \\
72 \\
93 \\
100\end{array}$ & $\begin{array}{l}4 \\
4 \\
4 \\
4\end{array}$ & $\begin{array}{l}50 \\
63 \\
42 \\
42\end{array}$ & $\begin{array}{c}1,2 \\
1 \\
1 \\
1,2\end{array}$ & \\
\hline \multicolumn{7}{|c|}{ Ramblers Rest } \\
\hline \multicolumn{7}{|c|}{ Production well } \\
\hline 270408082191101 & 1 & 90 & 4 & 43 & 1,2 & \\
\hline \multicolumn{7}{|c|}{ Venice Gardens 1} \\
\hline \multicolumn{7}{|c|}{ Production wells } \\
\hline $\begin{array}{l}270422082244701 \\
270422082244401\end{array}$ & $\begin{array}{l}1 \\
2 \\
3 \\
4 \\
5\end{array}$ & $\begin{array}{r}64 \\
90 \\
130 \\
130 \\
137\end{array}$ & $\begin{array}{l}4 \\
4 \\
4 \\
4 \\
4\end{array}$ & $\begin{array}{r}61 \\
62 \\
110 \\
110\end{array}$ & $\begin{array}{l}1 \\
1 \\
2 \\
2 \\
2\end{array}$ & $\begin{array}{c}\text { Inactive } \\
\text { Do. } \\
\text { Do. } \\
\text { Inactive }\end{array}$ \\
\hline $\begin{array}{l}270430082231701 \\
270428082231701 \\
270426082231701 \\
270430082231001\end{array}$ & $\begin{array}{r}6 \\
7 \\
8 \\
9 \\
10\end{array}$ & $\begin{array}{l}141 \\
143 \\
145\end{array}$ & $\begin{array}{l}4 \\
4 \\
4 \\
4 \\
4\end{array}$ & & $\begin{array}{l}2 \\
2 \\
- \\
- \\
2\end{array}$ & $\begin{array}{l}\text { Do. } \\
\text { Do. } \\
\text { Do. } \\
\text { Do. } \\
\text { Do. }\end{array}$ \\
\hline $\begin{array}{l}270428082231001 \\
270426082231001 \\
270417082244701 \\
270422082231001 \\
270418082244601\end{array}$ & $\begin{array}{l}11 \\
12 \\
13 \\
14 \\
15\end{array}$ & $\begin{array}{l}152 \\
166 \\
136 \\
102\end{array}$ & $\begin{array}{l}4 \\
4 \\
4 \\
4 \\
4\end{array}$ & & $\begin{array}{l}- \\
2 \\
2 \\
2 \\
2\end{array}$ & $\begin{array}{c}\text { Do. } \\
\text { Do. } \\
\text { Do. } \\
\text { Inactive }\end{array}$ \\
\hline \multirow[t]{3}{*}{270417082244801} & $\begin{array}{l}16 \\
17 \\
18 \\
19 \\
20\end{array}$ & $\begin{array}{l}137 \\
146.5 \\
149 \\
144 \\
143\end{array}$ & $\begin{array}{l}4 \\
4 \\
4 \\
4 \\
4\end{array}$ & $\begin{array}{l}64 \\
63\end{array}$ & $\begin{array}{c}2 \\
2 \\
2 \\
1,2 \\
1,2\end{array}$ & Inactive \\
\hline & $\begin{array}{l}21 \\
22 \\
23 \\
24 \\
25\end{array}$ & $\begin{array}{l}142 \\
145 \\
139.5 \\
145 \\
141\end{array}$ & $\begin{array}{l}4 \\
4 \\
4 \\
4 \\
4\end{array}$ & $\begin{array}{l}63 \\
63 \\
63 \\
63\end{array}$ & $\begin{array}{c}1,2 \\
1,2 \\
1,2 \\
1,2 \\
2\end{array}$ & Water contaminated \\
\hline & $\begin{array}{l}26 \\
27 \\
28 \\
29 \\
30 \\
31\end{array}$ & $\begin{array}{l}140 \\
132 \\
133.5\end{array}$ & $\begin{array}{l}4 \\
4 \\
4 \\
4 \\
4 \\
4\end{array}$ & & $\begin{array}{l}2 \\
2 \\
2 \\
- \\
- \\
2\end{array}$ & $\begin{array}{c}\text { Inactive } \\
\text { Do. } \\
\text { Do. }\end{array}$ \\
\hline
\end{tabular}


Table 8.--Records of we11s that supply water-treatment plants, Venice-Englewood area--Continued

\begin{tabular}{c|c|c|c|c|c|c}
\hline $\begin{array}{c}\text { Location } \\
\text { number }\end{array}$ & $\begin{array}{c}\text { We11 } \\
\text { number }\end{array}$ & $\begin{array}{l}\text { Depth } \\
(\mathrm{ft})\end{array}$ & $\begin{array}{l}\text { Diam- } \\
\text { eter } \\
(\mathrm{in})\end{array}$ & $\begin{array}{l}\text { Casing } \\
\text { depth } \\
(\mathrm{ft})\end{array}$ & $\begin{array}{l}\text { Aquifer } \\
\text { or zone }\end{array}$ & Remarks \\
\hline
\end{tabular}

Venice Gardens 2

Production wells

\begin{tabular}{|c|c|c|c|c|c|}
\hline 1 & 123 & 4 & 47 & 1,2 & Inactive \\
\hline 2 & 130 & 4 & 48 & 1,2 & \\
\hline 3 & 126 & 4 & 50 & 1,2 & Inactive \\
\hline 4 & 124 & 4 & 57 & 1,2 & \\
\hline 5 & 128 & 4 & 49 & 1,2 & Inactive \\
\hline 6 & 127 & 4 & 49 & 1,2 & Do. \\
\hline 7 & 121 & 4 & 63 & 1,2 & \\
\hline 8 & 126 & 4 & 84 & 2 & Inactive \\
\hline 9 & 128 & 4 & 89 & 2 & \\
\hline 10 & 89 & 4 & 63 & 1 & Inactive \\
\hline 11 & 118.5 & 4 & 63 & 1,2 & \\
\hline 12 & 121 & 4 & 68 & 1,2 & Inactive \\
\hline 13 & 126.5 & 4 & 54 & 1,2 & \\
\hline 14 & 125 & 4 & 63 & 1,2 & Inactive \\
\hline 15 & 128 & 4 & 60 & 1,2 & \\
\hline 16 & 121 & 4 & 60 & 1,2 & Inactive \\
\hline 17 & 118 & 4 & 53 & 1,2 & \\
\hline 18 & 129 & 4 & 53 & 1,2 & Inactive \\
\hline 19 & 124 & 4 & 55 & 1,2 & \\
\hline 20 & 127 & 4 & 56 & 1,2 & Inactive \\
\hline 21 & 121 & 4 & 60 & 1,2 & \\
\hline 22 & 125 & 4 & 61 & 1,2 & Inactive \\
\hline 23 & 116 & 4 & 72 & 1,2 & \\
\hline 24 & 129 & 4 & 70 & 1,2 & Inactive \\
\hline 25 & 140.5 & 4 & 60 & 1,2 & \\
\hline 26 & 170 & 4 & 62 & 1,2 & \\
\hline 27 & 98 & 4 & 62 & 1,2 & \\
\hline 28 & 157 & 4 & 60 & 1,2 & \\
\hline 29 & 140 & 6 & 60 & 1,2 & \\
\hline 30 & 140 & 6 & 60 & 1,2 & \\
\hline 31 & 160 & 8 & 42 & 1,2 & Inactive \\
\hline 32 & 169 & 4 & 41 & 1,2 & \\
\hline 33 & 140 & 6 & 60 & 1,2 & \\
\hline 35 & 209 & 8 & 67.5 & 1,2 & Inactive \\
\hline
\end{tabular}

(Data for wells 36 through 40 not available; well 34 not drilled) 
Table 8.--Records of wells that supply water-treatment plants, Venice-Englewood area--Continued

\begin{tabular}{|c|c|c|c|c|c|c|}
\hline $\begin{array}{l}\text { Location } \\
\text { number }\end{array}$ & $\begin{array}{c}\text { We11 } \\
\text { number }\end{array}$ & $\begin{array}{l}\text { Depth } \\
\text { (ft) }\end{array}$ & $\begin{array}{l}\text { Diam- } \\
\text { eter } \\
\text { (in) }\end{array}$ & $\begin{array}{l}\text { Casing } \\
\text { depth } \\
\text { (ft) }\end{array}$ & $\begin{array}{l}\text { Aquifer } \\
\text { or zone }\end{array}$ & Remarks \\
\hline \multicolumn{7}{|c|}{ Venice East Water Plant } \\
\hline \multicolumn{7}{|c|}{ Production wells } \\
\hline 270348082230601 & 1 & 105 & & 45 & 1,2 & \\
\hline 270352082223801 & 2 & 114 & & 63 & 2 & \\
\hline \multirow{21}{*}{270347082225501} & 3 & 110 & & 61 & 2 & \\
\hline & 4 & 120 & 4 & 63 & 2 & \\
\hline & 5 & 146 & 4 & 63 & 2 & \\
\hline & 6 & 120 & 3 & 63 & 2 & \\
\hline & 7 & 118 & 4 & 63 & 2 & \\
\hline & 8 & 116 & 4 & 63 & 2 & \\
\hline & 9 & 141 & 4 & 63 & 2 & \\
\hline & 10 & 120 & 4 & 63 & 2 & \\
\hline & 11 & 119 & 4 & 63 & 2 & \\
\hline & 12 & 139 & 4 & 63 & 2 & \\
\hline & 13 & 104 & 4 & 63 & 2 & \\
\hline & 14 & 90 & 4 & 54.5 & 2 & \\
\hline & 15 & 115 & 4 & 43 & 1,2 & \\
\hline & 16 & 115 & 4 & 52.5 & 1,2 & \\
\hline & 17 & 90 & 4 & 48.5 & 1 & \\
\hline & 18 & 70 & 4 & 54.5 & $\overrightarrow{1}$ & \\
\hline & 19 & 120 & 4 & 56.5 & 1,2 & \\
\hline & 20 & 120 & 4 & 58.5 & 1,2 & \\
\hline & 21 & 120 & 4 & 46 & 1,2 & \\
\hline & 22 & 105 & 4 & 62 & 1,2 & \\
\hline & 23 & 75 & 4 & 60 & 1,2 & \\
\hline \multicolumn{7}{|c|}{ Venice Campground } \\
\hline \multicolumn{7}{|c|}{ Production wel1 } \\
\hline 270553082200801 & 1 & 95 & 4 & 43 & 1,2 & \\
\hline \multicolumn{7}{|c|}{ Venice Ranch } \\
\hline \multicolumn{7}{|c|}{ Production we11s } \\
\hline 270546082234101 & 1 & 79 & 3 & 63 & 2 & \\
\hline 270539082234301 & 2 & 95 & 6 & 60 & 2 & \\
\hline
\end{tabular}

